\title{
Benchmarking South East European Cities with the Sustainable Development of Energy, Water and Environment Systems Index
}

\author{
Şiir Kılkıș \\ The Scientific and Technological Research Council of Turkey (TÜBİTAK), Atatürk Bulvarı No: 221, \\ Kavaklidere 06100, Ankara, Turkey \\ e-mail: siir.kilkis@tubitak.gov.tr
}

Cite as: Kılkış, Ş., Benchmarking South East European Cities with the Sustainable Development of Energy, Water and Environment Systems Index, J. sustain. dev. energy water environ. syst., 6(1), pp 162-209, 2018 , DOI: https://doi.org/10.13044/j.sdewes.d5.0179

\begin{abstract}
Tools that can benchmark cities, including cities in South East Europe, are necessary to enable the comparison and diffusion of more sustainable practices for urban systems. The "Sustainable Development of Energy, Water and Environment Systems Index" provides a composite indicator for benchmarking city performance based on 7 dimensions and 35 main indicators. In this research work, the Index is applied to a new sample of 18 cities in South East Europe for which data is collected, normalized, and aggregated. Klagenfurt (3.08), Velenje (3.06) and Pécs (3.01) are found to be the top three cities in the sample while an average city receives an index score of 2.85 . The results are further compared to reference averages and evaluated based on the mean simulated values of 10,000 Monte Carlo experiments. The results are interpreted in quartiles for pioneering, transitioning, solution-seeking, and challenged cities. The results are then applied within a benchmarking tool of the Index that supports policy learning to trigger collaboration between cities and further used to match cities according to a search algorithm based on index performance. In addition, the results are compared to urban hierarchy as well as development contexts and mapped onto the spatial dimension as an initial step for enabling a "Sustainable Development of Energy, Water and Environment Systems Future City Network". The paper concludes with a set of four proposed steps to enable decision-makers and urban planners in using the Sustainable Development of Energy, Water and Environment Systems Index in support of more sustainable urban systems.
\end{abstract}

\section{KEYWORDS}

Energy, Water, Environment systems, City index, Composite indicator, Urban systems.

\section{INTRODUCTION}

Urban areas are responsible for about $365 \mathrm{EJ}$ or $64 \%$ of global primary energy usage and are liable for $24 \mathrm{Gt}$ of $\mathrm{CO}_{2}$ emissions, which correspond to about $70 \%$ of total Carbon dioxide $\left(\mathrm{CO}_{2}\right)$ emissions from energy-related activities [1]. In a future outlook, baseline scenarios predict that urban primary energy usage may soar to $618 \mathrm{EJ}$ with an increase of $69 \%$ by the year 2050 [1]. However, scenarios that seek to limit global warming to at most $2{ }^{\circ} \mathrm{C}$ indicate that this value may be at most $432 \mathrm{EJ}$ with a maximum increase of $18 \%$ [1]. Under this scenario, the urban share in global $\mathrm{CO}_{2}$ emissions must also be reduced by at least $22 \%$ that will require the elimination of $15.2 \mathrm{Gt} \mathrm{CO}_{2}$ from the baseline 
scenario [1]. Additional scenarios that are in line with the Paris Agreement on Climate Change [2] require values that are well below these projected levels of increases based on a rapid process of decarbonisation using renewable energy resources.

Clearly, urban systems have a central role in enabling the ability to attain a future within planetary thresholds. Urban energy systems define vibrant contexts to address the need to move towards a more sustainable, cleaner, and efficient energy future. At the same time, urban energy systems must be evaluated in a much broader context, including water and environment systems. Hence, the Sustainable Development of Energy, Water and Environment Systems (SDEWES) City Index was developed as an original composite indicator to benchmark city performance [3]. The index has the namesake of the SDEWES Center and Conference series that are dedicated to diffusing knowledge on methods, policies, and technologies for improving the sustainability of development [4]. The composite indicator has since been applied to 58 different cities around the world $[3,5,6]$ as put forth in the website of the SDEWES Center [7]. In this research work, a new sample of 18 cities in South East Europe (SEE) is benchmarked based on the SDEWES Index. The results are used to identify those cities that have performances in certain quartiles as the pioneering, transitioning, solution-seeking, and challenged cities of the sample. The aim of the research work is to present the benchmarking results for the new sample and provide steps that can be used by decision-makers in those cities to improve city performance in the future.

The paper proceeds with a literature review of the existing analyses, tools and solutions to support a more sustainable SEE region. The themes of urban systems for renewable energy, transport, water, waste, and governance are used to exemplify the existing stock of knowledge. In contrast, composite indicators are suitable for combining multiple indicators to benchmark more than one entry in a common framework with numerous other entries. The paper then provides the method of applying the SDEWES Index to enable the systematic benchmarking of 18 cities in the SEE region. The aims of the research work are satisfied based on rankings, a benchmarking tool for cities, and the formulation of city pairs for the present sample. The results are further compared through 10,000 Monte Carlo experiments and evaluated according to contextual factors for urban hierarchy and development. The paper concludes with the implications of these contributions to promote more sustainable urban systems in SEE cities.

\section{SCIENTIFIC SUPPORT FOR A MORE SUSTAINABLE SEE REGION}

Analyses, tools, and solutions to support a more sustainable SEE region have been increasing rapidly. These include studies that provide scientific support for a renewable energy transition in the SEE region [8] and beyond. Among related studies, Duić et al. [9] developed a RenewIslands method to enable islands to plan for the integration of energy and resource flows based on local assets to increase the sustainability of development. The need for smart energy storage to utilize excess electricity production was undertaken by Krajačić et al. [10] to enable an energy system for Croatia that is self-sustainable based on renewable energy. Pukšec et al. [11] modelled the energy demand of Croatia and suggested wedges that could reduce energy demand by $40 \%$ by the year 2050 when compared to the worst case scenario. Komušanac et al. [12] simulated and graded scenarios for the power system of Croatia. A scenario with over $3 \mathrm{GW}$ of wind power and installed PV capacity provided favourable results. Schneider et al. [13] found the possibility of $3 \%$ emission savings based on measures for recovering energy from Municipal Solid Waste (MSW) in Croatia.

In addition, Dedinec et al. [14] identified priorities for realizing the Greenhouse Gas (GHG) emissions target of Macedonia based on renewable energy. Three scenarios with various levels of ambition to reduce $\mathrm{CO}_{2}$ emissions were analysed [15]. Ćosić et al. [16] 
put forth scenarios towards reaching a 100\% Renewable Energy System (RES) for Macedonia in the year 2050. At the regional level, Dominković et al. [17] modelled the energy systems of 11 countries in the SEE region. These models were combined into one energy system to evaluate scenarios that could transform the current reliance on fossil fuels to $100 \%$ renewable energy, including sustainable biomass.

\section{Towards more sustainable urban systems}

Urgent challenges that require pioneering scientific results include the need to make cities and communities smarter [18] and more sustainable [19]. In this context, sustainable cities will be a vital component for a more sustainable SEE region. Figure 1 exemplifies the present status of the stock of knowledge in providing scientific support for more sustainable urban systems within the SEE region. The directional flows in the Sankey diagram of Figure 1 represent contributions to the broader themes of urban renewable energy systems, urban transport systems, urban water systems, urban waste systems, and/or urban governance systems. Some studies and technological solutions address more than one urban theme and underline the need to merge analysis boundaries. At the same time, the application of an integrated approach to benchmark cities within the SEE region with a focus on energy, water and environment systems as applied in this research work can diffuse a systematic outlook to allow cities to seek and develop innovative urban solutions. The same outlook can be used to support a cross-sectoral approach between multiple sectors in cities.
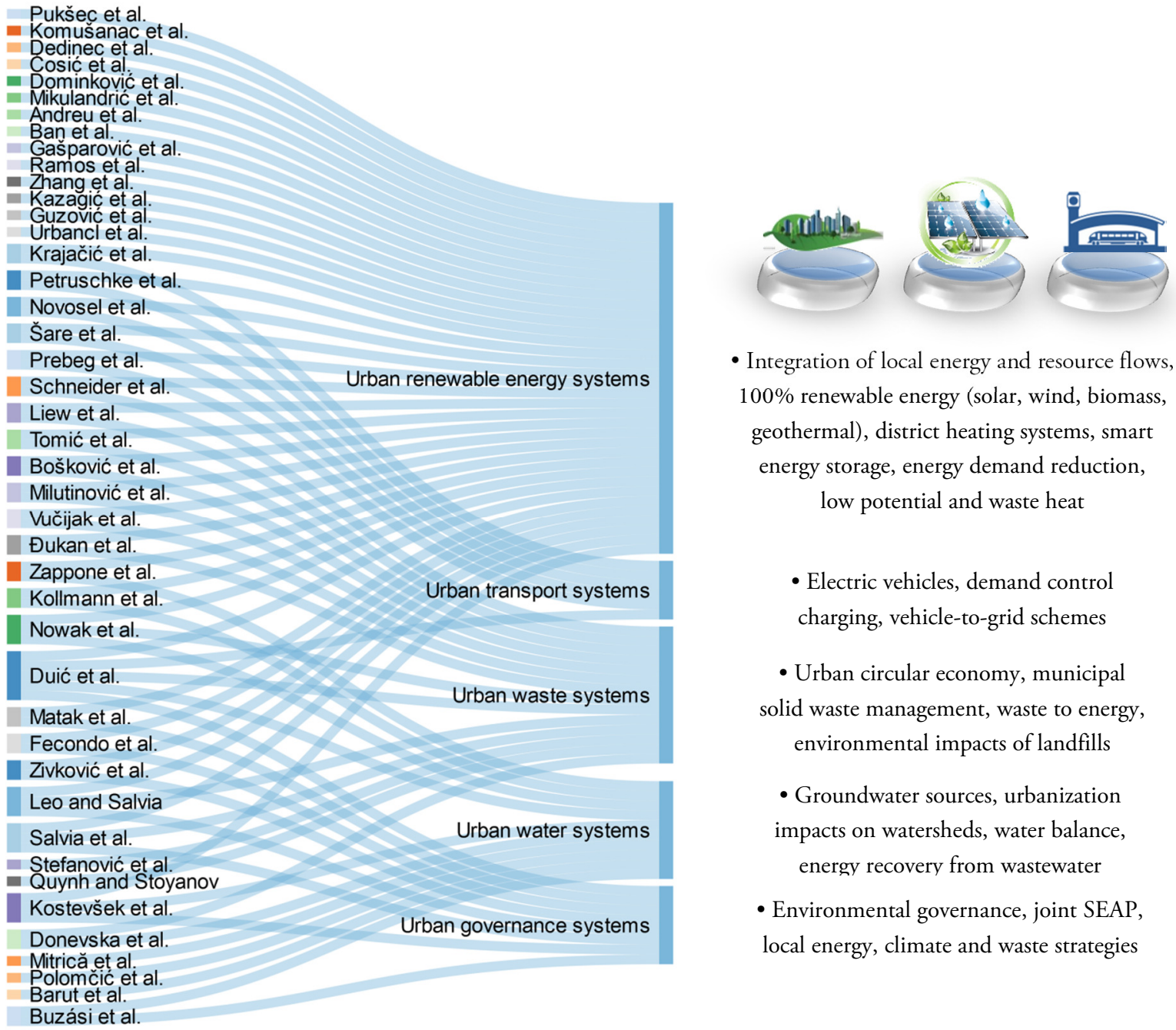

- Integration of local energy and resource flows, $100 \%$ renewable energy (solar, wind, biomass, geothermal), district heating systems, smart energy storage, energy demand reduction, low potential and waste heat

- Electric vehicles, demand control charging, vehicle-to-grid schemes

- Urban circular economy, municipal solid waste management, waste to energy, environmental impacts of landfills

- Groundwater sources, urbanization impacts on watersheds, water balance, energy recovery from wastewater

- Environmental governance, joint SEAP, local energy, climate and waste strategies

Figure 1. Exemplary research contributions to sustainable urban systems in the SEE region 


\section{Analyses of urban renewable energy systems}

As represented in Figure 1, studies at the local level that have an impact on more sustainable urban energy systems include those that are focused on district heating systems. For example, Mikulandrić et al. [20] compared 12 cases for the district heating system of Pokupsko district in Croatia based on heat production costs. Cases that involved renewable energy options were found to provide significant cost advantages. Andreu et al. [21] analysed the potential for upgrading the district heating system of the city of Velika Gorica near Zagreb, Croatia, based on the use of solar energy with pit thermal seasonal storage. In another aspect of energy storage, Ban et al. [22] analysed case studies for the integration of Cool Thermal Energy Storage (CTES) at the building, building cluster, and district cooling system levels at the campus of the University of Zagreb.

The sustainability of a district heating system in Ormož Municipality, Slovenia was assessed by Kostevšek et al. [23] based on the use of various metrics to capture energy-related aspects as well as environmental, social, and economic terms. In a related aspect, Liew et al. [24] reviewed studies that applied total site heat integration to increase the reuse of waste and low potential heat as well as local sources of renewable energy. The authors indicated a need for the integration of industrial, urban and renewable energy systems to enable more efficient local energy sectors.

Other studies emphasized the role of local renewable energy solutions and/or indicated the implications of these solutions for cleaner energy supply to urban areas or islands. Gašparović et al. [25] analysed options to integrate Photovoltaic (PV) panels in campus buildings at the University of Split and the neighbouring vicinity. Ramos et al. [26] compared a set of scenarios based on the area that would be needed for Photovoltaic Thermal (PV-T) collectors in 10 European cities, including Rome and Bucharest. Zhang et al. [27] proposed a hybrid operation of a coal-fired power plant with concentrated solar power in Dubrovnik-Neretva county. Kazagić et al. [28] analysed a typical SEE power system based on a power utility in Sarajevo, Bosnia and Herzegovina and found the possibility of halving $\mathrm{CO}_{2}$ emissions in 2030 under a RES scenario. Moreover, Guzović et al. [29] analysed the proposed application of a system involving an Organic Rankine Cycle (ORC) to utilize the energy and exergy potential of the geothermal field of Velika Ciglena in Croatia. The use of geothermal energy in Slovenia and Serbia was also undertaken by Urbancl et al. [30] for the case of greenhouses. Petruschke et al. [31] combined the RenewIslands method with an optimization approach to reduce the investment costs of a renewable energy solution for Mljet Island in Croatia.

\section{Analyses of urban transport systems}

The interrelation of urban energy and urban transport systems have been another area in which analyses and scenarios have been put forth for the SEE region. For example, Novosel et al. [32] established hourly curves of the transport energy demand of the four largest cities in Croatia to construct a national model to compare scenarios that involved electric vehicles. Šare et al. [33] found that excess electricity production in a future $100 \%$ renewable energy system for the Dubrovnik region could be reduced based on a flexible demand control charging mode for electric vehicles. Prebeg et al. [34] modelled the power system of Croatia between 2015 and 2050, including scenarios for the integration of renewable energy and vehicle-to-grid schemes. Aspects of these studies can support more efficient and renewable energy oriented urban energy systems.

\section{Analyses of water and environment systems supporting South East European cities}

Water and environment systems are other areas of research focus with possible connections to urban energy systems. Zappone et al. [35] analysed the energy usage of 
water and wastewater treatment plants in a metropolitan area in Italy. Polomčić et al. [36] modeled the groundwater sources that provide public water supply to the City of Kikinda, Serbia. Mitrică et al. [37] compared the amount of public water that may be supplied and demanded in scenarios for the Timiş Plain that includes the urban population of Timişoara, Romania. Barut et al. [38] used satellite images to assess the impact of urbanization on temporal variations in a watershed in Turkey. Nowak et al. [39] analyzed two municipal wastewater treatment plants in Austria that are self-sufficient in energy due to the use of Combined Heat and Power (CHP) based on biogas. Kollmann et al. [40] evaluated the wastewater treatment plant of the Austrian town of Freistadt as a local source of energy. Tomić et al. [41] analyzed scenarios to integrate waste to energy schemes in the district heating system of Zagreb to support circular economy at the urban level.

In addition, Donevska et al. [42] assessed the environmental impacts of planned landfills in Macedonia based on the Water Balance Method. Bošković et al. [43] analyzed 51 landfills in Serbia to determine the potential for CHP plants at those sites. Stefanović et al. [44] developed and compared four waste treatment scenarios for the city of Niš (Serbia) in which scenarios for composting and recycling of organic waste were found to have the most favorable outcomes. Milutinović et al. [45] compared two cities in Serbia and Bulgaria, namely the cities of Niš and Sofia, based on scenarios for different waste management systems using multi-criteria analysis. Vučijak et al. [46] applied the VIKOR method to evaluate waste management scenarios for Zavidovici municipality (Bosnia and Herzegovina). The VIKOR method involves the use of a strategy coefficient that represents a compromise between selections of the scenario that excels in the majority of the criteria or a single criterion to better inform decision-making processes.

Beyond the urban core area of cities, Quynh and Stoyanov [47] compared the environmental performance of ports in Bulgaria, including those of Burgas and Varna. Đukan et al. [48] used a bottom-up approach to estimate the biogas production potential in a rural area of Croatia in Gundinci municipality with potential implications for building upon urban-rural linkages.

\section{Analyses of governance and policy formulation in South East European cities}

Governance is a cross-cutting issue for orienting urban energy, water and environment systems towards more sustainable states in the future. Matak et al. [49] put forth and applied an integrated approach to allow small neighboring municipalities on the island of Korčula to prepare joint Sustainable Energy Action Plans (SEAP). Fecondo et al. [50] put forth the results of a mechanism to support technical interventions to increase energy savings in public buildings and lighting armatures in the Province of Chieti, Italy. Zivkovic et al. [51] implemented a participatory approach to enable local stakeholders to define five scenarios for the heating system of the city of Niš, Serbia by the year 2030. Leo and Salvia [52,53] put forth the results of an EU project in which SEE cities developed Local Energy and Waste Strategies. The policy formulation process involved the provision of guidance for energy efficiency, renewable energy, and waste management in 8 SEE cities, including the cities of Nitra and Skopje. Buzási et al. [54] analyzed the $\mathrm{CO}_{2}$ emissions mitigation and climate adaptation measures of Budapest, including those for water management, green areas for flood control, and ventilation corridors.

\section{Policy learning processes in cities as learning organizations}

The vast array of studies that aim to support more sustainable cities in the SEE region as summarized in Figure 1 represent a valuable stock of knowledge. In contrast, barriers to policy learning among cities may still limit the spread and speed of the diffusion of related applications [55]. This limits the ability of cities to identify, learn about and 
implement effective approaches that take place in other cities [56]. Tools that can accelerate the diffusion of knowledge for comparing city performance, thereby increasing opportunities to adopt new solutions, are an urgent need to support SEE cities in their transition towards more sustainable urban systems.

Benchmarking can increase the opportunities that are made available for cities to evaluate present levels of progress relative to other cities and determine areas for further improvement. In particular, cities are learning organizations $[57,58]$ that seek continual improvement, including progress for more sustainable systems [59]. Hirvonen-Kantola et al. [60] had defined two main dynamics that cities utilize in their learning processes. These dynamics, namely exploration and exploitation, require access to new ideas and the use of existing competencies [61]. Marsden et al. [62] found that most cities, however, relied on undertakings on an ad-hoc basis, including scanning visits to other cities, especially in the case of policy learning for urban transport.

\section{Benchmarking opportunities to support a "Science of cities"}

Benchmarking cities based on the systematic use of indicators is vital for stimulating policy learning and providing analytical guidance at the local level. The use of common metrics can also support a "science of cities" to advance an understanding of strengths and weaknesses [63]. Currently, indices to benchmark the social and economic dimensions of city performance represent the most prevalent use of city level indices [63]. In particular, the majority of indices for cities are found to focus on benchmarking the quality of life or the ability of cities to attain economic and business growth [63]. Other indices address digital opportunities [64] as well as issues of safety and security in cities. For example, the Safe Cities Index has provided a benchmarking of 50 cities based on digital security, health security as well as infrastructure and personal safety [65]. In this respect, the gap in the literature for providing analytical support to benchmark urban energy, water and environment systems is addressed with the integrated approach of the SDEWES Index [3, 5-7], which also involves data that is monitored in SEAPs.

Prior to the SDEWES Index, Afgan and da Graça Carvalho [66] developed a General Index of Sustainability to evaluate options for a hybrid energy system for the generation of electricity, heat and/or hydrogen. The authors addressed the utility of multi-criteria methods to support the decision-making process. Lipošćaka et al. [67] applied this framework to compare scenarios for the cogeneration sector in Croatia based on 7 indicators for emissions of exhaust gases and particles, health, and social acceptance, as well as capital investment and fuel costs. Zidanšek et al. [68] undertook analyses of indicators that expressed environmental sustainability, the quality of life and technological development in nations. Positive correlations between quality of life indicators and Gross Domestic Product (GDP) values were found to indicate a possible replacement of the latter.

The footprint method is another branch of benchmarking studies. Galli et al. [69] defined a footprint family based on ecological, carbon and water footprints and proposed its use to track progress towards a One Planet Economy. Most recently, Baabou et al. [70] sought to provide conformity to ecological footprint comparisons at the local level. The method involved the use of monetary multi-regional input-output tables [71] and was applied to 19 coastal cities in the Mediterranean. In another aspect, De Benedetto and Klemeš [72] developed the Environmental Performance Strategy Map that combined the five footprints of carbon, water, energy, emission, and work environment into a single graphical area. The concept was further extended to obtain a Sustainable Environmental Performance Indicator (SEPI) that includes the costs of different options as applied to a plant in the agricultural chemicals sector in Denmark. The possibility of applying the combinatory approach to local communities as well as countries was discussed. 
At the city level, various benchmarking studies were undertaken for world cities mostly outside of the SEE region. For example, Tan et al. [73] developed a framework to define a low-carbon score for cities. Stockholm received the best score among 10 major cities based on aspects including energy, carbon and urban mobility. Other studies focused largely on one domain of sustainable development. Wang et al. [74] compared the energy efficiency of 25 cities with an impact on global economic activity. The authors found that the European cities in the sample were more efficient than those in North America and Asia. Similarly, Hu et al. [75] compared five European and Asian cities to derive policy lessons for techno-social regimes.

In other studies, Deilmann et al. [76] compared the eco-efficiency of 116 cities in Germany based on the ratio of the economic value that was added by the city over the level of environmental damage that was caused. For buildings, Broto et al. [77] evaluated the energy, water usage and GHG emissions of private sector buildings in 40 cities. Van Leeuwen [78] developed a City Blueprint to assess the sustainability of urban water services based on 25 indicators. Mori et al. [79] compared 18 megacities based on 12 indicators for environmental, economic and social power. Wilson [80] put forth 12 indicators to benchmark integrated sustainable waste management practices, which were applied to 5 cities. For urban transport, Ahn et al. [81] benchmarked the energy use intensity of subway stations in Seoul, South Korea.

\section{Aims and rationale of the research work}

This research work aims to apply the SDEWES Index to a new sample of 18 SEE cities to obtain unique benchmarking results. The results are utilized in related analyses so that quartile groupings and city pairings are identified to stimulate collaboration and policy learning between cities. Based on this scope, three interconnected research questions are answered:

- What are the benchmarking results for the present sample according to the SDEWES Index?

- How may the performance of cities be compared based on quartiles and city pairings?

- What may be the policy implications of the SDEWES Index for more integrated urban systems?

A set of four steps is then proposed for decision-makers and urban planners to use the results of the SDEWES Index to trigger policy learning, collaboration and action for more sustainable cities. The results contribute to the literature with benchmarking applications for cities in the sample.

\section{METHOD}

The SDEWES City Index is a composite indicator that provides an integrated approach towards benchmarking the sustainable development of energy, water and environment systems in cities [3, 5-7]. The SDEWES Index is composed of 7 dimensions and 35 main indicators. The first three dimensions are, namely, energy consumption and climate $\left(D_{1}\right)$, penetration of energy and $\mathrm{CO}_{2}$ saving measures $\left(D_{2}\right)$ and renewable energy potential and utilization $\left(D_{3}\right)$. The last four dimensions are water and environmental quality $\left(D_{4}\right), \mathrm{CO}_{2}$ emissions and industrial profile $\left(D_{5}\right)$, city planning and social welfare $\left(D_{6}\right)$, as well as R\&D, innovation and sustainability policy $\left(D_{7}\right)$. The indicators and the results of the previous samples are elaborated in a website of the SDEWES Center that promotes a multidisciplinary approach to sustainability [4].

Previous city samples included 22 Mediterranean port cities [3], 12 SEE cities that consisted mostly of capitals [5] and 25 world cities [6] for an overall total of 58 different cities. In this research work, 18 SEE cities are integrated as a new sample for the 
SDEWES Index. These cities were not benchmarked in any kind of index previously with the exception of four cities that were included in other indices with different scopes and aims as noted in the footnote of Table 1. In addition, Tapia et al. [82] found that cities with relatively high to medium sensitivities to climate vulnerabilities included Rome and Budapest for the impact of heat waves on human health. The same cities further took place among cities that had vulnerabilities to pluvial and fluvial floods as well as the impact of droughts on water planning. Varna also had similar sensitivities to drought as well as the impact of pluvial and coastal flooding on the urban fabric.

\section{Determination of the city sample}

The determination of the city sample is based on a two-phased approach as a variant of multi-stage cluster sampling. In the first phase, an initial set of cities is constructed to represent the widest array of possibilities based on the most populated cities in each country of the SEE region. The SEE region includes the area that is bounded by the countries of Austria and Slovakia in the north and circumscribed by Italy, Greece, Bulgaria and Romania [83]. Turkey is also evaluated in the SEE region [84]. In the second phase, two selection criteria are used to scale-down the initial set to a practical size. First, as a criterion of data availability, cities are required to have a SEAP or an equivalent plan and/or energy statistic. Second, cities that were included in previous samples are directly excluded so that 27 cities to which the SDEWES Index has been applied [3, 5-7] are eliminated*. Lastly, the municipality of Izola that is closest to the town of Piran as the venue of the $2^{\text {nd }}$ SEE SDEWES Conference [85] is added to increase opportunities for policy learning. Table 1 provides the 18 cities in the new sample along with the main references for the cities [86-108].

Table 1. Cities in the sample and references for SEAP or equivalent plan

\begin{tabular}{|c|c|c|c|c|c|}
\hline City & $C_{j}$ & Country & SEAP & Other plan & Reference \\
\hline Bijeljina & $C_{1}$ & Bosnia and Herzegovina & $\checkmark$ & & [86] \\
\hline Braşov & $C_{2}$ & Romania & $\checkmark$ & & [87] \\
\hline Bratislava $^{a}$ & $C_{3}$ & Slovakia & $\checkmark$ & & [88] \\
\hline Budapest $^{\mathrm{a}}$ & $C_{4}$ & Hungary & $\checkmark$ & & {$[89,90]$} \\
\hline Burgas & $C_{5}$ & Bulgaria & $\checkmark$ & & [91] \\
\hline Bursa Nilüfer & $C_{6}$ & Turkey & $\checkmark$ & & [92] \\
\hline Celje & $C_{7}$ & Slovenia & $\checkmark$ & & [93] \\
\hline Izola & $C_{8}$ & Slovenia & & $\checkmark$ & [94] \\
\hline Klagenfurt & $C_{9}$ & Austria & $\checkmark$ & & [95] \\
\hline Kranj & $C_{10}$ & Slovenia & $\checkmark$ & & [96] \\
\hline Nitra & $C_{11}$ & Slovakia & $\checkmark$ & & {$[97,98]$} \\
\hline Osijek & $C_{12}$ & Croatia & $\checkmark$ & & {$[99,100]$} \\
\hline Pécs & $C_{13}$ & Hungary & $\checkmark$ & & [101] \\
\hline Rome $^{\mathrm{a}}$ & $C_{14}$ & Italy & $\checkmark$ & & [102] \\
\hline Turin $^{a}$ & $C_{15}$ & Italy & $\checkmark$ & & [103-105] \\
\hline Varna & $C_{16}$ & Bulgaria & $\checkmark$ & & [106] \\
\hline Velenje & $C_{17}$ & Slovenia & $\checkmark$ & & [107] \\
\hline Zenica & $C_{18}$ & Bosnia and Herzegovina & $\checkmark$ & & [108] \\
\hline
\end{tabular}

\section{Data collection for implementation}

Data sources for indices can rely on available data at the local, national or international level [63]. The application of the SDEWES Index to the 18 SEE cities required an extensive process of data collection from multiple sources. SEAPs that are prepared under the Covenant of Mayors (CoM) initiative [109] and monitoring reports

\footnotetext{
* Athens, Bari, Belgrade, Bucharest, Cluj-Napoca, Eskişehir, Heraklion, İstanbul, Ljubljana, Maribor, Milan, Naples, Niš, Patras, Podgorica, Pula, Rijeka, Sarajevo, Skopje, Sofia, Thessaloniki, Timișoara, Tirana, Vienna, Volos, Zadar, Zagreb
} 
[110], including those that may be given in the context of the updated Global Covenant of Mayors for Climate and Energy [111], provided the basis to evaluate energy and $\mathrm{CO}_{2}$ emissions related data and the set of measures for most cities. The CoM initiative represents the leading policy framework for climate mitigation in which signatories have already achieved an overall reduction of $23 \%$ in $\mathrm{CO}_{2}$ emissions from baseline years [112]. Such a reduction received the greatest contribution from the building sector. In addition, while $7 \%$ of $\mathrm{CoM}$ signatories also had climate adaptation targets previously [112], the total number of signatories in the new framework has since surpassed 7,500 signatories [111]. Hence, the share of cities that have or will approve both kinds of climate action is increasing.

Table 1 provides the references for the SEAPs, the most recent monitoring reports, and/or equivalent plans. Moreover, Sustainable Energy and Climate Action Plans (SECAP) are expected to extend to climate hazards, such as extreme weather events and related adaptation actions [113]. Table 2 summarizes the data sources for all indicators in the SDEWES Index. These include datasets from the United Nations, World Health Organization and the European Environment Agency. Databases based on geographic information systems were also deployed, such as those of the Joint Research Center and International Union for Conservation of Nature.

Table 2. Dimensions and indicators of the SDEWES Index

\begin{tabular}{|c|c|c|c|c|}
\hline Dimension & Indicator $\left(i_{x . y}\right)$ & Unit & Source & Direction \\
\hline \multirow{5}{*}{$D_{1}$} & 1.1. Energy consumption of buildings & [MWh] & SEAP $^{\mathrm{a}}$ & $\downarrow$ \\
\hline & 1.2. Energy consumption of transport & [MWh] & SEAPa & $\downarrow$ \\
\hline & 1.3. Energy consumption per capita & [MWh] & Calculated & $\downarrow$ \\
\hline & 1.4. Heating Degree-Days (HDD) & [Days $\left.{ }^{\circ} \mathrm{C}\right]$ & [114] & $\uparrow$ \\
\hline & 1.5. Cooling Degree-Days (CDD) & [Days ${ }^{\circ} \mathrm{C}$ ] & [115] & $\uparrow$ \\
\hline \multirow{5}{*}{$D_{2}$} & 2.1. Sustainable Energy Action Plan (SEAP) & Dimensionless & Table 4 & $\uparrow$ \\
\hline & 2.2. Combined heat and power based $\mathrm{DH} / \mathrm{C}$ & Dimensionless & Table 4 & $\uparrow$ \\
\hline & 2.3. Energy savings in end-usage (buildings) & Dimensionless & Table 4 & $\uparrow$ \\
\hline & 2.4. Density of public transport network & Dimensionless & Table 4 & $\uparrow$ \\
\hline & 2.5. Efficient public lighting armatures & Dimensionless & Table 4 & $\uparrow$ \\
\hline \multirow{5}{*}{$D_{3}$} & 3.1. Solar energy potential & {$\left[\mathrm{Wh} / \mathrm{m}^{2} /\right.$ day $]$} & {$[116]$} & $\bar{\uparrow}$ \\
\hline & 3.2. Wind energy potential & {$[\mathrm{m} / \mathrm{s}]$} & {$[116,117]$} & $\uparrow$ \\
\hline & 3.3. Geothermal energy potential & {$\left[\mathrm{mW} / \mathrm{m}^{2}\right]$} & {$[117,118]$} & $\uparrow$ \\
\hline & 3.4. Renewable energy in electricity production & Dimensionless & Table $5^{\text {b }}$ & $\uparrow$ \\
\hline & 3.5. Biofuel share in transport energy usage & Dimensionless & Table $5^{\mathrm{b}}$ & $\uparrow$ \\
\hline \multirow{5}{*}{$D_{4}$} & 4.1. Domestic water consumption per capita & {$\left[\mathrm{m}^{3} /\right.$ year $]$} & See note ${ }^{\mathrm{c}}$ & $\downarrow$ \\
\hline & 4.2. Water quality index $(/ 100)$ & Dimensionless & {$[119,120]$} & $\uparrow$ \\
\hline & 4.3. Annual mean $\mathrm{PM}_{10}$ concentration & {$\left[\mu \mathrm{g} / \mathrm{m}^{3}\right]$} & {$[121,122]$} & $\downarrow$ \\
\hline & 4.4. Ecological footprint per capita & [gha] & {$[71,123]$} & $\downarrow$ \\
\hline & 4.5. Biocapacity per capita & [gha] & {$[123]$} & $\uparrow$ \\
\hline \multirow{5}{*}{$D_{5}$} & 5.1. $\mathrm{CO}_{2}$ emissions of buildings & {$\left[\mathrm{tCO}_{2}\right]$} & SEAP $^{a}$ & $\downarrow$ \\
\hline & 5.2. $\mathrm{CO}_{2}$ emissions of transport & {$\left[\mathrm{tCO}_{2}\right]$} & SEAP $^{\mathrm{a}}$ & $\downarrow$ \\
\hline & 5.3. Average $\mathrm{CO}_{2}$ intensity & {$\left[\mathrm{t} \mathrm{CO}_{2} / \mathrm{MWh}\right]$} & Calculated & $\downarrow$ \\
\hline & 5.4. Number of $\mathrm{CO}_{2}$ intense industries & Dimensionless & Table 7 & $\downarrow$ \\
\hline & 5.5. Airport ACA level $(0,1,2,3)$ & Dimensionless & {$[124]$} & $\uparrow$ \\
\hline \multirow{5}{*}{$D_{6}$} & 6.1. Accessibility of public transport & Dimensionless & Table 8 & $\downarrow$ \\
\hline & 6.2. Urban form and municipal management & Dimensionless & Table 8 & $\uparrow$ \\
\hline & 6.3. Gross domestic product per capita & PPP\$ national & {$[125]$} & $\uparrow$ \\
\hline & 6.4. Inequality adjusted well-being & Dimensionless & [126] & $\uparrow$ \\
\hline & 6.5. Tertiary education rate & Dimensionless & [127] & $\uparrow$ \\
\hline \multirow{5}{*}{$D_{7}$} & 7.1. R\&D and innovation policy orientation & Dimensionless & Table 9 & $\bar{\uparrow}$ \\
\hline & 7.2. National patents in clean technologies & Dimensionless & {$[128]$} & $\uparrow$ \\
\hline & 7.3. Local public/private universities & Dimensionless & Table 9 & $\uparrow$ \\
\hline & 7.4. National $h$-index (citations per paper) & Dimensionless & {$[129]$} & $\uparrow$ \\
\hline & 7.5. Reduction target for $\mathrm{CO}_{2}$ emissions & Dimensionless & SEAPa & $\uparrow$ \\
\hline
\end{tabular}

Calculated from SEAP or equivalent plans and statistics as referenced in Table 1

${ }^{6}$ Calculated based on the share of renewable energy in the energy mix from IEA statistics [130]

References are based on the water footprint [131-133]

\section{Normalized value aggregation for the composite index}

The data entries for each indicator are normalized based on the Min-Max method [134] according to the desired direction of change in either increasing $(\uparrow)$ or decreasing $(\downarrow)$ functions. Eq. (1) provides the means of aggregating the normalized values of the data 
entries into a composite index value per city $C_{j}$. Here, $I_{x . y}$ is the normalized value of the $y^{\text {th }}$ indicator in dimension $x$ for a given city $C_{j}$, which represents a process that is reiterated for all data entries $i_{x . y}$. Accordingly, the double summation in eq. (1) sums the normalized values $I_{x . y}$ of indicators $y=1$ to $y=5$ (inner summation) in all dimensions $x=1$ to $x=7$ for 35 indicators:

$$
\operatorname{SDEWES}\left(C_{j}\right)=\left[\sum_{x=1}^{7} \sum_{y=1}^{5} \alpha_{x} I_{x . y}\left(C_{j}\right)\right] \text { where } \sum_{x=1}^{7} \alpha_{x}=1
$$

The results of eq. (1) for each dimension are analysed in dimension rankings and performance quartiles. Moreover, the normalized dimension values for cities $C_{j}$ are compared with those for the sample average $\left(C_{A V}\right)$ based on the ratios in eq. (2). In addition, eq. (3) is used to determine the percentage difference of the aggregated index value for cities $C_{j}$ with the aggregated index value for $C_{A V}$, which are integrated into the presentation of the results:

$$
\begin{gathered}
D_{x}\left(C_{j}\right) / D_{x}\left(C_{A V}\right)=\sum_{y=1}^{5}\left[I_{x . y}\left(C_{j}\right) / I_{x . y}\left(C_{A V}\right)\right] \text { for } x=\{1,2, \ldots 7\} \\
\operatorname{SDEWES}\left[\left(C_{j}-C_{A V}\right) / C_{A V}\right]=\sum_{x=1}^{7} \sum_{y=1}^{5} \alpha_{x}\left\{\left[I_{x . y}\left(C_{j}\right)-I_{x . y}\left(C_{A V}\right)\right] / I_{x . y}\left(C_{A V}\right)\right\}
\end{gathered}
$$

In eq. (1), all dimensions have five indicators and may be weighted equally. In this case, dimension weights $\alpha_{x}$ will be 0.14 . In practice, $\alpha_{x}$ is 0.22 for $D_{1}$ and $D_{5}$ that directly involve energy and $\mathrm{CO}_{2}$ emissions data from SEAP. For other dimensions that may indirectly relate to SEAP data, the values of $\alpha_{x}$ are 0.11 . As indicated in the condition of eq. (1), the sum of dimension weights $\alpha_{x}$ is equal to unity and the maximum aggregated index value that is possible is 5 . Weights $\alpha_{x . y}$ may also be differentiated for each indicator. In this research work, the sensitivity of the SDEWES Index to random weights $\alpha_{x . y}$ is evaluated based on 10,000 Monte Carlo experiments that are applied to the normalized values of the indicators in eq. (1). Any changes in rank are assessed based on the mean simulated values of the experiments.

\section{Determination of city performance quartiles}

Overall, the mean simulated values of the Monte Carlo experiments are used to determine cities that perform in certain quartiles. The cities that are in $Q_{4}$ at the top $25^{\text {th }}$ percentile are termed as "pioneering" SDEWES cities based on a high level of performance in multiple dimensions. Those cities that put forth noteworthy efforts towards obtaining above median performances but may have certain shortcomings take place in the next quartile $\left(Q_{3}\right)$ as the "transitioning" SDEWES cities. Cities in $Q_{3}$ have a standing in the top $50 \%$ but below the top $25 \%$. In contrast, those cities that are faced with greater challenges in attaining more sustainable urban systems are termed as "solution-seeking" $\left(Q_{2}\right)$ and "challenged" $\left(Q_{1}\right)$ SDEWES cities. The results are not to be seen as static but those that may be changed across time in a dynamic approach, particularly through city-to-city collaboration for more integrated urban systems.

\section{City pairings and pattern identification}

One of the aims of the SDEWES Index is to stimulate collaboration among cities, which is further supported based on city pairings. In this context, the performance of cities is subjugated to a search algorithm to identify those cities that may have similar 
levels of performance in each dimension of the Index when compared to the average. Eq. (4) indicates the condition for the search algorithm [6]. For each dimension $D_{x}$, the summation of the normalized values of the indicators $I_{x . y}$ for a city $C_{j}$ is tested for being greater than or equal to the average value of the summation for an average city of the overall sample $\left(C_{A V 2}\right)$. Any given city pair $P$ has to be either above or below the average in the same dimension across all dimensions $D_{1}$ to $D_{7}$. This condition is tested in a $76 \times 76$ matrix that includes over 4,000 different combinations. The process can support twinning cities [135] based on the SDEWES Index, including peer cities:

$$
\sum_{y=1}^{5} I_{x . y}\left(C_{j}\right) \geq \sum_{y=1}^{5} I_{x . y}\left(C_{A V 2}\right) \text { for } x=\{1,2, \ldots 7\}
$$

\section{Comparison of the results to contextual factors}

Rather than a single indicator, Table 2 requires a high level of performance across a gamut of indicators and dimensions for cleaner energy, better environmental quality, as well as social welfare. In this respect, all cities need to explore the means of obtaining a more efficient and cleaner status in the context of distinct urban realities. For this reason, the benchmarking results of the SDEWES Index for the present sample of 18 SEE cities and any cities in the city pairs are compared to broader contextual factors. Such contextual factors are assessed based on urban hierarchy according to population [136] and the development of the country in which the city is located. Other factors include the set of local characteristics, opportunities, and concerns [137].

\section{Benchmarking tool and the Sustainable Development of Energy, Water and Environment Systems City Atlas}

An interface that is based on the SDEWES Index was proposed to enable the benchmarking of multiple cities in reference [6]. This proposal, namely, the SDEWES Index Benchmarking Tool for Policy Learning, is applied to the results for the present sample of 18 SEE cities. The Tool can be used to support at least two typologies of policy learning. Cities with differing performances can trigger processes of exploration so that a city with a lower ranking may identify ways to reach a better ranking in any component of the index [6]. Cities with similar performances can be matched to exploit ways to address needs, problems, and/or goals jointly.

Moreover, a SDEWES Index Atlas is developed for the first time in which the results for the city sample are mapped onto the spatial dimension to compare levels of urban performance. The atlas may also be used to support a future city network for which exemplary policy implications are put forth. It is expected that both tools will increase the ease with which the results are used by urban planners and decision-makers to improve the relative sustainability of their cities.

\section{SUSTAINABLE DEVELOPMENT OF ENERGY, WATER AND ENVIRONMENT SYSTEMS INDEX APPLICATION}

This section summarizes the application of the 35 main indicators of the SDEWES Index to the new sample of $18 \mathrm{SEE}$ cities. Based on original data compilations, 630 data inputs were collected for the 35 main indicators (Tables 3-9). With sub-indicators, about 990 data entries were involved. Appendix A provides the data for the sub-indicators as supplementary material.

\section{Energy consumption and climate $\left(D_{1}\right)$}

Table 3 provides the data inputs for the 18 SEE cities based on the indicators in $D_{1}$. In an average city, the building and transport sectors consume 4,371,710 $\mathrm{MWh}$ and 
1,765,674 MWh of energy per year, respectively, which are reducing in the context of SEAPs. The realization of such reductions requires more efficient solutions as well as precautions against short and long term rebound effects [138] that may partially reduce or offset energy savings. Some cities have implemented measures for efficiency gains and user behaviour mostly on the demand side. On average, the total final energy use per capita is $13.52 \mathrm{MWh}$. Energy per capita values are known to vary according to affluence, urban density, climate and proximity to public transport, among a multiplicity of other factors [139]. In the sample, the lowest value is 6.42 MWh (Varna) and the highest value is $22.91 \mathrm{MWh}$ (Kranj) per capita. As other indicators in $D_{1}$, Heating Degree Days (HDD) and Cooling Degree Days (CDD) are useful to adjust energy consumption with climate. The average HDD is 3,063 and average CDD is 1,494. Based on international climate zone definitions [140], 10 cities fall within the 5A, 5B, and 5C climate zones with $3,000<\mathrm{HDD} \leq 4,000$, which is followed by the $4 \mathrm{~A}$ and $4 \mathrm{~B}$ climate zones (CDD $\leq 2,500$ and HDD $\leq 3,000$ ). The cities on the extreme end of HDD or CDD are Klagenfurt, Kranj, and Rome, respectively.

Table 3. Data inputs to the energy consumption and climate dimension $\left(D_{1}\right)$

\begin{tabular}{cccccc}
\hline City $\left(C_{j}\right)$ & $\begin{array}{c}\text { Energy } \\
\text { consumption } \\
\text { of buildings } \\
{[\mathrm{MWh}]^{\mathrm{a}}}\end{array}$ & $\begin{array}{c}\text { Energy consumption } \\
\text { of transport [MWh] }^{\mathrm{a}}\end{array}$ & $\begin{array}{c}\text { Total energy } \\
\text { consumption per } \\
\text { capita }[\mathrm{MWh}]^{\mathrm{a}}\end{array}$ & HDD $^{\mathrm{b}}$ & CDD \\
\hline Bijeljina & $1,405,280$ & 329,821 & 11.37 & 2,987 & 1,534 \\
Brașov & $1,919,368$ & 606,006 & 9.34 & 3,778 & 1,232 \\
Bratislava & $6,854,194$ & $3,131,796$ & 21.46 & 3,210 & 1,360 \\
Budapest & $21,723,238$ & $6,274,839$ & 15.93 & 2,834 & 1,670 \\
Burgas & $2,190,589$ & 208,788 & 11.30 & 2,269 & 2,052 \\
Bursa Nilüfer & $1,696,110$ & $1,057,446$ & 7.93 & 2,270 & 1,903 \\
Celje & 303,984 & 370,050 & 13.87 & 3,542 & 1,165 \\
Izola & 133,032 & 60,009 & 12.27 & 3,075 & 1,386 \\
Klagenfurt & $1,333,847$ & 592,025 & 19.93 & 4,028 & 918 \\
Kranj & 968,445 & 250,687 & 22.91 & 4,028 & 918 \\
Nitra & 628,329 & 349,977 & 12.20 & 3,337 & 1,267 \\
Osijek & $1,427,712$ & 226,987 & 15.35 & 2,607 & 1,813 \\
Pécs & $1,637,687$ & 362,109 & 12.75 & 2,564 & 1,877 \\
Rome & $23,503,569$ & $14,459,000$ & 14.03 & 1,201 & 2,528 \\
Turin & $10,563,000$ & $2,783,000$ & 14.95 & 4,254 & 718 \\
Varna & $1,373,506$ & 552,000 & 6.42 & 2,471 & 2,001 \\
Velenje & 400,302 & 61,196 & 13.90 & 3,542 & 1,165 \\
Zenica & 628,580 & 106,391 & 7.39 & 3,130 & 1,380 \\
\hline Average & $4,371,710$ & $1,765,674$ & 13.52 & 3,063 & 1,494 \\
\hline abtained or calculated from SEAP or equivalent plans based on the references in Table 1 & & \\
b Based on temperature differences with the base value of $18{ }^{\circ} \mathrm{C}$ for each day over the heating period &
\end{tabular}

\section{Penetration of energy and carbon dioxide saving measures $\left(\mathrm{D}_{2}\right)$}

Table 4 provides the data inputs into the indicators in $D_{2}$. All SEE cities in the sample are in the process of implementing SEAP measures or equivalent strategies to increase primary energy savings. In Table 4, cities with CHP based District Heating and Cooling (DHC) networks are further distinguished from those cities that have individual Heat Only Boilers (HOB) or only district heating. Table A1 in supplementary material provides details on the energy system characteristics. Energy systems that involve the utilization of renewable energy have central roles in enabling more sustainable urban systems. In a future outlook, some cities can be seen to have developments towards the initiation of fourth generation $(4 \mathrm{G})$ district heating networks. These networks have lower 
supply temperatures and higher efficiencies based on multiple sources [141, 142]. Bijeljina is evaluating the utilization of geothermal energy [86] and Izola has proposals to benefit from sea water for district cooling in a local future energy concept [94].

In addition, almost all cities are located in countries with national level plans for nearly Zero Energy Buildings (nZEB). The cities that have implementations of nZEB, energy-plus buildings, carbon neutral buildings and/or districts are scored accordingly. The details of nZEB related developments are given in Table A2. In other aspects of $D_{2}$, Budapest $(157 \mathrm{~km})$ and Rome $(60 \mathrm{~km})$ have the tramway and subway with the longest length, respectively (see Table A3). Based on the use of an additional sub-indicator, the density of public transport is evaluated relative to the urban area. Turin $\left(0.75 \mathrm{~km} / \mathrm{km}^{2}\right)$ and Budapest $\left(0.37 \mathrm{~km} / \mathrm{km}^{2}\right)$ have the densest schemes.

Cities with best practices in implementing efficient public lighting measures are as provided in Table 4. These include Budapest that implemented a self-sustaining public lighting system $[143,144]$. Other cities improved electricity usage per light pole among which Braşov reduced this value to $550 \mathrm{kWh}$ per light pole [145] and Klagenfurt saved $16 \mathrm{MWh}$ per year [146].

Table 4. Data inputs to the penetration of energy and $\mathrm{CO}_{2}$ measures dimension $\left(D_{2}\right)$

\begin{tabular}{|c|c|c|c|c|c|}
\hline City $\left(C_{j}\right)$ & SEAP $^{a}$ & $\begin{array}{c}\text { Combined } \\
\text { heat and } \\
\text { power } \\
\text { based } \mathrm{DH} / \mathrm{C}^{\mathrm{b}}\end{array}$ & $\begin{array}{l}\text { Energy savings } \\
\text { in end-usage } \\
\text { (buildings) }^{c}\end{array}$ & $\begin{array}{l}\text { Density of } \\
\text { public transport } \\
\text { network }^{\mathrm{d}}\end{array}$ & $\begin{array}{l}\text { Efficient public } \\
\text { lighting armatures }\end{array}$ \\
\hline Bijeljina & 2.0 & 1 & 1 & 1 & 1 \\
\hline Braşov & 2.0 & 2 & 1 & 1 & 1 \\
\hline Bratislava & 2.0 & 2 & 2 & 4 & 1 \\
\hline Budapest & 2.0 & 2 & 2 & 5 & 2 \\
\hline Burgas & 2.0 & 2 & 1 & 1 & 2 \\
\hline Bursa Nilüfer & 2.0 & 0 & 1 & 3 & 1 \\
\hline Celje & 2.0 & 2 & 1 & 1 & 1 \\
\hline Izola & 1.0 & 1 & 1 & 1 & 2 \\
\hline Klagenfurt & 2.0 & 2 & 2 & 1 & 1 \\
\hline Kranj & 2.0 & 1 & 1 & 1 & 1 \\
\hline Nitra & 2.0 & 2 & 1 & 1 & 1 \\
\hline Osijek & 2.0 & 2 & 2 & 3 & 1 \\
\hline Pécs & 2.0 & 2 & 2 & 3 & 1 \\
\hline Rome & 2.0 & 1 & 2 & 4 & 1 \\
\hline Turin & 2.0 & 2 & 2 & 6 & 1 \\
\hline Varna & 2.0 & 2 & 1 & 1 & 2 \\
\hline Velenje & 2.0 & 2 & 1 & 1 & 2 \\
\hline Zenica & 2.0 & 1 & 1 & 1 & 1 \\
\hline Average & 1.9 & 1.6 & 1.4 & 2.2 & 1.3 \\
\hline
\end{tabular}

\section{Renewable energy potential and utilization $\left(D_{3}\right)$}

Table 5 provides the data inputs for the indicators in $D_{3}$. An average city in the sample has $4,286 \mathrm{Wh} / \mathrm{m}^{2}$ of solar energy potential per day on an optimally inclined plane. The average wind energy potential is $4.4 \mathrm{~m} / \mathrm{s}$ at 50 meters above the ground. For geothermal energy, Bijeljina has the greatest mean heat-flow density of about $86 \mathrm{~mW} / \mathrm{m}^{2}$ while the average is $66 \mathrm{~mW} / \mathrm{m}^{2}$. The city is considering the use of geothermal wells to supply the district heating system [147]. The average share of renewable energy 
in electricity production is $32.9 \%$ with a dominant contribution from hydropower. The highest share is 78\% (Klagenfurt) and the lowest share is 10\% (Budapest and Pécs). Based on calculations of biofuels in the transport sector, six cities obtained at least a 4\% share of biofuels in the transport sector. The highest in the sample is 5.9\% (Klagenfurt). An additional four cities are above the average share value of $3.2 \%$.

Table 5. Data inputs to the renewable energy potential and utilization dimension $\left(D_{3}\right)$

\begin{tabular}{|c|c|c|c|c|c|}
\hline City $\left(C_{j}\right)$ & $\begin{array}{c}\text { Solar energy } \\
\text { potential } \\
{\left[\mathrm{Wh} / \mathrm{m}^{2} / \text { day }\right]^{\mathrm{a}}}\end{array}$ & $\begin{array}{c}\text { Wind energy } \\
\text { potential } \\
{[\mathrm{m} / \mathrm{s}]^{\mathrm{a}}}\end{array}$ & $\begin{array}{c}\text { Geothermal } \\
\text { energy } \\
\text { potential } \\
{\left[\mathrm{mW} / \mathrm{m}^{2}\right]^{\mathrm{b}}}\end{array}$ & $\begin{array}{c}\text { Renewable } \\
\text { energy in } \\
\text { electricity } \\
\text { production }[\%]^{\mathrm{c}}\end{array}$ & $\begin{array}{c}\text { Biofuel share } \\
\text { in transport } \\
{[\%]^{\mathrm{d}}}\end{array}$ \\
\hline Bijeljina & 4,210 & 4.8 & 86 & 41 & 0.0 \\
\hline Braşov & 3,870 & 4.0 & 56 & 34 & 4.0 \\
\hline Bratislava & 3,950 & 5.0 & 65 & 22 & 4.3 \\
\hline Budapest & 3,890 & 4.3 & 80 & 10 & 4.0 \\
\hline Burgas & 4,590 & 5.9 & 40 & 17 & 3.8 \\
\hline Bursa Nilüfer & 4,760 & 4.9 & 80 & 29 & 2.0 \\
\hline Celje & 4,080 & 4.1 & 76 & 32 & 3.2 \\
\hline Izola & 4,670 & 4.5 & 40 & 32 & 3.2 \\
\hline Klagenfurt & 4,160 & 3.9 & 65 & 78 & 5.9 \\
\hline Kranj & 4,010 & 4.0 & 65 & 32 & 3.2 \\
\hline Nitra & 3,950 & 5.0 & 65 & 22 & 4.3 \\
\hline Osijek & 4,220 & 4.5 & 86 & 65 & 1.6 \\
\hline Pécs & 4,170 & 4.6 & 86 & 10 & 4.0 \\
\hline Rome & 5,300 & 3.9 & 65 & 39 & 3.5 \\
\hline Turin & 4,730 & 3.0 & 65 & 39 & 3.5 \\
\hline Varna & 4,570 & 5.3 & 40 & 17 & 3.8 \\
\hline Velenje & 3,980 & 3.8 & 65 & 32 & 3.2 \\
\hline Zenica & 4,040 & 4.2 & 65 & 41 & 0.0 \\
\hline Average & 4,286 & 4.4 & 66 & 32.9 & 3.2 \\
\hline
\end{tabular}

\section{Water and environmental quality $\left(\mathrm{D}_{4}\right)$}

Table 6 provides the data inputs into the indicators in $D_{4}$. The average ground and surface water that is consumed per capita is $10.1 \mathrm{~m}^{3}$ per year based on the water footprint method [132, 133]. On average, water quality is scored to be 88.3 out of 100 based on levels of dissolved oxygen, $\mathrm{pH}$, conductivity and nutrients of nitrogen and phosphorus. Annual mean concentrations of $\mathrm{PM}_{10}$ in urban traffic contexts are $31.7 \mu \mathrm{g} / \mathrm{m}^{3}$ in which the lowest value is $19.9 \mu \mathrm{g} / \mathrm{m}^{3}$ (Izola) and the highest value is $69.8 \mu \mathrm{g} / \mathrm{m}^{3}$ (Zenica) where the latter includes impact from the local industry. Velenje closely follows Izola for the lowest annual mean concentration of $\mathrm{PM}_{10}$ at $21.0 \mu \mathrm{g} / \mathrm{m}^{3}$. The average ecological footprint per capita is 4.2 global hectares (gha), which quantifies the demand for land across six categories, including built-up land, land for various agricultural produce and land to uptake $\mathrm{CO}_{2}$ emissions from human activities [148]. In contrast, biocapacity per capita is 2.2 gha, indicating an ecological deficit of 2.0 gha per capita. In comparison, ecological footprint per capita in Rome deviates by about $5 \%$ from the national value and represents $7 \%$ of the total ecological footprint of Italy [70]. Similar instances indicate that cities have double dynamics based on trade-offs between investments to improve eco-efficiency and citizens who may have higher resource use due to urban lifestyles 
[70]. The world average is an ecological footprint of 2.7 gha and biocapacity of 1.8 gha per capita [123].

Table 6. Data inputs to the water and environmental quality dimension $\left(D_{4}\right)$

\begin{tabular}{|c|c|c|c|c|c|}
\hline City $\left(C_{j}\right)$ & $\begin{array}{c}\text { Domestic water } \\
\text { consumption per } \\
\text { capita }\left[\mathrm{m}^{3}\right]\end{array}$ & $\begin{array}{l}\text { Water quality } \\
\text { index }[/ 100]^{\mathrm{a}}\end{array}$ & $\begin{array}{c}\text { Average air } \\
\text { quality } \mathrm{PM}_{10} \\
{\left[\mu \mathrm{g} / \mathrm{m}^{3}\right]^{\mathrm{b}}}\end{array}$ & $\begin{array}{l}\text { Ecological } \\
\text { footprint per } \\
\text { capita [gha] } \\
\end{array}$ & $\begin{array}{c}\text { Biocapacity } \\
\text { per capita } \\
\text { [gha] }\end{array}$ \\
\hline Bijeljina & 10.5 & 90.9 & 22.6 & 3.1 & 1.6 \\
\hline Brașov & 7.7 & 70.7 & 24.3 & 2.7 & 2.3 \\
\hline Bratislava & 8.0 & 70.7 & 27.1 & 4.1 & 2.7 \\
\hline Budapest & 7.0 & 91.8 & 29.0 & 2.9 & 2.2 \\
\hline Burgas & 13.8 & 95.5 & 35.7 & 3.3 & 2.9 \\
\hline $\begin{array}{l}\text { Bursa } \\
\text { Nilüfer }\end{array}$ & 8.3 & 72.3 & 36.9 & 3.3 & 1.5 \\
\hline Celje & 10.1 & 97.6 & 29.5 & 5.8 & 2.4 \\
\hline Izola & 10.1 & 97.6 & 19.9 & 5.8 & 2.4 \\
\hline Klagenfurt & 9.2 & 75.9 & 23.0 & 6.1 & 3.1 \\
\hline Kranj & 10.1 & 97.6 & 24.6 & 5.8 & 2.4 \\
\hline Nitra & 8.0 & 70.7 & 26.4 & 4.1 & 2.7 \\
\hline Osijek & 9.7 & 90.4 & 33.2 & 3.9 & 2.8 \\
\hline Pécs & 7.0 & 91.8 & 30.5 & 2.9 & 2.2 \\
\hline Rome & 14.0 & 95.7 & 27.9 & 4.6 & 1.1 \\
\hline Turin & 14.0 & 95.7 & 39.0 & 4.6 & 1.1 \\
\hline Varna & 13.8 & 95.5 & 51.0 & 3.3 & 2.9 \\
\hline Velenje & 10.1 & 97.6 & 21.0 & 5.8 & 2.4 \\
\hline Zenica & 10.5 & 90.9 & 69.8 & 3.1 & 1.6 \\
\hline Average & 10.1 & 88.3 & 31.7 & 4.2 & 2.2 \\
\hline
\end{tabular}

\section{Carbon dioxide emissions and industrial profile $\left(D_{5}\right)$}

Based on Table 7, the average $\mathrm{CO}_{2}$ emissions of buildings in the cities are $1,122,711$ tonnes while it is 460,070 tonnes for transport. The average $\mathrm{CO}_{2}$ intensity is 0.27 tonnes per MWh. The lowest value is 0.15 tonnes of $\mathrm{CO}_{2}$ (Burgas) and the highest value is 0.36 tonnes of $\mathrm{CO}_{2}$ emissions (Braşov) per MWh. Surveys of energy intense industries are conducted based on sectoral reports, including those for important clusters of the chemical industry in Europe [151]. Overall, Bratislava, Burgas and Zenica have the greatest presence of energy intense industries, including iron and steel and petroleum products. Based on Table A4, an average city receives a score of 1.6 industries. Six airports that service the cities in the sample received Airport Carbon Accreditation (ACA) for reducing $\mathrm{CO}_{2}$ emissions per passenger based on energy savings on the supply and demand sides. Overall, accredited airports reduced $\mathrm{CO}_{2}$ emissions per passenger by about $14.8 \%$ in the years 2015 and 2016 [152-153], which exemplifies absolute decoupling [154] based on a 6.5\% decline in total airport $\mathrm{CO}_{2}$ emissions for Scope 1 and $2 \mathrm{CO}_{2}$ emissions despite an $8.9 \%$ growth in passenger traffic. Ljubljana Airport that services at least two cities in the sample (Celje and Kranj) is accredited for reducing airport $\mathrm{CO}_{2}$ emissions [124]. Leonardo da Vinci-Fiumicino Airport that services Rome has a CHP unit that covers $90 \%$ of the reduced electricity and heating demands and partially cooling loads. In addition, a smart grid project that involves photovoltaic and micro-mini wind turbines is completed [155]. Electrical energy per passenger reduced to $3.8 \mathrm{kWh}$ from $4.8 \mathrm{kWh}$ between 2010 and 2015 for a 22\% reduction [156]. 
Table 7. Data inputs to the $\mathrm{CO}_{2}$ emissions and industrial profile dimension $\left(D_{5}\right)$

\begin{tabular}{|c|c|c|c|c|c|}
\hline City $\left(C_{j}\right)$ & $\begin{array}{c}\mathrm{CO}_{2} \text { emissions of } \\
\text { buildings } \\
{\left[\mathrm{t} \mathrm{CO}_{2}\right]^{\mathrm{a}}}\end{array}$ & $\begin{array}{c}\mathrm{CO}_{2} \text { emissions } \\
\text { of transport } \\
{\left[\mathrm{t} \mathrm{CO}_{2}\right]^{\mathrm{a}}}\end{array}$ & $\begin{array}{c}\text { Average } \\
\mathrm{CO}_{2} \text { intensity } \\
{\left[\mathrm{t} \mathrm{CO}_{2} / \mathrm{MWh}\right]}\end{array}$ & $\begin{array}{l}\text { Number of } \\
\mathrm{CO}_{2} \text { intense } \\
\text { industries }^{\mathrm{b}}\end{array}$ & $\begin{array}{c}\text { Airport } \\
\text { ACA level }\end{array}$ \\
\hline Bijeljina & 362,791 & 85,428 & 0.26 & 1 & 0 \\
\hline Brașov & 761,994 & 153,459 & 0.36 & 4 & 0 \\
\hline Bratislava & $1,593,575$ & 816,733 & 0.24 & 5 & 0 \\
\hline Budapest & $6,984,132$ & $1,693,915$ & 0.31 & 3 & 3 \\
\hline Burgas & 308,854 & 55,126 & 0.15 & 4 & 0 \\
\hline Bursa Nilüfer & 404,236 & 285,127 & 0.25 & 3 & 0 \\
\hline Celje & 114,970 & 96,303 & 0.31 & 2 & 2 \\
\hline Izola & 30,597 & 15,422 & 0.24 & 0 & 0 \\
\hline Klagenfurt & 395,872 & 183,528 & 0.30 & 1 & 0 \\
\hline Kranj & 309,713 & 59,413 & 0.30 & 0 & 2 \\
\hline Nitra & 132,652 & 90,286 & 0.23 & 2 & 0 \\
\hline Osijek & 352,147 & 66,226 & 0.25 & 1 & 0 \\
\hline Pécs & 462,960 & 99,760 & 0.28 & 1 & 0 \\
\hline Rome & $4,491,482$ & $3,688,549$ & 0.22 & 1 & $3^{c}$ \\
\hline Turin & $2,737,000$ & 713,000 & 0.26 & 4 & 0 \\
\hline Varna & 408,460 & 137,856 & 0.24 & 2 & 0 \\
\hline Velenje & 147,488 & 13,081 & 0.35 & 1 & 2 \\
\hline Zenica & 209,874 & 28,048 & 0.32 & 5 & 0 \\
\hline Average & $1,122,711$ & 460,070 & 0.27 & 2.22 & 0.67 \\
\hline
\end{tabular}

\section{City planning and social welfare $\left(D_{6}\right)$}

Table 8 provides the data inputs into $D_{6}$. For example, the average price of a one-way public transport ticket is EUR 1.0. Four cities provide further data on the modal share of journeys to work. Bratislava has the highest share of journeys to work with public transport (87\%) while the average is $46 \%$ among reporting cities [157]. The average score for compact urban form and protected sites is 1.9. In total, over 200 green areas were surveyed to score urban park intensity and protected green corridors based on the World Database on Protected Areas [158]. In contrast, a higher mean percentage of impermeable surfaces in urban areas can increase the impact of heat waves and the risks of flooding due to extreme weather events. For example, the share of sealed surfaces was $36.6 \%$ in Klagenfurt and $62.9 \%$ in Budapest and Turin [159]. Table A5 also provides the number of reserves with special protection status and an area greater than $15 \mathrm{~km}^{2}$, the protected wetlands, and national parks within a $100 \mathrm{~km}$ radius of the city center.

In other aspects of $D_{6}$, seven cities have predominately monocentric urban forms while twelve cities are characterized to have polycentric urban forms. For example, Burgas and Varna have continuous urban fabric in centralized locations in the city [160]. $D_{6}$ further includes an assessment of cities under the Urban Waste Water Treatment Directive [161] for compliance with Biochemical (BOD) and Chemical Oxygen Demand (COD) as well as Total Suspended Solids (TSS). In the aspect of waste and waste management, the average amount of municipal solid waste per capita in the sample is $406 \mathrm{~kg}$. As a best practice, Celje uses municipal waste, sludge, and landfill gas in CHP units in waste to energy schemes (see Table A1 and A5). In addition, recycling rates in Slovenia are one of the highest rates in Europe at 55\% [162]. In contrast, the solid waste of Nitra is landfilled $50 \mathrm{~km}$ away from the city while only $10 \%$ of the waste is recycled [163]. Such aspects are differentiated under the scorings for municipal management.

In aspects of social welfare, the average GDP per capita is 25,852 international dollars adjusted for purchasing power parity. The lowest values are in Bijeljina and 
Zenica and the highest value is in Klagenfurt. As an assessment of social welfare beyond GDP per capita, inequality adjusted well-being scores have a low of 6.0 (Bursa Nilüfer) and a high of 7.7 (Klagenfurt) out of a possible score of 10. The well-being scores represent satisfaction with daily experience based on the views of the population that may be thriving, struggling or suffering [126]. The average tertiary education rate that also supports social welfare is $27.3 \%$. In addition to the pervasiveness of tertiary education, Pécs and Turin from the present city sample have been recognized as a "learning city" based on commitments to improve quality, excellence, and inclusiveness in education as a pillar of sustainable development $[164,165]$.

Table 8 . Data inputs to the city planning and social welfare dimension $\left(D_{6}\right)$

\begin{tabular}{|c|c|c|c|c|c|}
\hline City $\left(C_{j}\right)$ & $\begin{array}{c}\text { Accessibility of } \\
\text { public transport } \\
{[\text { EUR }]^{\mathrm{a}}}\end{array}$ & $\begin{array}{l}\text { Urban form } \\
\text { and municipal } \\
\text { management }^{\mathrm{b}}\end{array}$ & $\begin{array}{c}\text { GDP per } \\
\text { capita } \\
\text { [PPP\$ } \\
\text { national] }\end{array}$ & $\begin{array}{c}\text { Inequality } \\
\text { adjusted } \\
\text { well-being } \\
{[/ 10]}\end{array}$ & $\begin{array}{l}\text { National tertiary } \\
\text { education rate [\%] }\end{array}$ \\
\hline Bijeljina & 0.87 & 1.0 & $10,427.0$ & 6.2 & 18.0 \\
\hline Brașov & 0.44 & 2.0 & $21,635.0$ & 6.6 & 21.8 \\
\hline Bratislava & 0.90 & 2.3 & $28,327.0$ & 6.5 & 23.7 \\
\hline Budapest & 1.13 & 2.0 & $25,069.0$ & 6.9 & 29.9 \\
\hline Burgas & 0.51 & 2.0 & $17,208.0$ & 6.5 & 26.9 \\
\hline Bursa Nilüfer & 0.76 & 2.0 & $19,788.0$ & 6.0 & 22.0 \\
\hline Celje & 1.30 & 2.2 & $30,403.0$ & 6.8 & 39.2 \\
\hline Izola & 1.30 & 2.3 & $30,403.0$ & 6.8 & 39.2 \\
\hline Klagenfurt & 2.10 & 2.0 & $47,682.0$ & 7.7 & 26.3 \\
\hline Kranj & 1.00 & 1.7 & $30,403.0$ & 6.8 & 39.2 \\
\hline Nitra & 0.72 & 2.0 & $28,327.0$ & 6.5 & 23.7 \\
\hline Osijek & 1.46 & 1.7 & $21,635.0$ & 6.2 & 23.7 \\
\hline Pécs & 1.16 & 1.7 & $25,069.0$ & 6.9 & 29.9 \\
\hline Rome & 1.50 & 2.7 & $35,463.0$ & 7.1 & 21.7 \\
\hline Turin & 1.50 & 2.0 & $35,463.0$ & 7.1 & 21.7 \\
\hline Varna & 0.51 & 2.0 & $17,208.0$ & 6.5 & 26.9 \\
\hline Velenje & 0.00 & 1.7 & $30,403.0$ & 6.8 & 39.2 \\
\hline Zenica & 0.51 & 1.0 & $10,427.0$ & 6.2 & 18.0 \\
\hline Average & 1.0 & 1.9 & $25,852.2$ & 6.7 & 27.3 \\
\hline
\end{tabular}

\section{Research and development, innovation and sustainability policy $\left(D_{7}\right)$}

For $D_{7}$, Table 9 provides the main data inputs and Tables A6-A8 provide those of the sub-indicators. The average score for Research and Development (R\&D) and innovation policy orientation is 2.0 based on $R \& D$ spending and priorities in funding. Based on the national level, 3 cities have thematic calls and priorities in the areas of energy and environment, namely Klagenfurt, Osijek, and Bursa Nilüfer. Klagenfurt has the highest number of patents $(20,145)$ with green patent codes while Osijek has the highest share of green patents $(2.82 \%)$ in total patents. Both aspects are used to determine the final score based on Table A7. As local knowledge institutions, Budapest has the highest number of universities in the local innovation system and the most academic institutions in the Scimago rankings. For cities with available data in Urban Audit, the number of tertiary students (ISCED 5 and 6) range between 9,725 (Burgas) and 154,235 students (Budapest) [157]. The knowledge production capacity based on the average $h$-index is 281. The average $\mathrm{CO}_{2}$ emissions target is a $25 \%$ reduction with the highest target set at $40 \%$ (Klagenfurt). Such targets are essential to allow cities in spearheading local climate action towards attaining climate neutrality by mid-century in support of Articles 2 and 4 of the Paris Agreement [2, 166]. 
Table 9. Data inputs to the $R \& D$, innovation and sustainability policy dimension $\left(D_{7}\right)$

\begin{tabular}{|c|c|c|c|c|c|}
\hline City $\left(C_{j}\right)$ & $\begin{array}{c}\text { R\&D and innovation } \\
\text { policy orientation }^{\mathrm{a}}\end{array}$ & $\begin{array}{l}\text { National patents in } \\
\text { clean technologies }\end{array}$ & $\begin{array}{l}\text { Universities in the } \\
\text { local ecosystem }{ }^{\mathrm{c}}\end{array}$ & $\begin{array}{l}\text { National } \\
h \text {-index } \\
\end{array}$ & $\begin{array}{c}\text { Reduction target for } \\
\mathrm{CO}_{2} \text { emissions }\end{array}$ \\
\hline Bijeljina & 1.0 & 1.5 & 2 & 61 & 31 \\
\hline Brașov & 1.5 & 1.0 & 4 & 187 & 32 \\
\hline Bratislava & 1.5 & 1.0 & 11 & 195 & 20 \\
\hline Budapest & 1.5 & 1.5 & 24 & 329 & 21 \\
\hline Burgas & 2.0 & 1.0 & 2 & 184 & 25 \\
\hline Bursa Nilüfer & 2.5 & 1.0 & 4 & 296 & 20 \\
\hline Celje & 2.5 & 1.0 & 3 & 204 & 21 \\
\hline Izola & 2.5 & 1.0 & 2 & 204 & 20 \\
\hline Klagenfurt & 3.0 & 2.0 & 3 & 487 & 40 \\
\hline Kranj & 2.5 & 1.0 & 1 & 204 & 21 \\
\hline Nitra & 1.5 & 1.0 & 4 & 195 & 21 \\
\hline Osijek & 2.5 & 1.5 & 2 & 194 & 22 \\
\hline Pécs & 1.5 & 1.5 & 2 & 329 & 34 \\
\hline Rome & 2.0 & 2.0 & 13 & 766 & 20 \\
\hline Turin & 2.0 & 2.0 & 5 & 766 & 30 \\
\hline Varna & 2.0 & 1.0 & 5 & 184 & 25 \\
\hline Velenje & 2.5 & 1.0 & 1 & 204 & 23 \\
\hline Zenica & 1.0 & 1.5 & 1 & 61 & 20 \\
\hline Average & 2.0 & 1.3 & 5 & 281 & 25 \\
\hline
\end{tabular}

\section{RESULTS AND DISCUSSION}

The data inputs for the new sample of 18 SEE cities as given in Tables 3-9 are normalized according to the direction of the indicators in Table 2 and aggregated into the SDEWES Index based on eq. (1). In this process, the range of the indicators for the 18 new cities is compared with those for the previous city samples of Mediterranean port cities [3], SEE cities [5], and world cities [6]. In 34 of the 35 indicators in the index, the range of the previous city samples had a defining role in the minimum and maximum values. In these cases, the minimum and maximum values of the present sample were within the previous range. In the indicator for $\mathrm{PM}_{10}$, one city in the present sample was an outlier and received the value of zero according to the winsorization method [167]. In this method, outliers are assigned either a value of 1 or 0 as the highest or lowest possible values according to the direction of the specific indicator. Thus, the normalized values of the new sample are compatible with those of the previous samples.

The normalized values of the indicators per dimension are provided in Figures 2-8 that are also used within the SDEWES Index Benchmarking Tool (see Figure 10 in subsequent sections for a screenshot). The SDEWES Index Benchmarking Tool has functionalities for comparing the overall performance of cities and dimension performance. The Benchmarking Tool for the present sample of $18 \mathrm{SEE}$ cities is provided as a downloadable Appendix B of this manuscript.

\section{Results for energy consumption and climate}

The stacked bar chart of Figure 2 provides the normalized values of the indicators in $D_{1}$ for the $18 \mathrm{SEE}$ cities in the sample. The labels indicate the total unweighted score for $D_{1}$ prior to the aggregation in eq. (1). Accordingly, Varna (3.81), Zenica (3.73), Braşov (2.69) and Bursa Nilüfer (3.65) are the top performing cities in $D_{1}$ based on normalized values that are in the top $25 \%$ of values $\left(Q_{4}\right)$. This performance is followed by those of Burgas and Bijeljina. The sample average $C_{A V}$ is 3.37, which is given as the last stacked bar in Figure 2 and extended with a dotted line as a reference value. The ratios of the total $D_{1}$ values for each city $C_{j}$ over $C_{A V}$ is given in the triangular markings that range between 1.13 and 0.70 . Cities that minimize energy usage in buildings and transport relative to both population and climate have a better performance in $D_{1}$. 


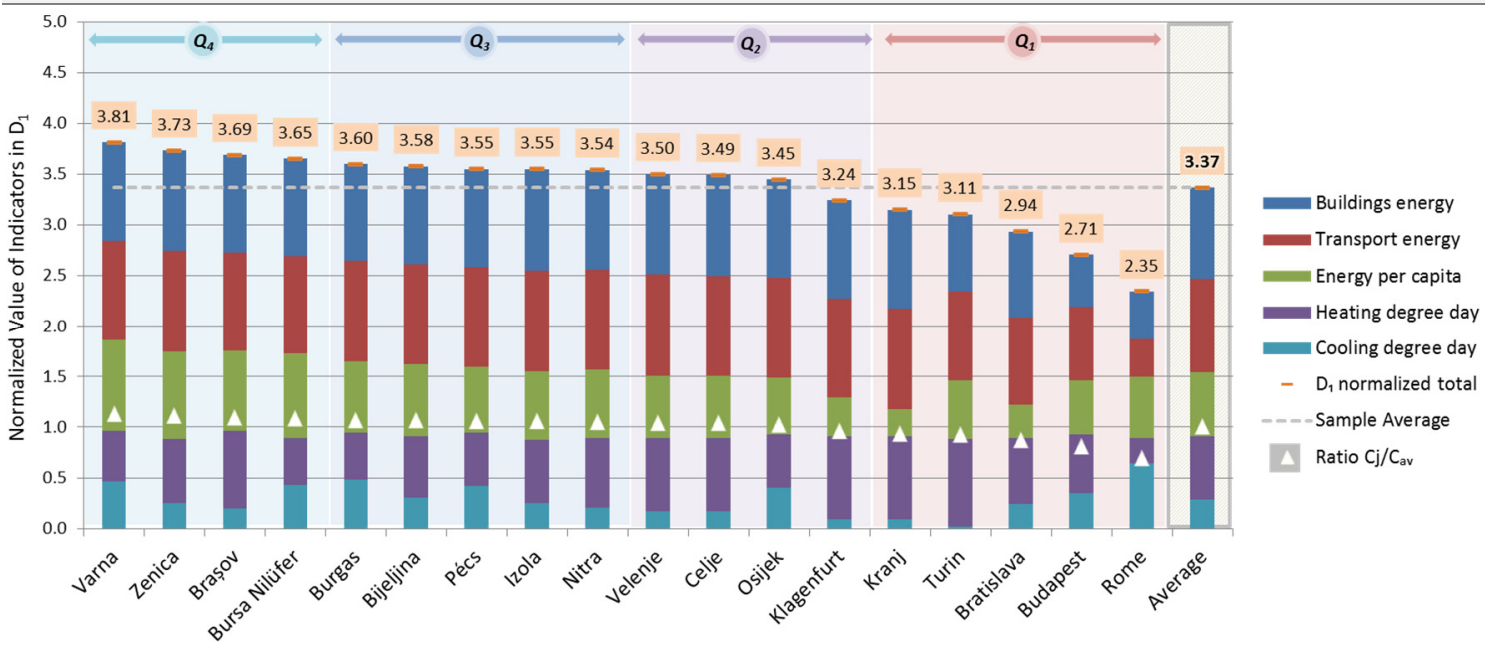

Figure 2. Normalized values of the indicators in $D_{1}$

\section{Results for penetration of energy and carbon dioxide saving measures}

Figure 3 presents the normalized values of the indicators in $D_{2}$ for the $18 \mathrm{SEE}$ cities in the sample. Based on multiple aspects of energy and $\mathrm{CO}_{2}$ saving measures, Budapest (4.57), Turin (4.08) and Bratislava (3.72) receive the highest scores in this dimension. Osijek and Pécs (3.54) closely follow the performance of these cities and also take place among the cities in $Q_{4}$. In comparison to others, these cities put forth best practises in adopting an integrated approach to optimize the energy system from both the supply and demand sides. These best practices include diffusing CHP based DH/C networks, implementing pilot nZEB projects, and/or connecting multiple modes of public transport towards a more energy efficient city. These include urban rail systems, including light rail trams that can provide a $6 \%$ reduction in the $\mathrm{CO}_{2}$ emissions from urban mobility alongside other benefits for traffic flow and air quality [168]. At the same time, such infrastructure may also need to be protected from climate vulnerabilities, including segments of the public transport network that may be located in floodplains [169].

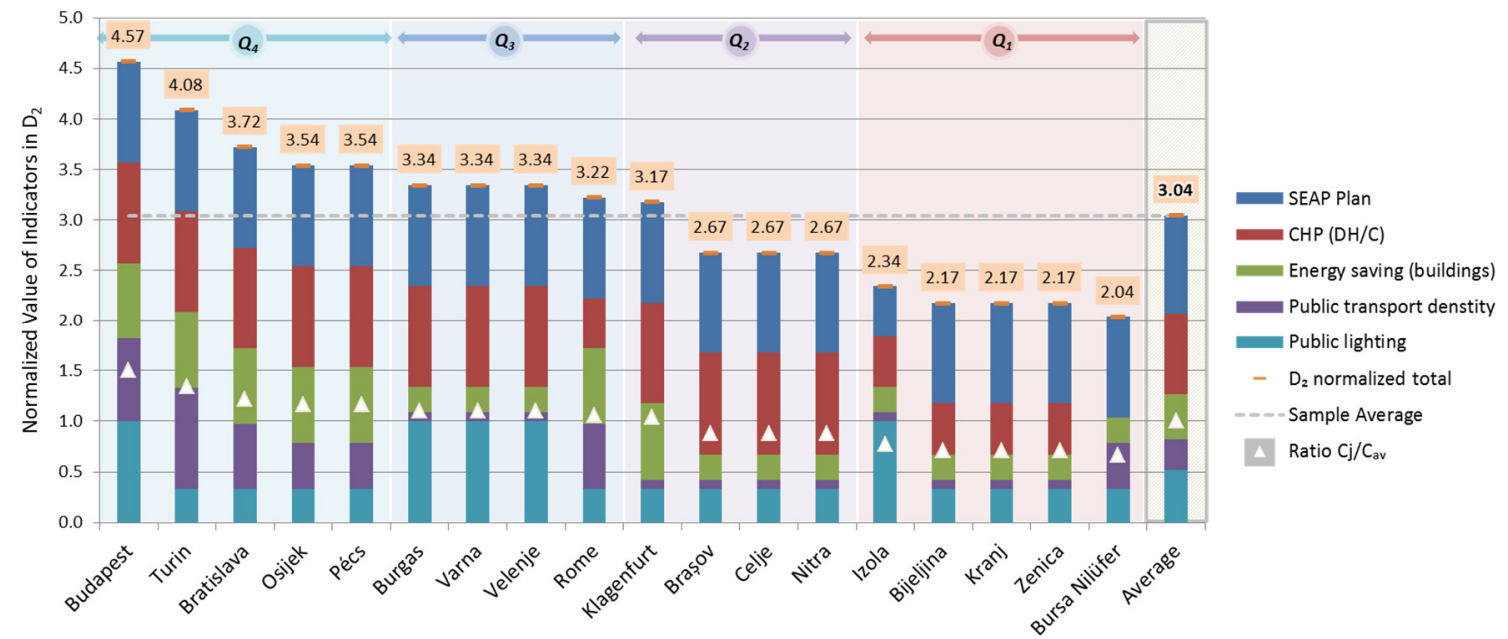

Figure 3. Normalized values of the indicators in $D_{2}$

Moreover, as indicated in Table A1, the energy system of Budapest is based on a CHP system with a power-to-heat ratio of 0.5 and about a 30\% savings in primary energy [170]. Turin has three combined-cycle CHP plants for $1,200 \mathrm{MW}_{\mathrm{e}}$ of electrical power and $740 \mathrm{MW}_{\mathrm{t}}$ of thermal power in cogeneration mode [171]. Other cities have best practices 
mostly on the supply side and include Varna that has a biomass boiler with an ORC that provides for 3.8 $\mathrm{MW}_{\mathrm{t}}$ of heat recovery [172]. In contrast, the opportunity to use excess heat is currently not utilized in these cities, including those from industry in Braşov [173] and Osijek [174]. Rome is planning to transition to a CHP based DH network that will have up to $50 \%$ input from biofuels [102].

In another aspect, the cities that receive top scores in Figure 3 also have nZEB related implementations. For example, as indicated in Table A2, Budapest has a residential complex that has an nZEB status [175] while Rome and Turin have sites for climate neutral urban districts [176]. Cities in which high exergy resources are mostly being used to meet the low exergy demands of space heating and cooling [177] are disadvantaged in $D_{2}$. Comparisons such as these are useful for policy learning across cities for saving both energy and exergy. For example, some cities, such as Bursa Nilüfer, rely on individual heating of buildings based on high exergy resources. The city can better utilize lower exergy energy resources in the future.

\section{Results for renewable energy potential and utilization}

In Figure 4, the normalized values of the indicators in $D_{3}$ for the 18 SEE cities in the sample indicate that Klagenfurt (2.59) has the highest performance across multiple indicators for renewable energy potential and its utilization, which is rewarded in $D_{3}$. Based on the indicators in Table 2, Klagenfurt may have a relatively lower renewable energy potential than some of the other cities but has the highest shares in renewable energy utilization. Rome (2.29), Osijek (2.27), Bursa Nilüfer (2.19), and Burgas (2.14) also perform in the top $25 \%$ of values for $D_{3}$.

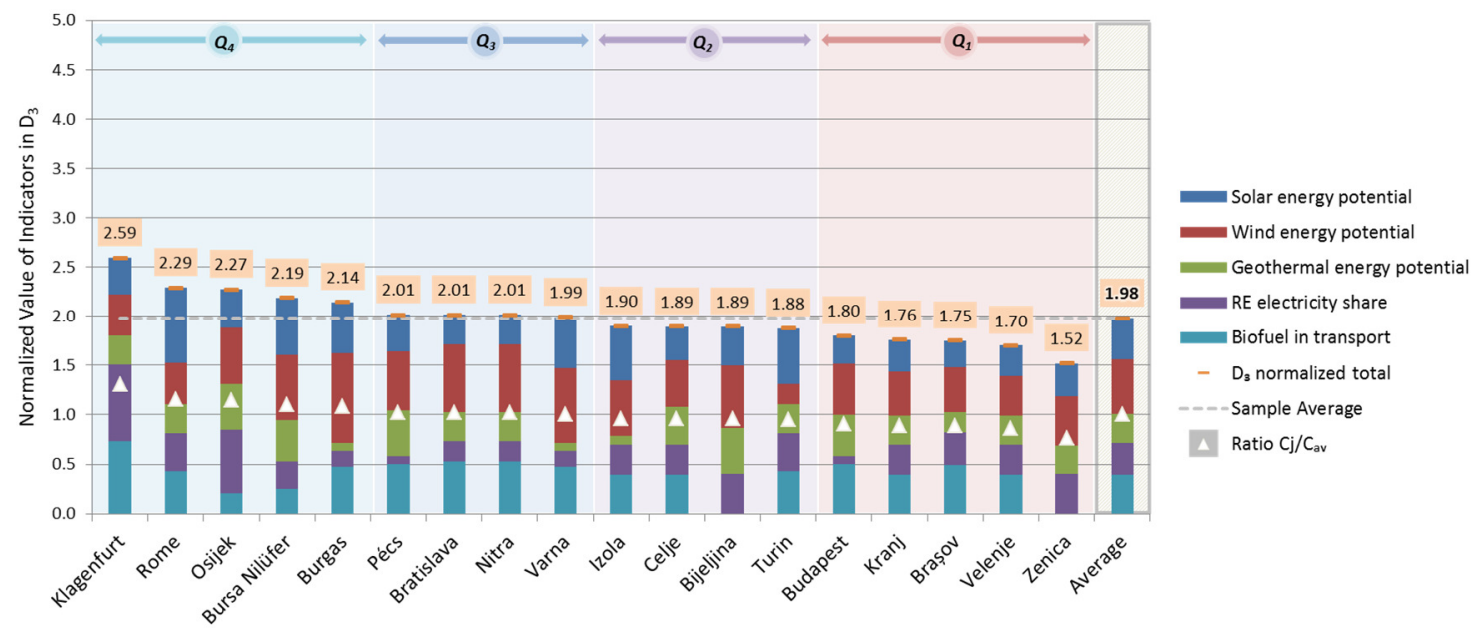

Figure 4. Normalized values of the indicators in $D_{3}$

As best practices, cities in $D_{3}$ integrate the local renewable energy potential into the power grid and thermal energy networks. These best practices may be initiated in pilot districts that may then be up-scaled to the larger city level. For example, the energy concept of Pécs is based on local straw and woodchips as locally available biomass to generate $35 \mathrm{MW}_{\mathrm{e}}$ and $70 \mathrm{MW}_{\mathrm{t}}$ of electrical and thermal power, respectively [178]. In addition, Nitra (2.01) in $Q_{3}$ uses geothermal energy to supply about $40 \%$ of the $24,167 \mathrm{MW}_{\mathrm{t}}$ of thermal power in the DH network [179].

Other cities may have a favourable performance in renewable energy potential but lack the utilization of these resources. Bijeljina (1.89) that has the highest geothermal energy potential in the sample is planning to integrate geothermal energy into the coal-based district heating system [147]. The use of this local renewable energy resource 
in the supply structure of the city may also improve its performance in multiple dimensions beyond $D_{3}$, including $D_{2}$ and $D_{5}$.

\section{Results for water and environmental quality}

Based on the normalized values in Figure 5, Budapest (3.38) and Pécs (3.35) have the highest performance in $D_{4}$ among the 18 SEE cities in the sample. Such a result indicates that both cities have a holistic approach to water and environmental quality and are able to obtain related advantages, including better air quality. Bijeljina, Braşov and Izola are other cities that perform in the top $25 \%$ of values in $D_{4}$. Other cities with lower performances in $D_{4}$, such as Celje (2.86), have relatively high water quality but obtain a less favourable outcome in the other indicators, such as ecological footprint per capita. In contrast, cities that take place in the lowest $25 \%$ of values in $D_{4}$ have certain shortcomings in more than one indicator. For example, Zenica (2.46) is given to have the worst air quality among the cities in the sample. Hence, the ability to reach top performance in $\mathrm{D}_{4}$ necessitates a consistent performance across multiple indicators, including water consumption, water quality, minimized air pollution, and ecological footprint.

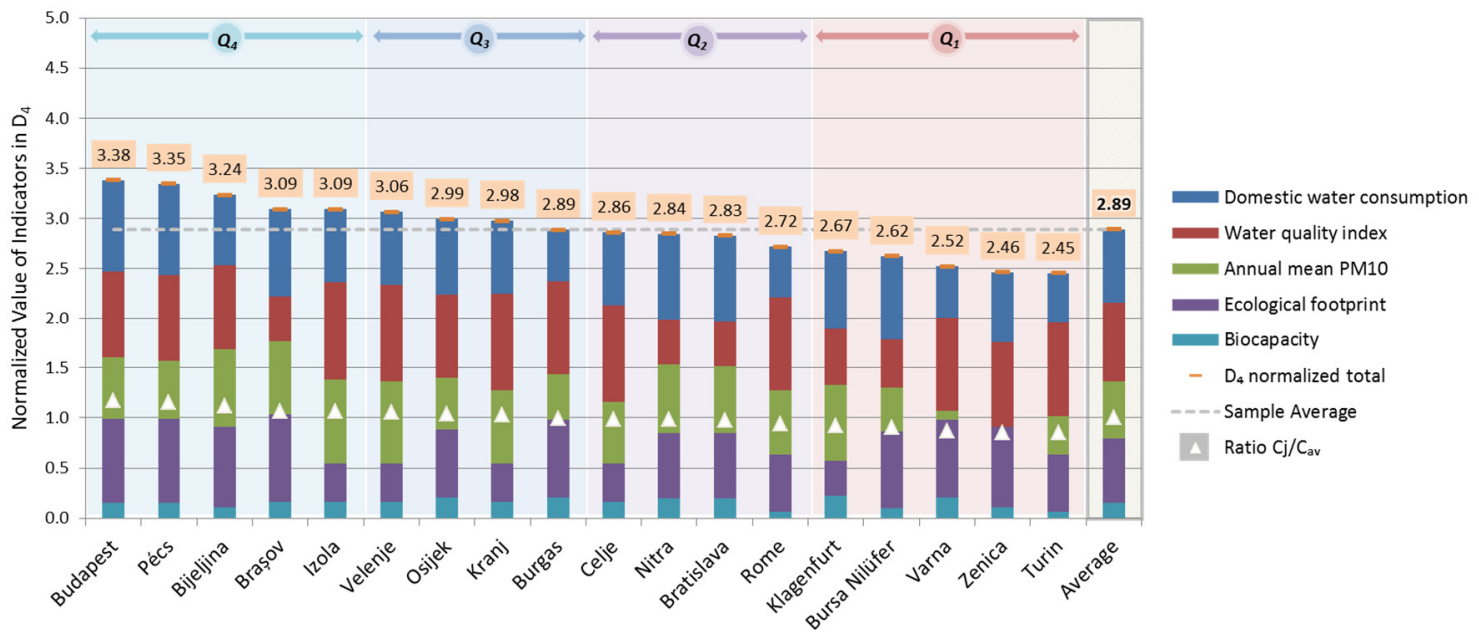

Figure 5. Normalized values of the indicators in $D_{4}$

\section{Results for carbon dioxide emissions and industrial profile}

Figure 6 provides the normalized values of the indicators in $D_{5}$ for the 18 SEE cities in the sample. Kranj (4.02) has the best performance in the related indicators for $\mathrm{CO}_{2}$ emissions and industrial profile. Velenje (3.78), Celje (3.75), and Izola (3.74) are the next best performing cities in $D_{5}$ with performances in $Q_{4}$. Among these cities, Izola has no direct energy intense industry although the Port of Koper is nearby. In contrast, the performances of Bratislava (2.87) and Zenica (2.85) that take place among cities that perform below the $D_{5}$ average are limited due to the presence of energy intense industries, which places a greater need for $\mathrm{CO}_{2}$ mitigation. Cities that excel in $D_{5}$ reduce $\mathrm{CO}_{2}$ emissions relative to energy usage, minimize the presence of energy intense industries and reduce the $\mathrm{CO}_{2}$ emissions impact of the airport servicing the city. Currently, $\mathrm{CO}_{2}$ reductions in the building sector are surpassed by those in public and private transport. For example, Nitra that takes place in the quartile of $Q_{3}$ achieved a $13.2 \%$ reduction in residential buildings when compared to its baseline while $75 \%$ of the measures for this sector are still ongoing [98]. An energy systems approach will further expedite improvements in $D_{5}$. 


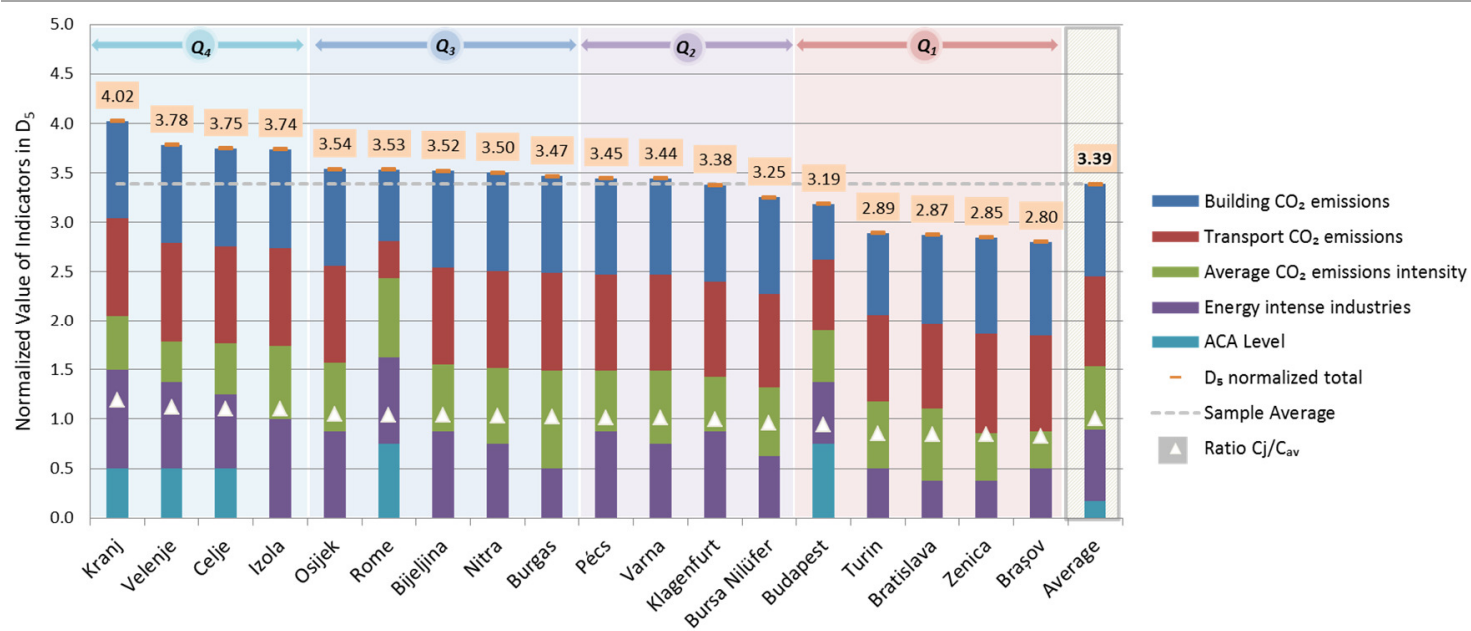

Figure 6. Normalized values of the indicators in $D_{5}$

\section{Results for city planning and social welfare}

In Figure 7, the normalized values of the indicators in $D_{6}$ indicate that Izola (3.09), Velenje (3.09) and Klagenfurt (3.08) are the best performing cities for city planning and social welfare. Celje (3.04) and Rome (2.97) are other cities with advantages in multiple indicators under $D_{6}$. Relative to the other cities in the present sample, a performance in the top $25 \%$ of values can be explained by the efforts of these cities for compact urban form while preserving urban green spaces and protecting surrounding areas. Favourable socio-economic indicators, including GDP per capita and/or the tertiary education rate are other factors that further enhance the performance of these cities in $D_{6}$. Best practices from the top performing cities in $D_{6}$ include those of Klagenfurt that has the most distinct profile of green corridors with 1 nature reserve, 2 Ramsar wetland sites, and 1 national park (see Table A7). Celje has a waste to energy scheme to increase the valorisation of municipal waste. In aspects of social welfare, Slovenian cities have the highest tertiary education rate. Cities can improve their level of performance in $D_{6}$ by increasing measures that address city planning, municipal management, and social welfare.

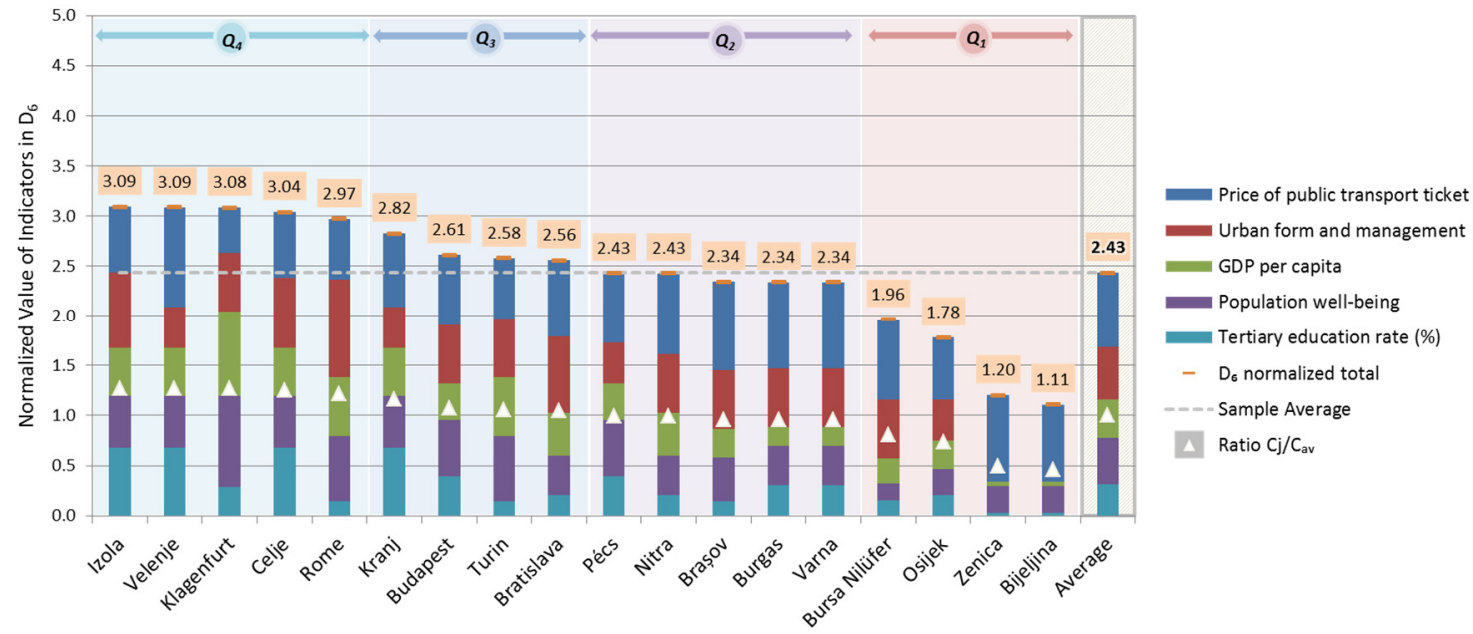

Figure 7. Normalized values of the indicators in $D_{6}$

\section{Results for research and development, innovation and sustainability policy}

Figure 8 puts forth the normalized values of the indicators in $D_{7}$. Here, Klagenfurt (2.91), Rome (2.46), Turin (2.42), Budapest (2.15) and Osijek (1.88) take place as the cities with the best performance in $\mathrm{R} \& \mathrm{D}$, innovation, and sustainability policy among the 
cities in the sample. These cities have assets in being able to combine a strong knowledge production and technology development capability with an ambitious $\mathrm{CO}_{2}$ emissions reduction target. Such an asset, including patents in clean technologies, is essential to support the contextual framework in which cities work to realize $\mathrm{CO}_{2}$ emission reduction targets. In contrast, cities in quartiles other than $Q_{4}$ have certain limitations and perform below the average value $\left(C_{A V}\right)$ of 1.76 in $D_{7}$. For example, Nitra (1.26), Bijeljina (1.25) and Zenica (0.97) do not possess the same advantages that may place a greater need for knowledge transfer to these cities. The best practices in $D_{7}$ emphasize that cities can build capacities to be hubs of sustainable innovation. City partnerships may also give impetus to more solution-oriented sustainability research [180].

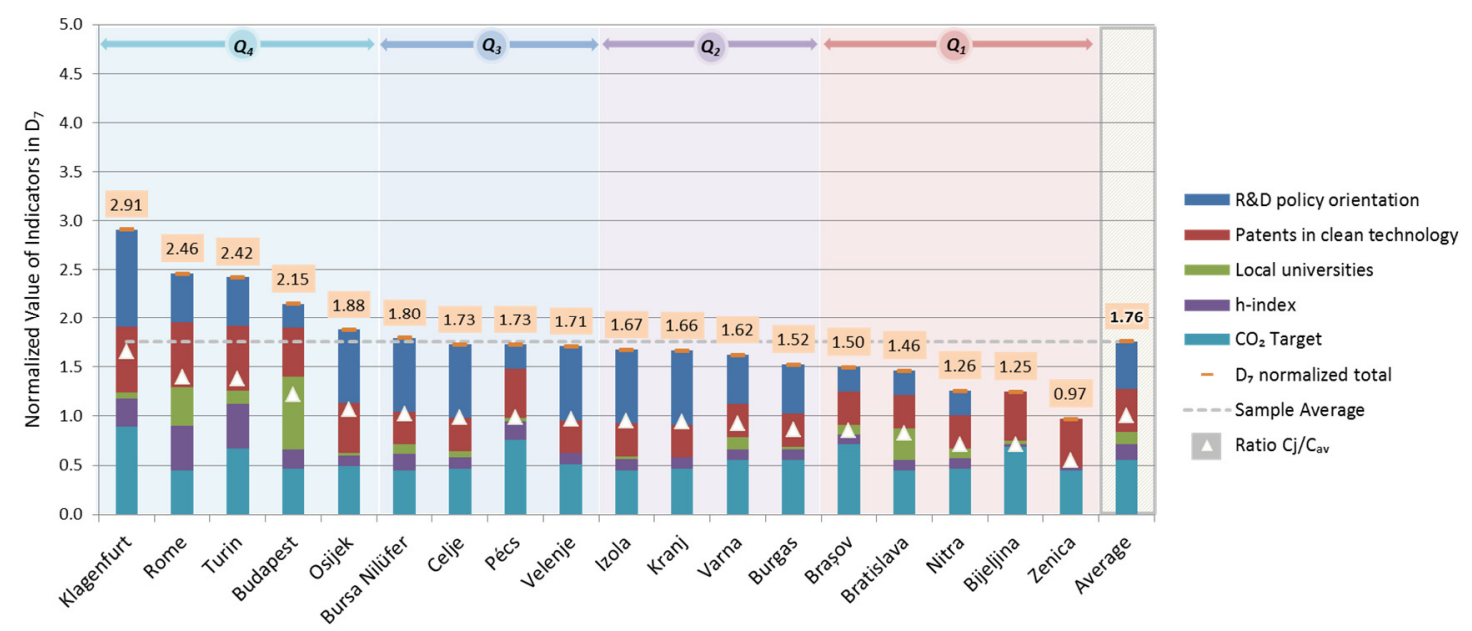

Figure 8. Normalized values of the indicators in $D_{7}$

\section{Results of the Sustainable Development of Energy, Water and Environment Systems Index for South East European cities}

Table 10 provides the results of the SDEWES Index when the normalized values are aggregated based on eq. (1). The top three cities in the present sample are Klagenfurt (SDEWES = 3.08), Velenje (3.06) and Pécs (3.01). As referred from Figures 2-8, these top cities consistently have the highest value in the most number of dimensions and/or exceed the average with a greater difference in multiple dimensions. The average city in the sample receives a score of SDEWES $\left(C_{j}\right)=2.85$. The results in Table 10 allow a comparative approach to benchmark cities and underline the need to adopt well-rounded policy efforts to increase the sustainable development of energy, water and environment systems in cities across multiple dimensions. Weaknesses in certain dimensions may also be used to identify areas of strategic intervention for improvement. The percentage difference with the sample average is further provided as a basis of comparison. For example, Klagenfurt has a performance at $8.1 \%$ above the sample average based on eq. (3). In contrast, the lowest performing city, namely Zenica, is found to perform about $15.8 \%$ below average when compared to the sample average.

Table 10. Ranking of the SEE sample based on the SDEWES Index

\begin{tabular}{cccccccc}
\hline City $\left(C_{j}\right)$ & Index & Rank & $\% \Delta C_{A V}$ & City $\left(C_{j}\right)$ & Index & Rank & $\% \Delta C_{A V}$ \\
\hline Klagenfurt & 3.08 & 1 & 8.09 & Kranj & 2.86 & 10 & 0.37 \\
Velenje & 3.06 & 2 & 7.39 & Turin & 2.83 & 11 & -0.68 \\
Pécs & 3.01 & 3 & 5.63 & Rome & 2.82 & 12 & -1.03 \\
Izola & 2.97 & 4 & 4.23 & Nitra & 2.81 & 13 & -1.38 \\
Celje & 2.96 & 5 & 3.88 & Bursa Nilüfer & 2.72 & 14 & -4.54 \\
Osijek & 2.94 & 6 & 3.18 & Brașov & 2.70 & 15 & -5.24 \\
Burgas & 2.94 & 7 & 3.18 & Bratislava & 2.69 & 16 & -5.60 \\
Varna & 2.93 & 8 & 2.83 & Bijeljina & 2.66 & 17 & -6.65 \\
Budapest & 2.91 & 9 & 2.13 & Zenica & 2.40 & 18 & -15.77 \\
& & & & Average & 2.85 & - & -0.00 \\
\hline
\end{tabular}




\section{Comparison of the results based on Monte Carlo experiments}

In addition to the results in Table 10, the normalized values of the indicators are subjugated to random weights based on 10,000 Monte Carlo experiments. Accordingly, indicator weights are generated randomly and applied within the context of eq. (1) for all cities in the sample.

Figure 9 provides the box plot of the experiments in which the cities in the sample are ordered based on mean simulated values. The original rankings in Table 10 is upheld in the rankings in Figure 9, which indicates that the mean simulated values of the Monte Carlo experiments for cities $C_{j}$ are in conformity with the ranking of the results of the SDEWES Index based on eq. (1). The mean simulated values are also used to sub-divide the index results into quartiles so that cities performing above or below the median $(\tilde{x})$ value of SDEWES $=2.89$ are characterized to be in the top or bottom $50 \%$ of observations. In particular, cities with index values above $2.96\left(Q_{4}\right), 2.89\left(Q_{3}\right)$ or 2.74 $\left(Q_{2}\right)$ or equal to or less than $2.74\left(Q_{1}\right)$ are included in the associated quartiles in Figure 9. These quartiles are attributed to contain the pioneering $\left(Q_{4}\right)$, transitioning $\left(Q_{3}\right)$, solution-seeking $\left(Q_{2}\right)$ and challenged cities $\left(Q_{1}\right)$ of the present sample.

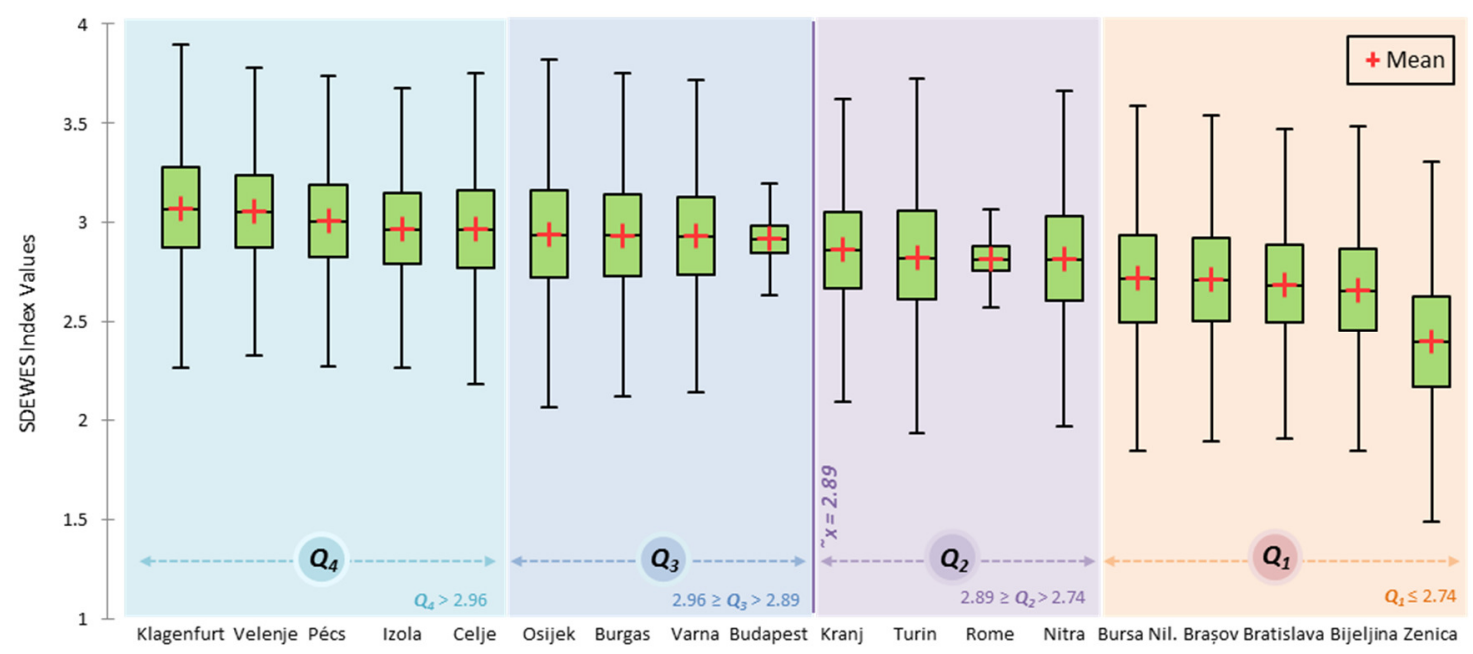

Figure 9. Results of the 10,000 Monte Carlo experiments

The pioneering cities of the sample. Based on Figure 9, five cities are identified to take place in the top $25 \%$ within $Q_{4}$ as the pioneering cities of the sample. These cities, namely, Klagenfurt, Velenje, Pécs, Izola and Celje, can each provide best practices in more than one dimension. For example, Klagenfurt has one of the highest renewable energy shares in the electricity mix in $D_{3}$.

The transitioning cities of the sample. The next four cities, namely Osijek, Burgas, Varna and Budapest, are cities that have certain strengths in specific dimensions. For example, Budapest has commendable levels of performance in $D_{2}$ and $D_{4}$. In some of the other dimensions, the city may require a transition to attain higher levels of performance, including in $D_{3}$. While cities in $Q_{3}$ have an above median performance, there are still opportunities to improve to reach $Q_{4}$.

The solution-seeking cities of the sample. The cities in $Q_{2}$ are identified to be those that need to seek more urban solutions to balance levels of performance across the SDEWES Index. In the present sample, these cities are Kranj, Turin, Rome and Nitra. For example, Turin and Rome both have advantages in $D_{7}$ while their performance in the other dimensions is more varied. The measures that these cities are implementing can be diversified, including aspects of air quality. 
The challenged cities of the sample. The five cities in $Q_{1}$, namely Bursa Nilüfer, Braşov, Bratislava, Bijeljina and Zenica have multiple challenges that require policy attention, including issues of energy and development. With the exception of Bratislava, these cities also need to strengthen energy and $\mathrm{CO}_{2}$ mitigation measures relative to the other cities in the sample. An example for Bursa Nilüfer is provided based on the SDEWES Index Benchmarking Tool.

\section{Sustainable Development of Energy, Water and Environment Systems Index Benchmarking Tool}

Figure 10 applies the SDEWES Index Benchmarking Tool that is first developed in [6] to the results of the present sample. This tool may be used to compare two cities based on the overall performance across all dimensions (top section) and/or to the sample for a particular dimension (bottom section). In Figure 10, Bursa Nilüfer (ranked 14 in the SDEWES Index) is compared with Budapest (ranked 9). The two cities that are five rankings apart have different patterns in nearing or exceeding the sample average. In addition, dimension $D_{2}$ is selected to benchmark the cities with the SEE sample to indicate domains in which policy gaps may exist. For example, Bursa Nilüfer that is ranked 18 in $D_{2}$ uses mostly natural gas, which is a high exergy resource, for space heating and cooling in buildings. In contrast, the city may utilize the geothermal energy potential that is currently used sparingly in the tourism sector [92] to heat local residential buildings in an eco-district concept in the future. The city is currently designated as a replicator city under the Smart Cities Light House projects that focus on energy and transport measures $[92,181]$. In the other dimensions, Bursa Nilüfer can be paired with cities that may have similar or different performances according to policy learning objectives.

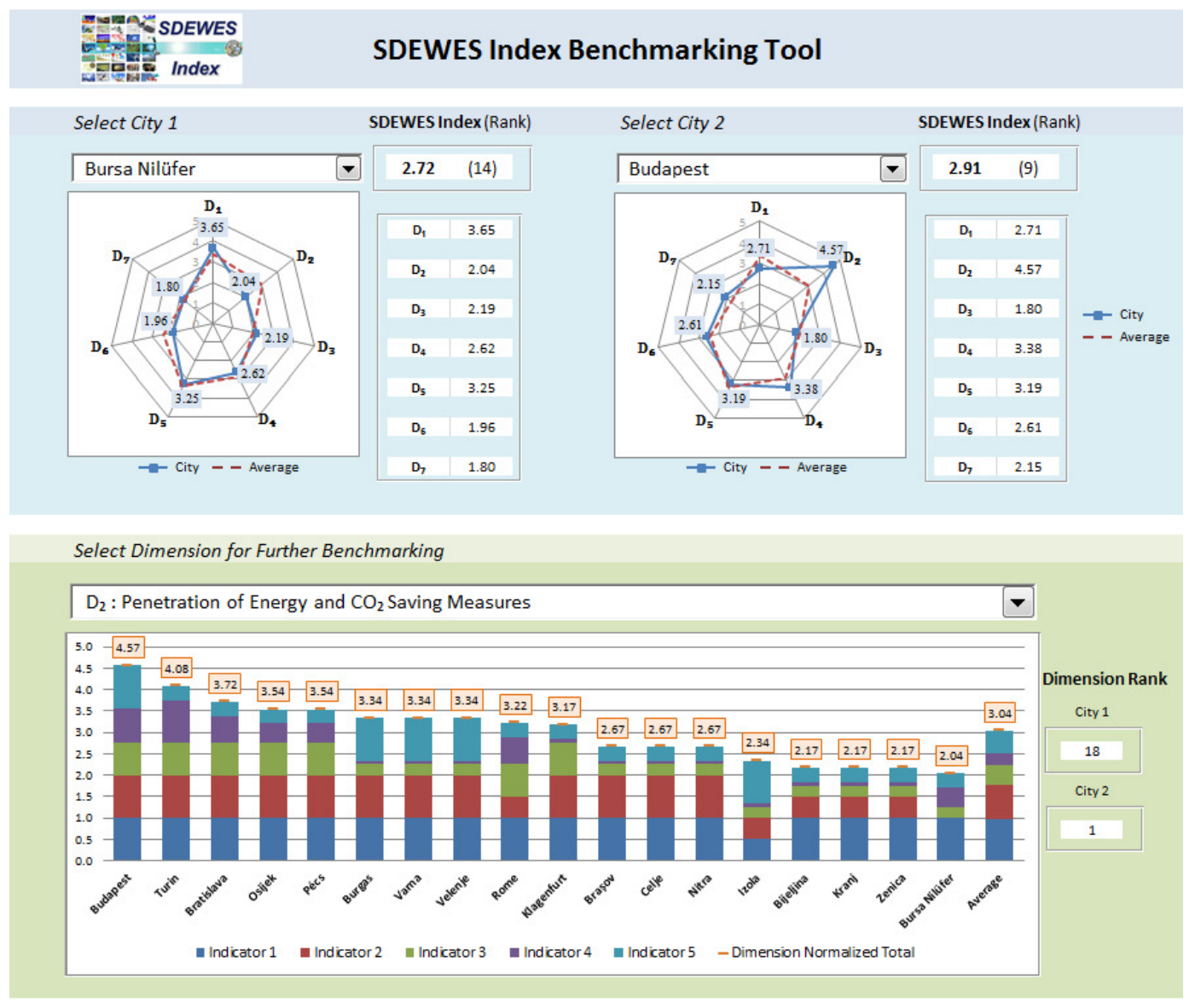

Figure 10. SDEWES Index Benchmarking Tool for Policy Learning 
Interactions with the radar and bar charts can be used to compare the potential for strategic interventions towards more innovative urban systems. For example, Klagenfurt that is ranked first has the highest $\mathrm{CO}_{2}$ reduction target for the year 2030 at a $40 \%$ reduction from the base year [95]. The city can better reach its target by mobilizing its $\mathrm{R} \& \mathrm{D}$ and innovation competence so that the waste of one system becomes the input of another. In another aspect, Izola (ranked 4) plans to deploy sea-water based cooling [94]. A partnership model that involves cooperating institutions and the transfer of knowledge from local examples, such as a resort in Piran that used the technology [182], can enable Izola to improve its ranking in the SDEWES Index. The ability to improve multiple indicators of the SDEWES Index at the same time will be possible with well-designed solutions. In addition, any use of bioenergy sources that meets sustainability criteria must be below emission limit values [183] that will increase benefits for public health.

\section{Identification of city pairs for policy learning}

Based on eq. (4), Table 11 exemplifies the use of the search algorithm to find cities with similar dimension performances. Cities from the previous two samples are added to diversify the overall possibilities. Among a total of 76 cities to which the index is applied to date, 8 common patterns that involve 8 cities from the present sample and 17 cities from the previous samples are found. Table 11 marks the common patterns for the city pairs based on values that are at or above $(\uparrow)$ or below $(\downarrow)$ the overall sample averages in the 7 dimensions of the SDEWES Index. In various combinations, the first 4 city pairs have above average performance in at least 4 dimensions. The last 4 city pairs have below average performance in at least 4 dimensions.

Table 11 can be used to mobilize policy learning opportunities in a targeted way to improve the performance of the cities. For example, the city pair of $P_{1}$ that contains Budapest from the present sample has an above average performance in $D_{2}, D_{4}, D_{5}, D_{6}$ and $D_{7}$. In contrast, the city pair of $P_{5}$ in which Bursa Nilüfer from the present sample takes part has below average performances in the same dimensions except for $D_{5}$. The decision makers in these cities can observe that exchanges across the cities in complementary aspects may provide opportunities to find best practices. In addition, Zenica (present sample), Cluj-Napoca and Skopje (previous samples) perform below average in all dimensions except $D_{1}$. Based on common areas of need, this city pair $P_{8}$ can address such issues and seek best practices from cities that have a higher performance in these dimensions.

Table 11. Identification of cities with common patterns

\begin{tabular}{|c|c|c|c|c|c|c|c|c|c|}
\hline \multirow{2}{*}{$P_{R}$} & \multirow{2}{*}{ City in new sample } & \multirow{2}{*}{ City in previous samples $[3,5-7]$} & \multicolumn{7}{|c|}{ Pattern } \\
\hline & & & $D_{1}$ & $D_{2}$ & $D_{3}$ & $D_{4}$ & $D_{5}$ & $D_{6}$ & $D_{7}$ \\
\hline$P_{1}$ & Budapest & Zagreb, Espoo & $\downarrow$ & $\uparrow$ & $\downarrow$ & $\uparrow$ & $\uparrow$ & $\uparrow$ & $\uparrow$ \\
\hline$P_{2}$ & Rome & Naples & $\downarrow$ & $\uparrow$ & $\uparrow$ & $\downarrow$ & $\uparrow$ & $\uparrow$ & $\uparrow$ \\
\hline$P_{3}$ & Izola & Ohrid, Zadar & $\uparrow$ & $\downarrow$ & $\downarrow$ & $\uparrow$ & $\uparrow$ & $\uparrow$ & $\downarrow$ \\
\hline$P_{4}$ & Braşov & Podgorica, Niš, Timişoara, Rijeka & $\uparrow$ & $\downarrow$ & $\downarrow$ & $\uparrow$ & $\downarrow$ & $\downarrow$ & $\downarrow$ \\
\hline$P_{5}$ & Bursa Nilüfer & Kalamariá, Seferihisar, Bornova & $\uparrow$ & $\downarrow$ & $\uparrow$ & $\downarrow$ & $\uparrow$ & $\downarrow$ & $\downarrow$ \\
\hline$P_{6}$ & Bijelina & Sarajevo & $\uparrow$ & $\downarrow$ & $\downarrow$ & $\uparrow$ & $\uparrow$ & $\downarrow$ & $\downarrow$ \\
\hline$P_{7}$ & Turin & Incheon, Nagoya & $\downarrow$ & $\uparrow$ & $\downarrow$ & $\downarrow$ & $\downarrow$ & $\uparrow$ & $\uparrow$ \\
\hline \multirow[t]{2}{*}{$P_{8}$} & Zenica & Cluj-Napoca, Skopje & $\uparrow$ & $\downarrow$ & $\downarrow$ & $\downarrow$ & $\downarrow$ & $\downarrow$ & $\downarrow$ \\
\hline & & Average $\left(C_{A V 2}\right)$ & 3.19 & 3.20 & 2.17 & 2.87 & 3.10 & 2.52 & 1.94 \\
\hline
\end{tabular}

Overall, the SDEWES Index can provide the basis for a network of cities that can exchange experiences based on dimension performance. Cities that have opposite outcomes when compared to the average may also provide opportunities for exchanging experiences in relative strengths and weaknesses. For example, the two city pairs in Table 11 that involve Rome $\left(P_{2}\right)$ and Braşov $\left(P_{5}\right)$ from the present sample have opposite outcomes in each 
dimension of the SDEWES Index. In addition, in $D_{7}$, while $R \& D$, innovation and sustainability policy is an area of strength for the city pair involving Rome, it is a weakness for the city pair involving Braşov. Knowledge transfer from the city pair involving Rome to the city pair involving Braşov may initiate city-to-city cooperation.

Some of the city pairs are in relative geographic proximity or in the same country, such as Rome (present sample) and Naples (previous sample) in pair $P_{2}$. Another example is Bijelina (present sample) and Sarajevo (previous sample). Most of the cities, however, are separated by distance but relatively nearer in city function. These include Izola (present sample), Ohrid and Zadar (previous sample) as smaller historical cities $\left(P_{3}\right)$. Another example is Turin (present sample), Incheon and Nagoya (previous samples), which are powerful industrial cities $\left(P_{7}\right)$. These results indicate that city pairs can extend well beyond borders or geographic proximity.

\section{Evaluation of the results in contexts of urban hierarchy and development}

In Figure 11, the results of the SDEWES Index are compared to contextual factors that may exceed the control of cities, such as urban population size (horizontal axis) and the development setting (vertical axis). The latter is assessed based on the Human Development Index (HDI) [184] of the country in which the city is located. The size and colours of the data markers in the bubble chart represent the quartile of the city's performance in the SDEWES Index. In addition, SEE cities that are in the present sample (solid colours) are differentiated from cities in previous samples (patterned lighter colours). The city labels contain pair numbers whenever relevant.

Figure 11 indicates that cities in a particular quartile of performance in the SDEWES Index can have a seemingly diverse background of urban hierarchy and development settings. Cities that perform within quartiles $Q_{4}$ and $Q_{3}$ (blue and green coloured markers), such as Klagenfurt, Pécs, Budapest and Varna, may be given as examples. For this reason, local decision-making choices and strategic approaches have important roles in determining the performance of cities in the SDEWES Index. In this respect, the SDEWES Index can be used to empower cities to search for opportunities to pursue more sustainable pathways for their urban futures while exploring chances to collaborate with other cities to jointly address common urban challenges.

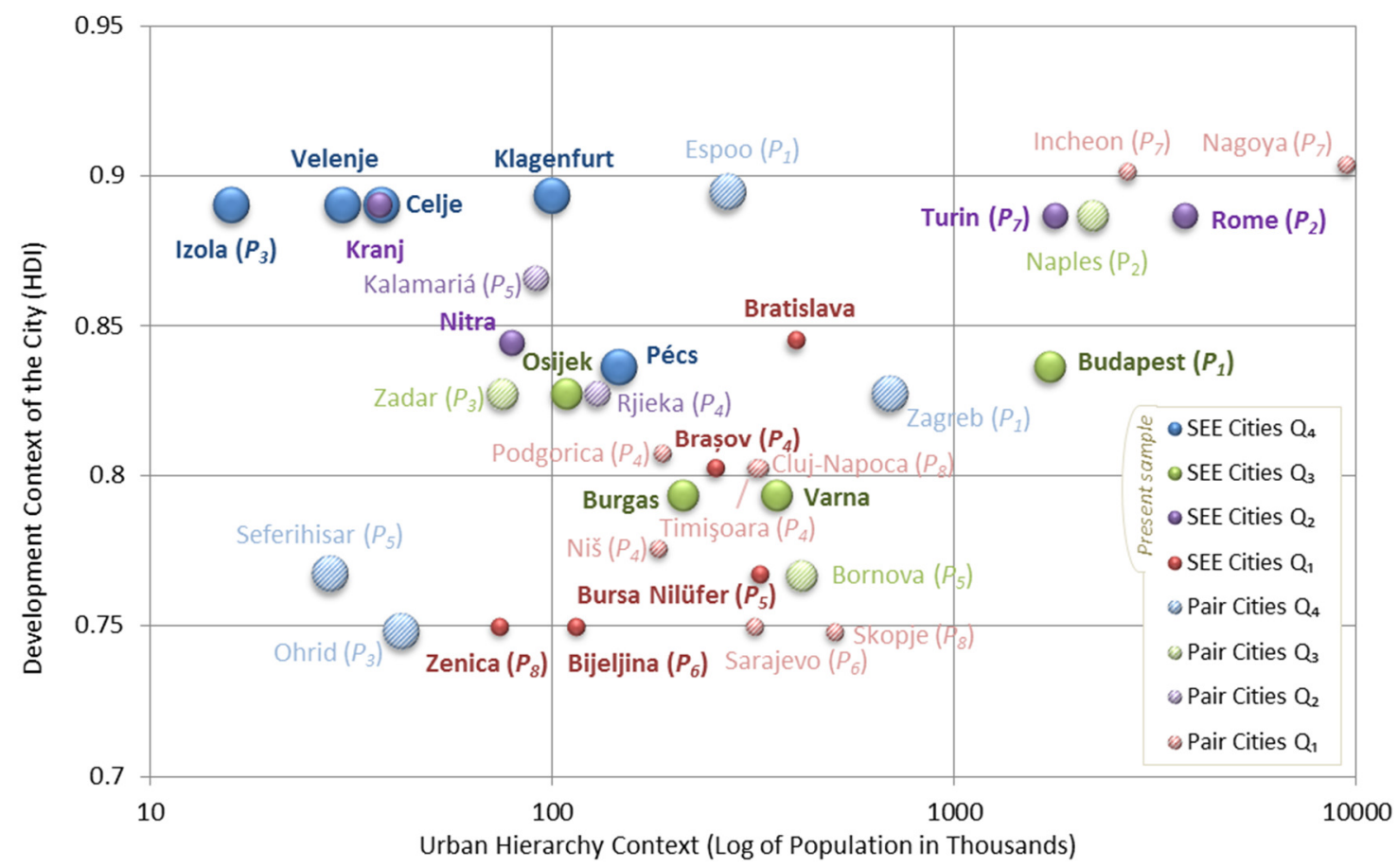

Figure 11. Comparison of results to urban hierarchy and development contexts 


\section{Mapping of a Sustainable Development of Energy, Water and Environment Systems} Future City Network

The synergistic use of the benchmarking tools that are put forth in this paper for the present SEE sample and the identification of city pairs across all other samples provide a spectrum of possible uses of the SDEWES Index in support of more sustainable urban systems. The results of the SDEWES Index for the present SEE sample are also mapped on the spatial dimension as provided in Figure 12. Here, the SEE cities in the sample have different levels of performance based on the dimensions of the SDEWES Index. The existing levels of performance may be improved in the future based on the rapid implementation of actions that are already foreseen in the context of SEAP, SECAPs as well as Sustainable Urban Mobility Plans [185]. In addition, these actions should be supported by newly devised actions based on a unique process of policy learning from other cities. In the time dimension, improvements need to take place to raise the average value of the SDEWES Index for the SEE region and individual cities. The circular inset in Figure 12 provides the current average scores for the cities in the present SEE sample.

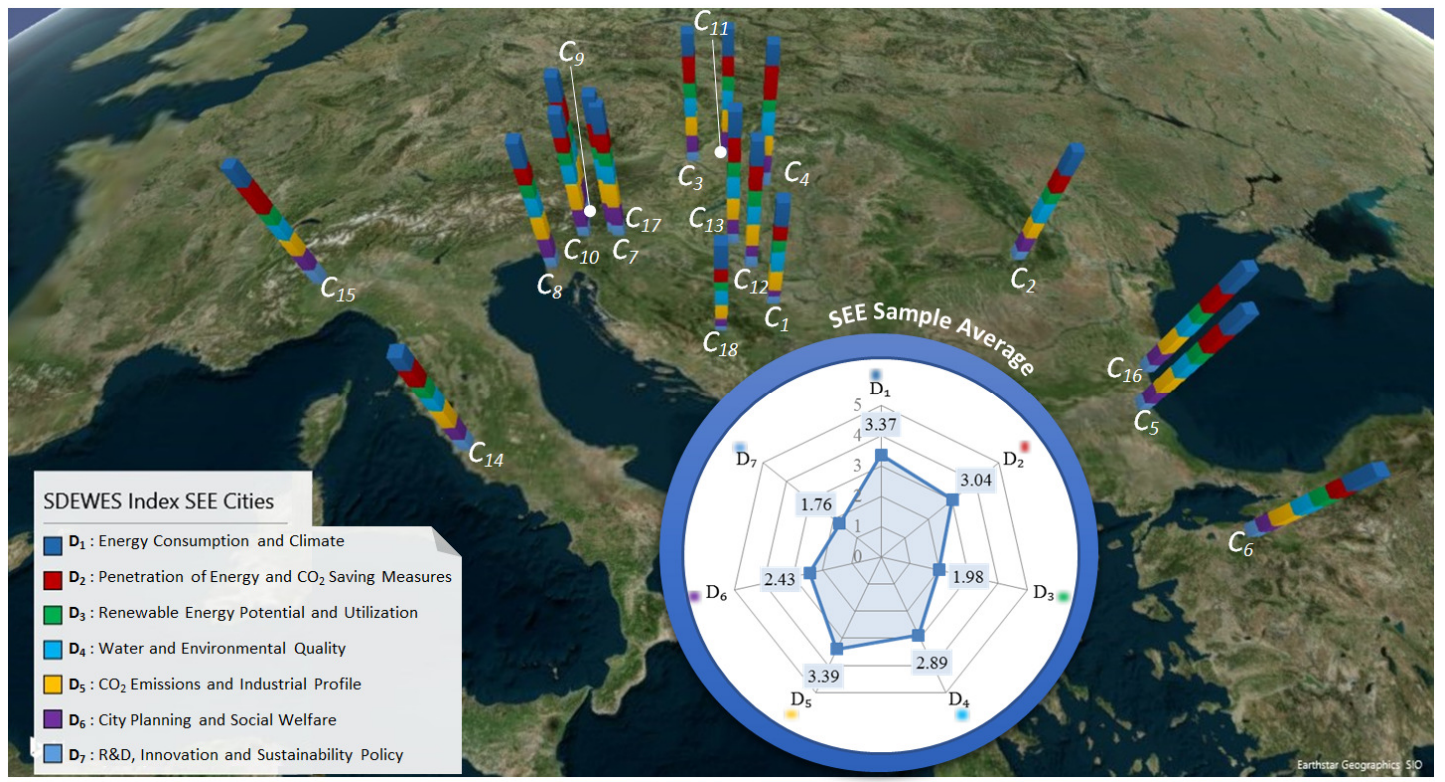

Figure 12. Mapping of the results of the SDEWES Index for the present SEE sample

Table 12 provides an overview of exemplary policy implications for urban systems based on the SDEWES Index. These policy implications also reinforce the necessity for implementing a cross-sectoral approach to attain smarter energy systems [186] at the urban level. Cities provide a vibrant context for realizing the opportunity of increasing efficiencies "by using waste from one system as an input in another" [187]. For example, local maps as developed in the Stratego project in support of heating and cooling plans include those of four cities in the present sample, namely, Braşov, Osijek, Rome and Turin [188]. As summarized in Table 13, the results of these analyses indicate the quantity of waste heat that may be extracted from urban wastewater and the availability of wood and straw resources that are less than $30 \mathrm{~km}$ from the city [188]. Locally available biomass resources must still be considered for use in efficient energy system configurations that may extend to an outlook based on the quality of energy (exergy) [189-191] so that the potential of displacing $\mathrm{CO}_{2}$ emissions is maximized. Carbon capture and storage may also be used to further contribute to halving anthropogenic $\mathrm{CO}_{2}$ emissions every decade [192].

The co-location of energy and water utilities to better benefit from distributed energy generation opportunities and to lower both energy and water requirements is another 
rising trend [193]. In addition, automated demand response in the urban context may extend to wastewater infrastructure, particularly in the sludge processing equipment [194]. Monetary savings from load shifting may be invested into the energy-water infrastructure. In the context of the sharing economy, the sharing of waste heat in an open district heating network, including waste heat of any data centers, is beginning to be promoted by local authorities [195]. The production of hydrogen gas from renewable electricity is also one of the key technologies for diffusing the use of intermittent energy sources [196] and has pilot demonstrations in the urban context [197]. Most importantly, the role of cities in deploying renewable energy as a means of contributing to the need to double zero-carbon shares in the energy system every 5.5 years is paramount for scenarios with a fair chance of compliance with $1.5^{\circ} \mathrm{C}$ targets [192]. Renewable energy solutions and net-zero targets at the district level [198] can support multiple climate mitigation as well as climate adaptation goals. Improvements in urban form can minimize travel distances and reduce climate risks, including through an increase in permeable surfaces [199]. Despite potential changes in precipitation patterns due to global climate change, harvested rainwater and reclaimed water can be effectively maximized to reduce water demand [200].

Table 12. Exemplary policy implications for urban energy, water and environment systems

\begin{tabular}{|c|c|c|c|c|c|c|}
\hline Exemplary cross-sectoral approaches & 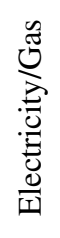 & 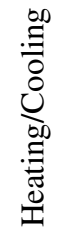 & $\stackrel{\infty}{:}$ & 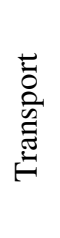 & 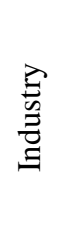 & : \\
\hline Diffusion of urban renewable energy solutions in all sectors & $\checkmark$ & $\checkmark$ & $\checkmark$ & $\checkmark$ & $\checkmark$ & $\checkmark$ \\
\hline Incl. renewable energy and electrofuels in public/private transport & $\checkmark$ & & & $\checkmark$ & & $\checkmark$ \\
\hline Incl. the production of hydrogen gas from renewable energy sources & $\checkmark$ & $\checkmark$ & $\checkmark$ & $\checkmark$ & $\checkmark$ & $\checkmark$ \\
\hline Increased opportunities for sharing waste heat in urban areas & & $\checkmark$ & $\checkmark$ & & $\checkmark$ & $\checkmark$ \\
\hline Demand response, including in wastewater infrastructure & $\checkmark$ & $\checkmark$ & $\checkmark$ & $\checkmark$ & $\checkmark$ & $\checkmark$ \\
\hline Material, energy, and water substitution within urban waste hierarchy & $\checkmark$ & $\checkmark$ & $\checkmark$ & $\checkmark$ & $\checkmark$ & $\checkmark$ \\
\hline Co-location of energy and water utilities for resource exchanges & $\checkmark$ & $\checkmark$ & $\checkmark$ & & & $\checkmark$ \\
\hline Improvements in urban planning to reduce climate risks & $\checkmark$ & $\checkmark$ & $\checkmark$ & $\checkmark$ & $\checkmark$ & $\checkmark$ \\
\hline
\end{tabular}

Table 13. Quantity of waste heat from wastewater and biomass resources based on [188]

\begin{tabular}{ccccc}
\hline Waste heat and biomass availabilities & Rome & Turin & Braşov & Osijek \\
\hline Available heat from sewage water [TJ/year] & 2,430 & 1,767 & 178 & 62 \\
Available wood <30 km [TJ/year] & 454 & 565 & 1,944 & 968 \\
Available straw <30 km [TJ/year] & 1,948 & 2,030 & 785 & 2,351 \\
\hline
\end{tabular}

It is evident that global $\mathrm{CO}_{2}$ emissions must peak no later than the year 2020 and rapidly decrease thereafter to reach net-zero emissions by mid-century [166, 192]. In this planetary necessity, cities are deemed as the leading actors in enabling the ability to "bend the curve" by 2020 [201] that requires a faster pace in mobilizing renewable energy and energy efficiency solutions to attain earlier reductions [202]. This mobilization will also require an integrated perspective for urban energy, water and environment systems without which the ability of cities in climate action will be compromised. The SDEWES Index that is put forth as a benchmarking tool has the potential to support cities in related endeavours and to raise awareness on chances to improve performance. The framework of the SDEWES Index and the results for the city samples has also been communicated with city managers who are responsible for energy 
and/or urban sustainability in their municipalities as well as CoM contact points, receiving positive feedback. Most of the cities were included in any kind of index for the first time and appreciated the chance to be compared to other cities with a common set of indicators in a benchmarking approach. The managers were also active in identifying possible ways to improve performance.

In a potential SDEWES Future City Network, decision-makers in the SEE cities can use the results of the SDEWES Index in four main steps. First, decision-makers should evaluate the overall score and dimension performance of the specific city. Second, possible solutions that are expected to improve the value of more than one indicator at the same time should be considered. Third, decision-makers should identify cities with which to strengthen or initiate collaborative efforts. Throughout these steps, urban decision-makers may further benefit from associated tools, including the SDEWES Index Benchmarking Tool for Policy Learning and the city pairs that are identified based on a search algorithm. Fourth, decision-makers should take action to increase the sustainable development of energy, water and environment systems in their cities. Periodically, the impact of the measures on city performance must be re-evaluated.

\section{CONCLUSIONS}

Urban systems will continue to have critical roles in determining the ability to address the global sustainability challenge by providing innovative urban solutions and approaches. In this context, the SDEWES Index can contribute to triggering action and collaboration in the path towards more integrated energy, water and environment systems for sustainable development. The application of the SDEWES Index to a new sample of $18 \mathrm{SEE}$ cities in this research work increases the opportunities for such policy learning. The results indicate that the top three cities in the sample are Klagenfurt (3.08), Velenje (3.06) and Pécs (3.01), all of which perform above average in multiple dimensions. In addition, cities with similar challenges in and beyond the SEE region based on similar performance patterns are identified to stimulate policy learning.

The results of the SDEWES Index for the 18 cities in the present sample should not provide a static perspective of benchmarking standings since there is a dynamic potential to improve in the future. Even the 5 cities that are positioned in the top $25^{\text {th }}$ percentile $\left(Q_{4}\right)$ of values with a pioneering SDEWES city status in the present sample require future improvements, particularly through the synergy of cross-sector approaches. Such improvements will be possible based on additional investments according to the needs and resources of the city, including human and financial resources. Cities are in the best position to evaluate and act upon such opportunities in light of the benchmarking results, including the diffusion of urban renewable energy solutions.

In a forward-looking perspective, the SDEWES Index, its benchmarking tool and city pairings can be an effective tool to stimulate policy learning in SEE cities towards more sustainable urban systems. In this way, the index contributes to the existing stock of knowledge in aspects of renewable energy, transport, water, and waste in cities based on an integrated benchmarking approach and application. The SDEWES Index can be used to mobilize a network of cities, preferably as a SDEWES Future City Network, to collaborate in realizing the sustainable development of urban systems in the SEE region and beyond. The main steps that decision-makers and urban planners can pursue in using the results of the SDEWES Index are:

- Evaluate the overall score and dimension performance of a specific city: In this first step, decision-makers should evaluate the results of the SDEWES Index for their city. The overall score and dimension performance will provide an integrated perspective for evaluating aspects of energy, water and environment systems in the pursuit of more sustainable urban systems. Strengths in one 
dimension, such as R\&D capabilities, may also be used to support dimensions in which there may be weaknesses to generate new urban solutions. The interactive use of radar charts and bar charts in the SDEWES Index Benchmarking Tool for policy learning will support the city level evaluation process;

- Consider solutions that will improve the value of multiple indicators: The integrated perspective that is put forth by the SDEWES Index aims to support the planning of integrated solutions. Decision-makers and urban planners can build upon this perspective to consider solutions that can address multiple indicators at the same time, particularly those that can curb $\mathrm{CO}_{2}$ emissions and improve environmental quality simultaneously. The opportunity to increase the resource efficiency of the urban system with a combined outlook on the underlying energy, water and environment system [203] will provide the main synergetic approach to allow cities to improve values of the SDEWES Index. These include integrating renewable energy solutions in the urban energy system, utilizing sources of waste heat, diffusing demand response across urban sectors, including in wastewater treatment plants, and enhancing compact urban form;

- Identify cities with which to strengthen or initiate collaborative efforts: Given the urgency for increasing the pace with which cities make progress towards urban systems that are more sustainable, city-to-city collaboration is a necessity rather than an option. At the same time, determining the cities with which to collaborate requires a systematic diffusion of knowledge and benchmarking outcomes. Decision-makers can also refer to the results of the SDEWES Index when a search algorithm is applied to identify city pairs that have the same series of above or below average performances across all dimensions while the benchmarking tool can be used to compare two selected cities;

- Take action to increase the sustainability of development and re-evaluate: The ability of cities to better ensure the intergenerational availability and quality of resources depends upon the success of measures towards more efficient, cleaner, and integrated urban systems. For this reason, cities need to turn any contextual factors into opportunities to make this possible while targeting increases in SDEWES Index values. The monitoring results will be used to re-evaluate the benchmarking results across time.

Future directions of the research work have involved scenario analysis for assessing future opportunities to improve the integration of energy, water and environment systems in the urban context. In this respect, improvements in rank positions or the average city score given the adoption of a related set of measures is assessed. Such improvements are relevant to all cities, including those in the transitioning SDEWES city status. The cities in the solution-seeking or challenged SDEWES city quartile may also shift current trends with relatively stronger effort. The results of the present SEE sample will be useful in analysing the diverse profile of cities in these possible future scenarios in combination with other city samples from around the world. At the same time, existing optimization and planning tools should be applied on a case-by-case basis to evaluate the applicability of possible scenarios at the local level. In this respect, the SDEWES Index may provide a mobilizing mechanism to support the pursuit of cities to strive for more sustainable urban systems as one of the most dynamic contexts for realizing change.

\section{ACKNOWLEDGEMENT}

This paper is based on a manuscript that was presented at the $2^{\text {nd }}$ SEE Conference on SDEWES that was held in Piran, Slovenia during June 15-18, 2016 and further developed for publication in JSDEWES. The Reviewers and Editor are kindly acknowledged for their valuable comments. 


\section{APPENDICES}

\section{Appendix A (supplementary material)}

Tables A1-A8 present data for the sub-indicators of the main indicators of the SDEWES Index.

\section{Appendix B (Sustainable Development of Energy, Water and Environment Systems Index Benchmarking Tool)}

The SDEWES Index Benchmarking Tool is uploaded as a Mendeley Dataset in association with the present manuscript at: http://dx.doi.org/10.17632/cv2bp78gmx.1.

\section{NOMENCLATURE}

C

$D$

$D_{1}$

$D_{2}$

$D_{3}$

$D_{4}$

$D_{5}$

$D_{6}$

$D_{7}$

I

$i$

$\max$

$\min$

$P$

$Q$ specific city in the sample

dimensions of the SDEWES Index $\left(D_{1}-D_{7}\right)$

energy consumption and climate dimension

penetration of energy and $\mathrm{CO}_{2}$ saving measures dimension

renewable energy potential and utilization dimension

water and environmental quality dimension

$\mathrm{CO}_{2}$ emissions and industrial profile dimension

city planning and social welfare dimension

$\mathrm{R} \& \mathrm{D}$, innovation and sustainability policy dimension

normalized values of the indicators in the SDEWES Index

data inputs into the indicators prior to the Min-Max method maximum value among all cities for a given indicator minimum value among all cities for a given indicator specific city pair based on the search algorithm [eq. (4)] quartile of performance in the dimensions or overall index

\section{Greek symbols}

$\alpha$

weights of the dimensions of the SDEWES Index [eq. (1)]

$\begin{array}{ll}\text { Subscripts } & \\ A V & \text { present sample average [used in eqs. (2) and (3)] } \\ A V 2 & \text { overall sample average [used in eq. (4)] } \\ j & \text { number of the city in the sample } \\ x & \text { dimension number, dimensionless } \\ y & \text { indicator number in the dimension }\end{array}$

Abbreviations

$\begin{array}{ll}\text { ACA } & \text { Airport Carbon Accreditation } \\ \text { CDD } & \text { Cooling Degree Day } \\ \text { CHP } & \text { Combined Heat and Power } \\ \text { CoM } & \text { Covenant of Mayors } \\ \text { DH/C } & \text { District Heating and/or Cooling } \\ \text { EEA } & \text { European Environment Agency } \\ \text { GHG } & \text { Greenhouse Gas } \\ \text { HDD } & \text { Heating Degree Day } \\ \text { IEA } & \text { International Energy Agency } \\ \text { IUCN } & \text { International Union for Conservation of Nature } \\ \text { JRC } & \text { Joint Research Center } \\ \text { MSW } & \text { Municipal Solid Waste }\end{array}$




\begin{tabular}{ll}
\hline PM $_{10}$ & Particulate matter up to 10 micrometers in diameter \\
ORC & Organic Rankine Cycle \\
RES & Renewable Energy Systems \\
R\&D & Research and Development \\
SDEWES & Sustainable Development of Energy, Water and Environment Systems \\
SEAP & Sustainable Energy Action Plan(s) \\
SECAP & Sustainable Energy and Climate Action Plan(s) \\
SEE & South East Europe \\
SWERA & Solar and Wind Energy Resource Assessment \\
UN & United Nations \\
WHO & World Health Organization
\end{tabular}

\section{REFERENCES}

1. IEA, Energy Technology Perspectives 2016 - Towards Sustainable Urban Energy Systems, Paris, France, 2016.

2. United Nations Framework Convention on Climate Change, Paris Agreement, 2015.

3. Kılkış, Ş., Composite Index for benchmarking Local Energy Systems of Mediterranean Port Cities, Energy, Vol. 92, No. 3, pp 622-638, 2015, https://doi.org/10.1016/j.energy.2015.06.093

4. SDEWES Centre, http://www.sdewes.org/home.php, [Accessed: 05-February-2017]

5. Kılkış, Ş., Sustainable development of Energy, Water and Environment Systems Index for Southeast European Cities, Journal of Cleaner Production, Vol. 130, pp 222-234, 2016, https://doi.org/10.1016/j.jclepro.2015.07.121

6. Kılkış, Ş., Sustainable development of Energy, Water and Environment Systems (SDEWES) Index for Policy Learning in Cities (in press), International Journal on Innovation and Sustainable Development, pp 1-48, 2018.

7. SDEWES Index, http://www.sdewes.org/sdewes_index.php, [Accessed: 05-February- 2017]

8. Schneider, D., Guzović, Z., Duić, N. and Boldyryev, S., Energy Transition in South East and Central Europe, Thermal Science, Vol. 20, No. 4, pp 11-20, 2016.

9. Duić, N., Krajačić, G. and da Graça Carvalho, M., RenewIslands Methodology for Sustainable Energy and Resource planning for Islands, Renewable and Sustainable Energy Reviews, Vol. 12, No. 4, pp 1032-1062, 2008, https://doi.org/10.1016/j.rser.2006.10.015

10. Krajačić, G., Duić, N., Zmijarević, Z., Vad Mathiesen, B., Vučinić, A. and da Graça Carvalho, M., Planning for a 100\% Independent Energy System based on Smart Energy Storage for integration of Renewables and $\mathrm{CO}_{2}$ Emissions reduction, Applied Thermal Engineering, Vol. 31, No. 13, pp 2073-2083, 2011, https://doi.org/10.1016/j.applthermaleng.2011.03.014

11. Pukšec, T., Vad Mathiesen, B., Novosel, T. and Duić, N., Assessing the Impact of Energy Saving Measures on the Future Energy demand and related GHG (Greenhouse Gas) Emission reduction of Croatia, Energy, Vol. 76, pp 198-209, 2014, https://doi.org/10.1016/j.energy.2014.06.045

12. Komušanac, I., Ćosić, B. and Duić, N., Impact of High Penetration of Wind and Solar PV Generation on the Country Power System Load: The Case Study of Croatia, Applied Energy, Vol. 184, pp 1470-1482, 2016, https://doi.org/10.1016/j.apenergy.2016.06.099

13. Schneider, D. R., Kirac, M. and Hublin, A., Cost-effectiveness of GHG Emission reduction Measures and Energy recovery from Municipal Waste in Croatia, Energy, Vol. 48, No. 1, pp 203-211, 2012, https://doi.org/10.1016/j.energy.2012.02.008

14. Dedineć, A., Markovska, N., Taseska, V., Kanevce, G., Bosevski, T. and Pop-Jordanov, J., The Potential of Renewable Energy Sources for Greenhouse Gases 
Emissions reduction in Macedonia, Thermal Science, Vol. 16, pp 717-728, 2012, https://doi.org/10.2298/TSCI120202128D

15. Dedineć, A., Taseska-Gjorgievska, V., Markovska, N., Obradovic Grncarovska, T., Duić, N., Pop-Jordanov, J. and Taleski, R., Towards Post-2020 Climate Change Regime: Analyses of Various mitigation Scenarios and Contributions for Macedonia, Energy, Vol. 94, pp 124-137, 2016, https://doi.org/10.1016/j.energy.2015.10.085

16. Ćosić, B., Krajačić, G. and Duić, N., A 100\% Renewable Energy System in the Year 2050: The Case of Macedonia, Energy, Vol. 48, No. 1, pp 80-87, 2012, https://doi.org/10.1016/j.energy.2012.06.078

17. Dominković, D., Bačeković, I., Ćosić, B., Krajačić, G., Pukšec, T., Duić, N. and Markovska, N., Zero Carbon Energy System of South East Europe in 2050, Applied Energy, Vol. 184, pp 1517-28, 2016, https://doi.org/10.1016/j.apenergy.2016.03.046

18. Markovska, N., Duić, N., Vad Mathiesen, B., Guzović, Z., Piacentino, Z., Schlör, H. and Lund, H., Addressing the main challenges of Energy Security in the Twenty-first Century - Contributions of the Conferences on Sustainable Development of Energy, Water and Environment Systems, Energy, Vol. 115, Part 3, pp 1504-1512, 2016, https://doi.org/10.1016/j.energy.2016.10.086

19. UN, Sustainable Development Goals: 17 Goals to Transform our World, http:// Www.un.org/sustainabledevelopment/sustainable-development-goals/, [Accessed: 01-May-2016]

20. Mikulandrić, R., Krajačić, G., Duić, N., Khavin, G., Lund, H., Vad Mathiesen, B. and Østergaard, P., Performance analysis of a Hybrid District Heating System: A Case Study of a Small Town in Croatia, Journal of Sustainable Development of Energy, Water and Environment Systems, Vol. 3, No. 3, pp 282-302, 2015, https://doi.org/10.13044/j.sdewes.2015.03.0022

21. Andreu, J., Schneider, D. and Krajačić, G., Evaluation of Integration of Solar Energy into the District Heating System of the City of Velika Gorica, Thermal Science, Vol. 20, No. 4, pp 1049-1060, 2016, https://doi.org/10.2298/TSCI151106106A

22. Ban, M., Krajačić, G., Grozdek, M., Ćurko, T. and Duić, N., The Role of Cool Thermal Energy Storage (CTES) in the integration of Renewable Energy Sources (RES) and Peak Load reduction, Energy, Vol. 48, No. 1, pp 108-117, 2012, https://doi.org/10.1016/j.energy.2012.06.070

23. Kostevšek, A., Klemeš, J. J., Varbanov, P. S., Čuček, L. and Petek, J., Sustainability assessment of the Locally integrated Energy Sectors for a Slovenian Municipality, Journal of Cleaner Production, Vol. 88, pp 83-89, 2015, https://doi.org/10.1016/j.jclepro.2014.04.008

24. Liew, P., Theo, W., Alwi, S., Lim, J., Manan, Z., Klemeš, J. and Varbanov, P., Total Site Heat Integration planning and design for Industrial, Urban and Renewable Systems, Renewable and Sustainable Energy Reviews, Vol. 68, Part 2, pp 964-985, 2017, https://doi.org/10.1016/j.rser.2016.05.086

25. Gašparović, G., Kılkış, Ş., Krajačić, G. and Duić, N., Campus and Community Micro Grids Integration of Building integrated Photovoltaic Renewable Energy Sources Case Study of Split 3 Area, Croatia - Part A, Thermal Science, Vol. 20, No. 4, pp 1135-1145, 2016, https://doi.org/10.2298/TSCI151203080G

26. Ramos, A., Chatzopoulou, M., Guarracino, I., Freeman, J. and Markides, C., Hybrid Photovoltaic-thermal Solar Systems for Combined Heating, Cooling and Power Provision in the Urban Environment (in press), Energy Conversion and Management, 2017, https://doi.org/10.1016/j.enconman.2017.03.024

27. Zhang, H., Baeyens, J. and Degreve, G., The Potential of a Hybrid Power Plant for the Dubrovnik - Neretva County (Southern Croatia), Journal of Sustainable Development of Energy, Water and Environment Systems, Vol. 3, No. 2, pp 174-182, 2015, https://doi.org/10.13044/j.sdewes.2015.03.0014 
28. Kazagić, A., Merzic, A., Redzic, E. and Music, M., Power Utility Generation Portfolio optimization as Function of Specific RES and Decarbonisation Targets EPBiH Case Study, Applied Energy, Vol. 135, pp 694-703, 2014, https://doi.org/10.1016/j.apenergy.2014.09.001

29. Guzović, Z., Rašković, P. and Blatarić, Z., The comparision of a Basic and a Dual-pressure ORC (Organic Rankine Cycle): Geothermal Power Plant Velika Ciglena Case Study, Energy, Vol. 76, pp 175-186, 2014, https://doi.org/10.1016/j.energy.2014.06.005

30. Urbancl, D., Trop, P. and Gorıčanec, D., Geothermal Heat Potential - The Source for Heatıng Greenhouses in Southestern Europe, Thermal Science, Vol. 20, No. 4, pp 1061-1071, 2016, https://doi.org/10.2298/TSCI151129155U

31. Petruschke, P., Gašparović, G., Voll, P., Krajačić G., Duić, N. and Bardow, A., A Hybrid approach for the efficient synthesis of Renewable Energy Systems, Applied Energy, Vol. 135, pp 625-633, 2014, https://doi.org/10.1016/j.apenergy.2014.03.051

32. Novosel, T., Perković, L., Ban, M., Keko, H., Pukšec, T., Krajačić, G. and Duić, N., Agent based modelling and Energy planning - Utilization of MATSim for Transport Energy demand modelling, Energy, Vol. 92, Part 3, pp 466-475, 2015, https://doi.org/10.1016/j.energy.2015.05.091

33. Šare, A., Krajačić, G., Pukšec, T. and Duić, N., The integration of Renewable Energy Sources and Electric Vehicles into the Power System of the Dubrovnik Region, Energy, Sustainability and Society, Vol. 5, No. 27, pp 1-16, 2015, https://doi.org/10.1186/s13705-015-0055-7

34. Prebeg, P., Gašparović, G., Krajačić, G. and Duić, N., Long-term Energy planning of Croatian Power System using Multi-objective Optimization with Focus on Renewable Energy and integration of Electric Vehicles, Applied Energy, Vol. 184, pp 1493-1507, 2016, https://doi.org/10.1016/j.apenergy.2016.03.086

35. Zappone, M., Fiore, S., Genon, G., Venkatesh, G., Brattebø, H. and Meucci, L., Life Cycle Energy and GHG Emission within the Turin Metropolitan Area Urban Water Cycle, Procedia Engineering, Vol. 89, pp 1382-1389, 2014, https://doi.org/10.1016/j.proeng.2014.11.463

36. Polomčić, D., Bajić, D. and Zarić, J., Determining the Groundwater Balance and Radius of Influence using Hydrodynamic modeling: Case Study of the Groundwater Source Šmice in Serbia, Journal of Sustainable Development of Energy, Water and Environment Systems, Vol. 3, No. 3, pp 217-229, 2015, https://doi.org/10.13044/j.sdewes.2015.03.0017

37. Mitrică, B., Mitrică, E., Enciu, P. and Mocanu, I., An approach for forecasting of Public Water Scarcity at the end of the $21^{\text {st }}$ Century, in the Timiş Plain of Romania, Technological Forecasting \& Social Change, Vol. 118, pp 258-269, 2017, https://doi.org/10.1016/j.techfore.2017.02.026

38. Barut, İ., Citiroglu, H., Oruc, M. and Marangoz, A., Determination by Landsat Satellite Imagery to Local Scales in Land and Pollution monitoring: A Case of Buyuk Melen Watershed (Turkey), Journal of Sustainable Development of Energy, Water and Environment Systems, Vol. 3, No. 4, pp 389-404, 2015, https://doi.org/10.13044/j.sdewes.2015.03.0029

39. Nowak, O., Enderle, P. and Varbanov, P., Ways to optimize the Energy Balance of Municipal Wastewater Systems: Lessons learned from Austrian Applications, Journal of Cleaner Production, Vol. 88, pp 125-131, 2015, https://doi.org/10.1016/j.jclepro.2014.08.068

40. Kollmann, R., Neugebauer, G., Kretschmer, F., Truger, B., Kindermann, H., Stoeglehner, G., Ertl, T. and Narodoslawsky, M., Renewable Energy from Wastewater - Practical Aspects of integrating a Wastewater treatment Plant into Local Energy Supply Concepts, Journal of Cleaner Production, Vol. 155, Part 1, pp 119-129, 2017, https://doi.org/10.1016/j.jclepro.2016.08.168 
41. Tomić, T., Ćosić, B. and Schneider, D., Influence of Legislative conditioned changes in Waste management on Economic Viability of MSW-fuelled district heating System - Case study, Thermal Science, Vol. 20, No. 4, pp 1105-1120, 2016, https://doi.org/10.2298/TSCI160212114T

42. Donevska, K., Jovanovski, J., Jovanovski, M. and Pelivanoski, P., Analyses of Environmental impacts of Non-hazardous Regional Landfills in Macedonia, Journal of Sustainable Development of Energy, Water and Environment Systems, Vol. 1, No. 4, pp 281-290, 2013, https://doi.org/10.13044/j.sdewes.2013.01.0021

43. Bošković, M., Josijević, M., Jovičić, N. and Babić, M., Co-Generation Potentials of Municipal Solid Waste Landfills in Serbia, Thermal Science, Vol. 20, No. 4, pp 1271-1281, 2016, https://doi.org/10.2298/TSCI150626063B

44. Stefanović, G., Milutinović, B., Vučićević, B., Denčić-Mihajlov, K. and Turanjanin, V., A comparison of the Analytic Hierarchy Process and the analysis and synthesis of Parameters under Information Deficiency Method for assessing the sustainability of Waste management Scenarios, Journal of Cleaner Production, Vol. 130, pp 155-165, 2016, https://doi.org/10.1016/j.jclepro.2015.12.050

45. Milutinović, B., Stefanović, G., Kyoseva, V., Yordanova, D. and Dombalov, I., Sustainability assessment and comparison of Waste management Systems: The Cities of Sofia and Niš Case Studies, Waste Management and Research, Vol. 34, No. 9, pp 896-904, 2016, https://doi.org/10.1177/0734242X16654755

46. Vučijak, B., Kurtagić, S. and Silajdžić, I., Multicriteria Decision making in selecting best Solid Waste management Scenario: A Municipal Case Study from Bosnia and Herzegovina, Journal of Cleaner Production, Vol. 130, pp 166-174, 2016, https://doi.org/10.1016/j.jclepro.2015.11.030

47. Quynh, L., Hens, L. and Stoyanov, S., Water management in the Framework of Environmental management Systems in Bulgarian Seaports, Physics and Chemistry of the Earth, Vol. 36, No. 5-6, pp 141-149, 2011, https://doi.org/10.1016/j.pce.2010.05.004

48. Đukan, M. and Aralica, Z., Analysing a Bottom-up methodology for developing Communal Biogas Plants in Croatia, Journal of Sustainable Development of Energy, Water and Environment Systems, Vol. 3, No. 4, pp 359-371, 2015, https://doi.org/10.13044/j.sdewes.2015.03.0027

49. Matak, N., Krajačić, G. and Pilato, A., Integrating Sustainable Energy Action Plans for Island Municipalities - Case Study of Korcula, Thermal Science, Vol. 20, No. 4, pp 1037-1048, 2016, https://doi.org/10.2298/TSCI151127109M

50. Fecondo, P. and Moca, G., The ELENA Programme in the Province of Chieti A Public Private Partnership best Practice improving Energy efficiency of Buildings and Public Lighting Systems, Journal of Sustainable Development of Energy, Water and Environment Systems, Vol. 3, No. 3, pp 230-244, 2015, https://doi.org/10.13044/j.sdewes.2015.03.0018

51. Zivkovic, M., Pereverza, K., Pasichnyi, O., Madzarevic, A., Ivezic, D. and Kordas, O., Exploring Scenarios for more Sustainable Heating: The Case of Niš, Serbia, Energy, Vol. 115, Part 3, pp 1758-1770, 2016, https://doi.org/10.1016/j.energy.2016.06.034

52. Salvia, M., Di Leo, S., Nakos, C., Maras, H., Panevski, S., Fülöp, O., Papagianni, S., Tarevska, Z., Čeh, D., Szabó, E. and Bodzsár, B., Creating a Sustainable and Resource efficient Future: A Methodological Toolkit for Municipalities, Renewable and Sustainable Energy Reviews, Vol. 50, pp 480-496, 2015, https://doi.org/10.1016/j.rser.2015.05.027

53. Leo, S. and Salvia, M., Local Strategies and Action Plans towards Resource efficiency in South East Europe, Renewable and Sustainable Energy Reviews, Vol. 68, Part 1, pp 286-305, 2017, https://doi.org/10.1016/j.rser.2016.09.115 
54. Attila Buzási, Will Budapest be a Climate-resilient City? - Adaptation and mitigation challenges and opportunities in development Plans of Budapest, European Journal of Sustainable Development, Vol. 3, No. 4, pp 277-288, 2014, https://doi.org/10.14207/ejsd.2014.v3n4p277

55. Campbell, T., Learning Cities: Knowledge, Capacity and Competitiveness, Habitat International, Vol. 33, No. 2, pp 195-201, 2009, https://doi.org/10.1016/j.habitatint.2008.10.012

56. Senge, P., The Fifth Discipline: The Art and Practice of the Learning Organization, Currency/Doubleday, New York, USA, 2006.

57. Seymoar, N., Mullard, Z. and Winstanley, M., City-To-City Learning, Infrastructure Canada, Vancouver, Canada, 2009.

58. Wells, P., Bristow, G., Nieuwenhuis, P. and Christensen, T., The Role of Academia in Regional Sustainability Initiatives: Wales, Journal of Cleaner Production, Vol. 17, No. 12, pp 1116-1122, 2009, https://doi.org/10.1016/j.jclepro.2008.11.008

59. Luque-Martínez, T. and Muñoz-Leiva, F., City benchmarking: A Methodological proposal referring specifically to Granada, Cities, Vol. 22, No. 6, pp 411-423, 2005, https://doi.org/10.1016/j.cities.2005.07.008

60. Hirvonen-Kantola, S., Ahokangas, P., Iivari, M., Heikkilä, M. and Hentilä, H., Urban development Practices as anticipatory Action learning: Case Arctic Smart City living Laboratory, Procedia Economics and Finance, Vol. 21, pp 337-345, 2015, https://doi.org/10.1016/S2212-5671(15)00185-9

61. March, J., Rationality, Foolishness, and adaptive Intelligence, Strategic Management Journal, Vol. 27, No. 3, pp 201-214, 2006, https://doi.org/10.1002/smj.515

62. Marsden, G., Frick, K., Maya, A. and Deakin, E., How do Cities approach Policy Innovation and Policy learning? A Study of 30 Policies in Northern Europe and North America, Transport Policy, Vol. 18, No. 3, pp 501-512, 2011, https://doi.org/10.1016/j.tranpol.2010.10.006

63. JLL Cities Researcher Center, Benchmarking the Future World of Cities, 2016.

64. Bannerjee, S., Bone, J. and Finger, Y., European Digital City Index - Methodology Report, Nesta Report - ISBN Number: 978-1-84875-153-8, 2016.

65. Murray, S. and Chambers, J., The Safe Cities Index: Assessing Urban Security in the Digital Age, Economist Intelligence Unit, 2015.

66. Afgan, N. and da Graça Carvalho, M., Sustainability assessment of a Hybrid Energy System, Energy Policy, Vol. 36, No. 8, pp 2903-2910, 2008, https://doi.org/10.1016/j.enpol.2008.03.040

67. Lipošćaka, M., Afgan, N., Duić, N. and da Graça Carvalho, M., Sustainability assessment of Cogeneration Sector development in Croatia, Energy, Vol. 31, No. 8, pp 2276-2284, 2006, https://doi.org/10.1016/j.energy.2006.01.024

68. Zidanšek, A., Limbek, M. and Šlaus, I., Contemporary Crises and Sustainability Indicators, Journal of Sustainable Development of Energy, Water and Environment Systems, Vol. 2, No. 2, pp 100-107, 2014, https://doi.org/10.13044/j.sdewes.2014.02.0009

69. Galli, A., Wiedmann, T., Ercin, A., Knoblauch, D., Ewing, B. and Giljum, S., Integrating Ecological, Carbon, and Water Footprint into a Footprint Family of Indicators: Definition and Role in tracking Human Pressure on the Planet, Ecological Indicators, Vol. 16, pp 100-112, 2012, https://doi.org/10.1016/j.ecolind.2011.06.017

70. Baabou, W., Grunewald, N., Ouellet-Plamondon, C., Gressot, M. and Galli, A., The Ecological Footprint of Mediterranean Cities: Awareness Creation and Policy Implications, Environmental Science \& Policy, Vol. 69, pp 94-104, 2017, https://doi.org/10.1016/j.envsci.2016.12.013

71. Ewing, B., Hawkins, T., Wiedmann, T., Galli, A., Ercin, A., Weinzettel, J. and Steen-Olsen, K., Integrating Ecological and Water Footprint accounting in a Multi-regional Input-output Framework, Ecological Indicators, Vol. 23, pp 1-8, 2012, https://doi.org/10.1016/j.ecolind.2012.02.025 
72. De Benedetto, L. and Klemeš, J., The Environmental Performance Strategy Map: An integrated LCA approach to support the Strategic decision-making Process, Journal of Cleaner Production, Vol. 17, No. 10, pp 900-906, 2009, https://doi.org/10.1016/j.jclepro.2009.02.012

73. Tan, S., Yang, J., Yan, J., Lee, C., Hashim, H. and Chen, B., A Holistic Low Carbon City Indicator Framework for Sustainable development, Applied Energy, Vol. 185, Part 2, pp 1919-1930, 2017, https://doi.org/10.1016/j.apenergy.2016.03.041

74. Wang, X., Li, Z., Meng, H. and Wu, J., Identification of Key Energy efficiency drivers through Global City benchmarking: A Data driven approach, Applied Energy, Vol. 190, pp 18-28, 2017, https://doi.org/10.1016/j.apenergy.2016.12.111

75. Hu, M., Wadin, J., Lo, H. and Huang, J., Transformation toward an Eco-city: Lessons from three Asian Cities, Journal of Cleaner Production, Vol. 123, pp 77-87, 2016, https://doi.org/10.1016/j.jclepro.2015.09.033

76. Deilmann, C., Lehmann, I., Reißmann, D. and Hennersdorf, J., Data envelopment analysis of Cities - Investigation of the Ecological and Economic efficiency of Cities using a benchmarking Concept from production management, Ecological Indicators, Vol. 67, pp 798-806, 2016, https://doi.org/10.1016/j.ecolind.2016.03.039

77. Broto, G., Takagi, T., Sprigings, Z., Nishida, Y. and Yarime, M., Innovative Policy practices to advance building Energy efficiency and retrofitting: Approaches, impacts and challenges in ten C40 Cities, Environmental Science \& Policy, Vol. 66, pp 353-365, 2016, https://doi.org/10.1016/j.envsci.2016.06.021

78. Leeuwen van, C., City Blueprints: Baseline assessments of Sustainable Water Management in 11 Cities of the Future, Water Resource Management, Vol. 27, pp 5191-5206, 2013, https://doi.org/10.1007/s11269-013-0462-5

79. Mori, K., Fujii, T., Yamashita, T., Mimura, Y., Uchiyama, Y. and Hayashi, K., Visualization of a City Sustainability Index (CSI): Towards Transdisciplinary approaches involving Multiple Stakeholders, Sustainability, Vol. 7, No. 9, pp 12402-12424, 2015, https://doi.org/10.3390/su70912402

80. Wilson, D., Rodic, L., Cowing, M., Velis, C., Whiteman, A., Scheinberg, A., Vilches, R., Masterson, D., Stretz, J. and Oelz, B., 'Wasteaware' Benchmark Indicators for integrated Sustainable Waste management in Cities, Waste Management, Vol. 35, pp 329-342, 2015, https://doi.org/10.1016/j.wasman.2014.10.006

81. Ahn, J., Cho, S. and Chung, D., Development of a Statistical analysis Model to Benchmark the Energy use Intensity of Subway Stations, Applied Energy, Vol. 179, pp 488-496, 2016, https://doi.org/10.1016/j.apenergy.2016.06.065

82. Tapia, C., Abajo, B., Feliu, E., Mendizabal, M., Martinez, J., Fernández, J., Laburu, T. and Lejarazu, A., Profiling Urban Vulnerabilities to Climate change: An Indicator-based Vulnerability assessment for European Cities, Ecological Indicators, Vol. 78, pp 142-155, 2017, https://doi.org/10.1016/j.ecolind.2017.02.040

83. South East Europe Transnational Cooperation Programme, http://www.southeast-europe. net/hu/, [Accessed: 07-March-2016]

84. Electricity Coordinating Center, http://www.ekc-ltd.com/references/market-coupling-simulator-for-the-south-east-eur opean-region, [Accessed: 12-May-2017]

85. SDEWES, $2^{\text {nd }}$ SEE SDEWES Conference Piran 2016, http://www.piran2016.sdewes.org/, [Accessed: 18-June-2016]

86. Action Plan on Energy Sustainability Bijeljina Municipality (in Bosnian), Bijeljina, Bosnia and Herzegovina, 2011.

87. Agency for Energy Management and Environmental Protection Braşov (ABMEE), Action Plan Sustainable Energy 2010-2020 (in Romanian), 2010.

88. Energy Center Bratislava, Action Plan for Sustainable Energy Development in the City of Bratislava (in Slovak), 2013. 
89. Municipality of Budapest, Budapest City Sustainable Energy Action Plan (SEAP) (in Hungarian), 2010.

90. Municipality of Budapest, Budapest State Environmental Assessment of 2014 (in Hungarian), 2015.

91. Burgas Municipality, Burgas Municipality Strategy for Sustainable Energy Development 2011-2020: Action Plan 2011-2013, 2011.

92. Bursa Nilüfer Municipality, Bursa Nilüfer Municipality Sustainable Energy Action Plan (in Turkish), 2016.

93. Institute Energy Agency of Savinjska, Sustainable Energy Action Plan Municipality of Celje (in Slovenian), 2015.

94. City of Isola, Local Energy Concept for the Period 2014-2024: Municipality of Izola, 2013.

95. Klagenfurt am Wörthersee, Sustainable Energy Action Plan (in German), 2014.

96. Local Energy Agency of Gorenjska Region (LEAG), Sustainable Energy Action Plan (SEAP) for the City Municipality of Kranj, 2014.

97. City of Nitra, Action Plan for Sustainable Energy of Nitra 2020 (in Slovak), 2010.

98. Nitra Monitoring Report 2017 Submission, http://www.covenantofmayors.eu/about/ signatories_en.html?city_id=319\&monitoring, [Accessed: 23-May-2017]

99. Osijek-Baranja City of Osijek City Council, Action Plan for Sustainable Energy Development of the City of Osijek (SEAP) (in Croatian), 2013.

100. Osijek Monitoring Report 2017 Submission (Action), http://www.covenantofmayors.eu/about/signatories_en.html?city_id=3841\&monitori ng, [Accessed: 23-May-2017]

101. South Transdanubian Regional Development Agency, Pécs City Sustainable Energy Action Plan (in Hungarian), 2014.

102. Capital City of Rome, Sustainable Energy Action Plan SEAP for Rome (in Italian), 2011.

103. City of Torino, Turin Action Plan for Energy (TAPE) (in Italian), 2005.

104. City of Torino, Turin Action Plan for Energy Monitoring Report (in Italian), 2015.

105. Monitoring

Overview

Torino, http://www.covenantofmayors.eu/about/signatories_en.html?city_id=269\& monitoring, [Accessed: 23-May-2017]

106. Varna Municipality, Sustainable Energy Development Plan of Varna Municipality 2010-2020 (in Bulgarian), 2010.

107. Institute Energy Agency of Savinjska, Sustainable Energy Action Plan Municipality of Velenje (SEAP), 2011.

108. Economic Development Agency Zenica, Action Plan for Sustainable Energy Development of Zenica Municipality, 2013.

109. CoM, Sustainable Energy Action Plans, http://www.covenantof mayors.eu/actions/ sustainable-energy-action-plans_en.html, [Accessed: 10-March-2016]

110. CoM, Monitoring Action Plans, http://www.covenantofmayors.eu/actions/ monitoring-action-plans_en.html, [Accessed: 19-May-2017]

111. Global Covenant of Mayors for Climate and Energy, http://www.globalcovenantof mayors.org/cities/, [Accessed: 19-May-2017]

112. Kona, A., Melica, G., Koffi, B., Iancu, A., Zancanella, P., Calvete, S., Bertoldi, P., Janssens- Maenhout, G. and Monforti-Ferrario, F., Covenant of Mayors: Greenhouse Gas Emissions Achievements and Projections, JRC Science for Policy Report 2016, EUR 28155 EN, 2016.

113. Covenant of Mayors \& Mayors Adapt Offices, JRC, Sustainable Energy and Climate Action Template, 2016.

114. NREL National Renewable Energy Laboratory NASA Atmospheric Science Data Center Datasets, http://maps.nrel.gov/swera, [Accessed: 28-March-2016] 
115. JRC Photovoltaic Geographical Information System (PVGIS) Incident Global Irradiation for the Chosen http://re.jrc.ec.europa.eu/pvgis/apps4/pvest.php\#, [Accessed: 28-March-2016]

116. SWERA Solar and Wind Energy Research assessment Resource Graphs NASA Atmospheric Science Data Center and NASA/MED Datasets, http://maps.nrel.gov/swera, [Accessed: 28-March-2016]

117. IRENA, Global Atlas for Renewable Energy, http://irena.masdar.ac.ae/\#, [Accessed: 28-March-2016]

118. GENI Global Energy Research Institute, Atlas of Geothermal Resources in Europe Heat-flow http://www.geni.org/globalenergy/library/renewable-energy-resources/world/europe/ geo-europe/index.shtml, [Accessed: 28-March-2016]

119. Carr, G. and Rickwood, C., Water Quality: Development of an Index to assess Country Performance, UNEP GEMS/Water Programme, 2008.

120. Srebotnjak, T., Carr, G., Sherbinin, A. and Rickwood, C., A Global Water Quality Index and Hot-Deck Imputation of Missing Data, Ecological Indicators, Vol. 17, pp 108-119, 2012, https://doi.org/10.1016/j.ecolind.2011.04.023

121. WHO Ambient (Outdoor) Air Pollution in Cities Database 2016, http://www.who.int/ phe/health_topics/outdoorair/databases/cities/en/, [Accessed: 04-April-2016]

122. EEA $\mathrm{PM}_{10}$ Interpolated Maps: Annual Mean Concentrations in Europe, http://www.eea.europa.eu/ themes/air/interactive/pm10, [Accessed: 04-April-2016]

123. GFN Global Footprint Network National Footprint Accounts - National Ecological Footprint and Biocapacity, http://www.footprintnetwork.org, [Accessed: 04-April-2016]

124. ACI Airport Carbon Accreditation Europe, http://www.airportcarbon accreditation.org/airport/participants/europe.html, [Accessed: 04-April-2016]

125. World Bank GDP per Capita PPP International Dollars, http://data.worldbank.org/ indicator/NY.GDP.PCAP.PP.CD, [Accessed: 23-April-2016]

126. Gallup, Behavioral Economics of GDP Growth and Global Wellbeing, Washington D. C., USA, 2010.

127. Eurostat, Educational attainment Statistics, http://ec.europa.eu/eurostat/statisticsexplained/index.php/Educational_attainment_statistics, [Accessed: 23-April-2016]

128.EPO European Patent Office Espacenet, http://www.epo.org/searching/free/espacenet.html, [Accessed: 23-April-2016]

129. Scimago Research Group Journal \& Country Rank, http://www.scimagojr.com/ countrysearch.php, [Accessed: 23-April-2016]

130. IEA Statistics by Country Balances and Electricity and Heat Reports, http://www.iea.org/statistics/statisticssearch/, [Accessed: 05-March-2016]

131. WFN, Water Footprint Statistics, http://waterfootprint.org/en/resources/water-footprint-statistics/, [Accessed: 19-May-2016]

132. Hoekstra, A. and Mekonnen, M., The Water Footprint of Humanity, Proceedings of the National Academy of Sciences, Vol. 109, No. 9, pp 3232-3237, 2012, https://doi.org/10.1073/pnas.1109936109

133. Hoekstra, A., Chapagain, A., Aldaya, M. and Mekonnen, M., Water Footprint assessment Manual: Setting the Global Standard, Earthscan, London, 2011.

134. OECD JRC, Handbook on Constructing Composite Indicators: Methodology and User Guide, OECD Publishing, Paris, France, 2008.

135. CoM, Twinning Programme on adaptation to Climate change: The Main Outcomes in Key Figures!, http://www.eumayors.eu/news_en.html?id_news=811, [Accessed: 18-June-2017]

136. Dijkstra, L. and Poelman, H., Cities in Europe: The New OECD-EC Definition, 2012. 
137. Baklanov, A., Grimmond, C., Carlson, D., Terblanche, D., Tang, X., Bouchet, V., Lee, B., Langendijk, G., Kolli, R. and Hovsepyan, A., From Urban Meteorology, Climate and Environment Research to integrated City Services, Urban Climate (in press), pp 1-12, 2017, https://doi.org/10.1016/j.uclim.2017.05.004

138. Wei, T. and Liu, Y., Estimation of Global rebound Effect caused by Energy efficiency improvement, Energy Economics, Vol. 66, pp 27-34, 2017, https://doi.org/10.1016/j.eneco.2017.05.030

139. Hoornweg, D., Sugar, L. and Gómez, C., Cities and Greenhouse Gas Emissions: moving forward, Environment \& Urbanization, Vol. 23, No. 1, pp 207-227, 2011, https://doi.org/10.1177/0956247810392270

140. ANSI/ASHRAE/IESNA, Standard 90.1-2007 Normative Appendix B: Building Envelope Climate Criteria, Washington D. C., USA, 2007.

141. Lund, H., Werner, S., Wiltshire, R., Svendsen, S., Thorsen, J., Hvelplund, F. and Vad Mathiesen, B., 4th Generation District Heating (4GDH) integrating Smart Thermal Grids into Future Sustainable Energy Systems, Energy, Vol. 68, pp 1-11, 2014, https://doi.org/10.1016/j.energy.2014.02.089

142. Euroheat and Power, Delivering Sustainable Energy to the Heart of the City, https://www.euroheat.org/wp-content/uploads/2016/04/Delivering-sustainable-energ y-to-the-heart-of-the-city-2015.pdf, [Accessed: 19-April-2016]

143. European Commission, Lighting the Cities: Accelerating the Deployment of Innovative Lighting in European Cities, 2013.

144. Budapest Tested the Lighting of the Future, http://www.portfolio.hu/users/elofizetes_ info.php?t=cikk\&i=209431, [Accessed: 19-April-2016]

145. Improving Energy Efficiency in Braşov, http://www.esmap.org/sites/esmap.org/files/ DocumentLibrary/TRACE_Romania_Brasov_Optimized.pdf,

[Accessed: 19-April-2016]

146. Bertoldi, P. and Cuniberti, B., The European GreenLight Programme Efficient Lighting Project Implementation, JRC Publications EUR 24698 EN, 2011.

147. City of Bijeljina, Catalog of Public-Private Partnership Potentials, http://www.sobijeljina. org/ download/ppp_catalog.pdf, [Accessed: 19-April-2016]

148. Borucke, M., Moore, D., Cranston, G., Gracey, K., Katsunori, I., Larson, J., Lazarus, E., Morales, J. C., Wackernagel, M. and Galli, A., Accounting for demand and supply of the Biosphere's Regenerative Capacity: The National Footprint Accounts' underlying Methodology and Framework, Ecological Indicators, Vol. 24, pp 518-533, 2013, https://doi.org/10.1016/j.ecolind.2012.08.005

149. Statistical Yearbook of Republika Srpska, Geographical and Meteorological Data, 2014.

150. Ministry of Foreign Trade and Economic Relations, State of the Environment Report of Bosnia and Herzegovina, Millennium Development Goals Achievement Fund, 2012.

151. European Chemical Industry Council, Landscape of the European Chemical Industry, 2014.

152. EEA/EASA/Eurocontrol, European Aviation Environment Report, 2016.

153. Airport Carbon Accreditation, Airport Carbon Accreditation Annual Report 2015-2016, 2016.

154. Schütz, H. and Bringezu, S., Final Report: Resource Consumption of Germany Indicators and Definitions, Federal Environmental Agency (Umweltbundesamt), Dessau - Roblau Germany, UBA- Texte 08/08 (Translated version), 2008.

155. Rubeis, T., Nardi, I., Paoletti, D., Leonardo, A., Ambrosini, D., Poli, R. and Sfarra, S., Multi-year consumption analysis and Innovative Energy Perspectives: The Case Study of Leonardo da Vinci International Airport of Rome, Energy Conversion and Management, Vol. 128, pp 261-272, 2016, https://doi.org/10.1016/j.enconman.2016.09.076 
156. Rome Airports, Sustainability Report 2015 (in Italian), 2016.

157. Eurostat Urban Audit Database, http://appsso.eurostat.ec.europa.eu/nui/submit ViewTableAction.do, [Accessed: 19-April-2016]

158. IUCN World Database on Protected Areas, http://www.protectedplanet.net/, [Accessed: 02-April-2016]

159. European Climate Adaptation Platform, http://climate-adapt.eea.europa.eu/knowledge/tools/urban-adaptation/climatic-threats /heat-waves/exposure, [Accessed: 19-May-2017]

160. EEA, Urban Atlas, http://www.eea.europa.eu/data-and-maps/data/urban-atlas, [Accessed: 02-April-2016]

161. EEA, Urban Waste Water treatment Maps, http://www.eea.europa.eu/data-and-maps/ uwwtd/interactive-maps/urban-waste-water-treatment-maps-1, [Accessed: 07-May-2016]

162. Eurostat, Municipal Waste generated by Country, http://ec.europa.eu/eurostat/statistics-explained/index.php/Municipal_waste_ statistics, [Accessed: 15-May-2016]

163. Salvia, M., Di Leo, S., Nakos, C., Papagianni, S., Fülöp, O., Csanaky, L., Panevski, S., Tarevska, Z. and Maras, H., Deliverable Report on integrated SEE Methodological Toolkit for Resource efficiency with Final SEE Criteria for assessment, RE-SEEties, 2014.

164. UNESCO Institute for Lifelong Learning, UNESCO Global Network of Learning Cities: Guiding Documents, Hamburg, Germany.

165. Pécsi Tanuló Város-Régió Fórum, City Showcase Session, Pécs, Hungary.

166. IIASA, between $1.5^{\circ} \mathrm{C}$ and $2{ }^{\circ} \mathrm{C}$ - Analyzing the Global Warming Targets, IIASA Policy Brief No. 14, 2016.

167. Saisana, M., A do-it-yourself Guide in Excel for Composite Indicator development, European Commission JRC-COIN, Ispra, Italy, 2012.

168. Ortego, A., Valero, A. and Abadías, A., Environmental Impacts of promoting new Public Transport Systems in Urban Mobility: A Case Study, Journal of Sustainable Development of Energy, Water and Environment Systems, Vol. 5, No. 3, pp 377-395, 2017, https://doi.org/10.13044/j.sdewes.d5.0143

169. European Climate Adaptation Platform, building Railway Transport Resilience to Alpine hazards in Austria, http://climate-adapt.eea.europa.eu/metadata/case-studies/building-railway-transport-r esilience-to-alpine-hazards-in-austria, [Accessed: 18-June-2017]

170. Budapest Power Plant (in Hungarian), http://eng.budapestieromu.hu/page/about-us, [Accessed: 18-June-2017]

171. Iren Energia, The Cogeneration Plants and Turin District Heating System, http://www.irenenergia.it/ChiSiamo/Media/brochure/files/en/Iren_Energia_Telerisca ldamento_Torino_UK.pdf, [Accessed: 12-March-2016]

172. IDM Südtirol, A Biomass Central in Varna, not just a District Heating, https://enertour.bz.it/en/news/centrale-a-biomassa-di-varna-non-solo-teleriscaldamen to, [Accessed: 12-March-2016]

173. Stratego, The Pan-European Thermal Atlas for Romania, http://maps.heatroadmap.eu/maps/30663?preview=true\#, [Accessed: 12-March-2016]

174. Stratego, The Pan-European Thermal Atlas for Croatia, http://maps.heatroadmap.eu/maps/30662?preview=true\#, [Accessed: 12-March-2016]

175. EU Intelligent Energy Program, Effective Open House Days, http://www.greendependent.org/anyagok/Hatekony_Haz_Napok_brossura_2014. pdf, [Accessed: 12-March-2016] 
176. EU, Climate Neutral Urban Districts in Europe, http://www.clue-project.eu/, [Accessed: 12-March-2016]

177. IEA ECBCS Annex 49, Summary Report: Low Exergy Systems for High Performance Buildings and Communities (Schmidt, D. and Torío, H. eds), Fraunhofer - IBP, Stuttgart, Germany, 2011.

178. New Biomass Power Plant officially launched in Pécs, http://www.pannonpower.hu/en/member-companies/pannon-ho-kft/news/hir:211/ new-biomass-power-plant-officially-launched-in-pecs, [Accessed: 12-March-2016]

179. Geothermal District Heating, Nitra Šal'a, http://geodh.eu/project/nitra-sala/, [Accessed: 12-March-2016]

180. Filho, W. L., Ulisses, A., Alves, F., Pace, P., Mifsud, M., Brandli, L., Caeiro, S. and Disterheft, A., Reinvigorating the Sustainable development Research Agenda: The Role of the Sustainable development Goals (SDG), International Journal of Sustainable Development \& World Ecology, pp 1-13, 2017, https://doi.org/10.1080/13504509.2017.1342103

181. Smart Cities \& Communities, https://ec.europa.eu/inea/en/horizon-2020/smart-citiescommunities, [Accessed: 19-May-2016]

182. Grand Hotel Bernardin, http://www.gge.si/portfolio-posts/primer-gh-bernardin, [Accessed: 03-June-2016]

183. EU, Directive 2010/75/EU of the European Parliament and of the Council of 24 November 2010 on Industrial Emissions (Integrated Pollution Prevention and Control) (Recast), Official Journal of the European Union, L 334/17-L 334/119.

184. UNDP, Human Development Index and its Components, http://hdr.undp.org/en/composite/ HDI, [Accessed: 09-March-2017]

185. Eltis, Sustainable Urban Mobility Plans, http://www.eltis.org/mobility-plans, [Accessed: 10-March-2017]

186. Lund, H., Østergaard, P., Connolly, D. and Vad Mathiesen, B., Smart Energy and Smart Energy Systems (in press), Energy, pp 1-10, 2017, https://doi.org/10.1016/j.energy.2017.05.123

187. SDEWES, 12 ${ }^{\text {th }}$ Conference Dubrovnik, http://www.dubrovnik2017.sdewes.org/, [Accessed: 01-June-2017]

188. Stratego, The Pan-European Thermal Atlas Local Maps, http://stratego-project.eu/ local-maps/, [Accessed: 20-May-2017]

189. Kılkış, Ş., Energy System analysis of a Pilot Net-zero Exergy District, Energy Conversion and Management, Vol. 87, pp 1077-1092, 2014, https://doi.org/10.1016/j.enconman.2014.05.014

190. Kılkış, Ş., Exergy transition planning for Net-zero Districts, Energy, Vol. 92, pp 515-531, 2015, http://dx.doi.org/10.1016/j.energy.2015.02.009

191. Björk, F., Kilkis, S. and Molinari, M., Energy Quality Management and Low Energy Architecture, Proceedings of the World Renewable Energy Forum, pp 4558-4564, 2012.

192. Rockström, J., Gaffney, O., Rogelj, J., Meinshausen, M., Nakicenovic, N. and Schellnhuber, H., A Roadmap for Rapid Decarbonization, Science, Vol. 355, No. 6331, pp 1269-1271, 2017, https://doi.org/10.1126/science.aah3443

193. OECD/IEA, Water Energy Nexus, Excerpt from World Energy Outlook 2016, Paris, France, 2016.

194. Aghajanzadeh, A., Wray, C. and McKane, A., Opportunities for automated demand response in California Wastewater Treatment Facilities, Berkeley National Laboratory, Berkeley, California, USA, 2015, https://doi.org/10.2172/1233609

195. City Executive Office of Stockholm, Strategy for a Fossil-fuel free Stockholm by 2040, 2017. 
196. Krajačić, G., Martins, R., Busuttil, A., Duić, N. and Graça Carvalho, M., Hydrogen as an Energy Vector in the Islands' Energy Supply, International Journal of Hydrogen Energy, Vol. 33, No. 4, pp 1091-1103, 2008, https://doi.org/10.1016/j.ijhydene.2007.12.025

197. European Power to Gas, Power-to-gas (demonstration) Projects in Europe, http://www.europeanpowertogas.com/demonstrations, [Accessed: 20-June-2017]

198. Kılkış, Ş., A nearly Net-Zero Exergy District as a Model for Smarter Energy Systems in the Context of Urban Metabolism, Journal of Sustainable Development of Energy, Water and Environment Systems, Vol. 5, No. 1, pp 101-126, 2017, https://doi.org/10.13044/j.sdewes.d5.0136

199. International Water Association, The IWA Principles for Water Wise Cities, 2017.

200. Rojas-Torres, G., Fabricio Nápoles-Rivera, F., Ponce-Ortega, J., Serna-González, M. and El-Halwagi, M., Optimal design of Sustainable Water Systems for Cities involving Future Projections, Computers and Chemical Engineering, Vol. 69, pp 1-15, 2014, https://doi.org/10.1016/j.compchemeng.2014.05.026

201. Rahmstorf, S., Levermann, A., Revill, C. and Harris, V., The Climate turning Point: Our shared Mission for 2020, Potsdam Institute for Climate Impact Research, pp 1-29, 2017.

202. Rogelj, J., Luderer, G., Pietzcker, R., Kriegler, E., Schaeffer, M., Krey, V. and Riahi, K., Energy System transformations for limiting end of-century warming to below $1.5{ }^{\circ} \mathrm{C}$, Nature Climate Change, Vol. 5, pp 519-27, 2015, https://doi.org/10.1038/nclimate2572

203. Urbaniec, K., Mikulčić, H., Rosen, M. and Duić, N., A Holistic approach to Sustainable development of Energy, Water and Environment Systems, Journal of Cleaner Production, Vol. 155, Part 1, pp 1-11, 2017, https://doi.org/10.1016/j.jclepro.2017.01.119

204. General Electric's distributed Power supporting Romania's largest Municipal Gas Engine District Heating investment, http://www.genewsroom.com/press-releases/ge\%E2\%80\%99s-distributed-powersupporting-romania\%E2\%80\%99s-largest-municipal-gas-engine-district, [Accessed: 16-April-2016]

205. KIV, Waste to Energy Celje WtE CHP Plant, http://www.claverton-energy.com/ kiv-biomass-and-waste-to-energy-district-heating-and-power-generation-plants.html, [Accessed: 16-April-2016]

206. Celje Landfill Gas CHP Plant, COGEN Challenge best practices Factsheet Slovenia, http://www.cogeneurope.eu/challenge/Downloadables/Best\%20Practice\%20factshee ts/Slovenia/CC_BPF_CELJE_SI.pdf, [Accessed: 11-July-2016]

207. Cities on Power, Report on Evaluation of the Energy Supply Klagenfurt, http://www.citiesonpower.eu/upload/File/reports/PP3522ReportEnergySupply.pdf, [Accessed: 11-July-2016]

208. Biomass CHP in Osijek and Sisak, http://igr.de/index.php/inf/news/1232-biomasscombined-heat-and-power-plants-in-osijek-and-sisak, [Accessed: 11-July-2016]

209. KTG, Technical Plant, http://ktg-ag.ch/technical-plant/, [Accessed: 11-July-2016]

210. GEO Global Energy Observatory, http://globalenergyobservatory.org/, [Accessed: 05-February-2017]

211. BPIE, Nearly Zero Energy Buildings Definitions Across Europe, http://www. ediltecnico.it/wp-content/uploads/2015/05/BPIE_factsheet_nZEB_definitions_across _ Europe.pdf, [Accessed: 05-February-2017]

212. EU-GUGLE, European Cities serving as Green Urban Gate towards Leadership in Sustainable Energy, http://r2cities.eu/Network/EU-GUGLE.kl\#sthash.truTAjzM.dpuf, [Accessed: 19-May-2016] 
213. IEA EnOB, Net Zero-energy Buildings - Map of International Projects, http://www.enob.info/en/net-zero-energy-buildings/nullenergie-projekte-weltweit/, [Accessed: 07-June-2016]

214. Petrichenko, K., Net-Zero Energy Buildings: Global and Regional Perspectives, Ph.D. Thesis, Central European University, Budapest, Hungary, 2014.

215. D’Agostino, D., Zangheri, P., Cuniberti, B., Paci, D. and Bertoldi, P., Synthesis Report on the National Plans for Nearly Zero Energy Buildings (NZEBs), JRC, Ispra, Italy, 2016.

216. Demographia, Demographia World Urban Areas, $11^{\text {th }}$ Annual Edition: 2015:01, 2015.

217. EEA Percentage of Green Urban Areas in Core Cities, http://www.eea.europa.eu/data-and-maps/figures/percentage-of-green-urban-areas, [Accessed: 11-July-2017]

218. Ramsar Sites Information Service, https://rsis.ramsar.org/, [Accessed: 22-April-2016]

219. JRC Research and Innovation Observatory (RIO), https://rio.jrc.ec.europa.eu/en, [Accessed: 11-July-2016]

220. OECD Main Science and Technology Indicators, http://stats.oecd.org/Index.aspx?DataSet Code =MSTI_PUB, [Accessed: 12-April-2016]

221. UNESCO Institute for Statistics, http://data.un.org/Data.aspx?q=Research+and+ development+expenditure \&d=UNESCO\&f=series\%3AST_SCGERDGDP, [Accessed: 22-April-2016]

222. Scimago Institutions [Accessed: 07-May-2016]

Rankings, http://scimagoir.com/rankings.php, 
APPENDIX A. SUPPLEMENTARY MATERIAL

Table A1. Energy system characteristics based on original compilations ${ }^{\mathrm{a}, \mathrm{b}}$

\begin{tabular}{|c|c|c|c|c|c|}
\hline 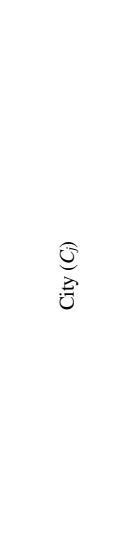 & 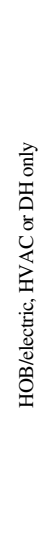 & 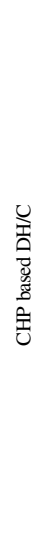 & 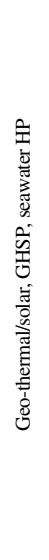 & ith & 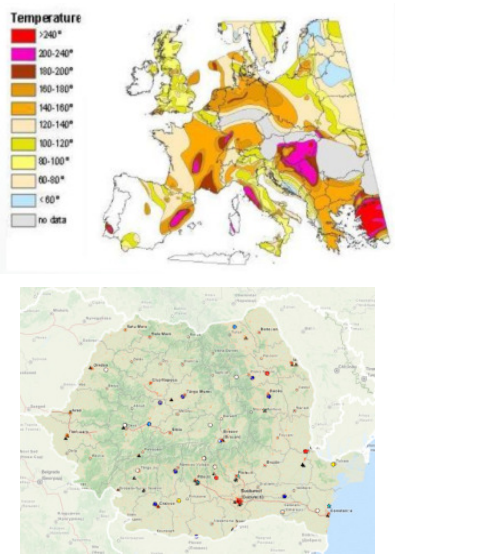 \\
\hline Bijeljina & $\checkmark$ & & $\mathrm{P}$ & \multicolumn{2}{|c|}{ Ongoing project to integrate geothermal energy into the coal based district heating system (BGT1) [86] } \\
\hline Brașov & & $\checkmark$ & & \multicolumn{2}{|c|}{ SEAP measure is realized based on high efficiency CHP with $42 \mathrm{MW}$ of power and $38 \mathrm{MW}$ of heat $[87,204]$} \\
\hline Bratislava & & $\checkmark$ & & \multicolumn{2}{|c|}{ PPC Bratislava CCGT CHP has design capacity of $218 \mathrm{MW}_{\mathrm{c}}$; most buildings are connected to the DH network [88] } \\
\hline Budapest & & $\checkmark$ & & \multicolumn{2}{|c|}{ SEAP measure for high-efficiency CHP with power-to-heat ratio of 0.514 is realized as the largest CHP in Hungary [170] } \\
\hline Burgas & & $\checkmark$ & & \multicolumn{2}{|c|}{ CHP plant with gas reciprocating engines with capacities of $17.82 \mathrm{MW}_{\mathrm{c}}$ and $18.59 \mathrm{MW}_{\mathrm{t}}[91]$} \\
\hline Bursa Nilüfer & $\checkmark$ & & & \multicolumn{2}{|c|}{ Individual heating of buildings dominate; low temperature geothermal energy is used in some touristic facilities [92] } \\
\hline Celje & & $\checkmark$ & & \multicolumn{2}{|c|}{ Municipal waste and sludge is used in CHP with an additional landfill gas unit [205, 206], the General Hospital plans to install CHP [93] } \\
\hline Izola & $\checkmark$ & & $\mathrm{P}$ & \multicolumn{2}{|c|}{ Micro district heating systems are considered as future concepts, including Sea-to-City hydrothermal energy project [94] } \\
\hline Klagenfurt & & $\checkmark$ & & \multicolumn{2}{|c|}{1 CHP fired by oil and $\mathrm{NG}\left(279 \mathrm{GWh}_{\mathrm{t}}\right.$ and $\left.68 \mathrm{GWh}_{\mathrm{c}}\right)$ and $1 \mathrm{CHP}$ supplied by biomass $\left(120 \mathrm{GWh}_{\mathrm{t}}\right.$ and $\left.40 \mathrm{GWh}_{\mathrm{c}}\right)$ [207] } \\
\hline Kranj & $\checkmark$ & $\mathrm{P}$ & & \multicolumn{2}{|c|}{ Planned SEAP measure for the rehabilitation of the DH system with CHP units with power output of $37.2 \mathrm{MW}$ [96] } \\
\hline Nitra & & & $\checkmark$ & \multicolumn{2}{|c|}{ DH system of $20 \mathrm{~km}$ for $24,167 \mathrm{MW}_{\mathrm{t}}$ of installed capacity and $40 \%$ covered by geothermal energy (Temp: $100 / 50^{\circ} \mathrm{C}$ ) [179] } \\
\hline Osijek & & $\checkmark$ & & \multicolumn{2}{|c|}{ TE-TO CHP has power capacity of $89 \mathrm{MW}_{\mathrm{e}}$ and heat supply capacity of $139 \mathrm{MW}_{\mathrm{t}}$ while $3 \mathrm{MW}_{\mathrm{e}}$ and $10 \mathrm{MW}_{\mathrm{t}}$ biomass is planned [208] } \\
\hline Pécs & & $\checkmark$ & & \multicolumn{2}{|c|}{ Heat generating capacity of $70 \mathrm{MW}_{\mathrm{t}}$ and power capacity of $35 \mathrm{MW}_{\mathrm{c}}$ is based on biomass [178] } \\
\hline Rome & $\checkmark$ & $\mathrm{P}$ & & \multicolumn{2}{|c|}{ Planned CHP with DH with bio-fuels up to $50 \%$ of the energy input and estimated potential of saving 25,000 tonnes of $\mathrm{CO}_{2}$ per year [102] } \\
\hline Turin & & $\checkmark$ & & \multicolumn{2}{|c|}{ Three combined-cycle CHP plants for $1,200 \mathrm{MW}_{\mathrm{e}}$ of electrical power and $740 \mathrm{MW}_{\mathrm{t}}$ of thermal power in cogeneration mode [171] } \\
\hline Varna & & $\checkmark$ & & \multicolumn{2}{|c|}{ Biomass boiler from local sawmills plus auxiliary boilers and ORC produce $30 \mathrm{GWh}$ of heat and $5 \mathrm{GWh}$ of electricity [172] } \\
\hline Velenje & & $\checkmark$ & & \multicolumn{2}{|c|}{$77 \%$ share of DH from the coal-lignite thermal power plant in Šoštanj $\left(256 \mathrm{MW}_{\mathrm{c}}\right)$; pilot district cooling absorption system $(970 \mathrm{~kW})$ [107] } \\
\hline Zenica & $\checkmark$ & $\mathrm{P}$ & & \multicolumn{2}{|c|}{$45 \%$ is supplied with DH, $55 \%$ is individual heat system while a modern CHP infrastructure is planned [209] } \\
\hline
\end{tabular}

Table A2. Sub-indicators for nZEB implementations in cities

\begin{tabular}{|c|c|c|c|c|c|}
\hline \multirow[b]{2}{*}{$C_{j}$} & \multirow{2}{*}{$\begin{array}{l}\text { National } \\
\text { nZEB plan }\end{array}$} & \multicolumn{3}{|c|}{ nZEB definition from [211] } & \multirow{2}{*}{$\begin{array}{l}\text { nZEB implementation and/energy plus / } \\
\text { carbon neutral buildings/district targets }\end{array}$} \\
\hline & & $\begin{array}{c}\text { New } \\
\text { buildings }\end{array}$ & $\begin{array}{l}\text { Existing } \\
\text { buildings }\end{array}$ & Minimum RE share & \\
\hline Bijeljina & & & & & N/A \\
\hline Braşov & $\checkmark$ & & & & N/A \\
\hline Bratislava & $\checkmark$ & & & & $\begin{array}{l}\text { EU-GUGLE site for nearly-zero energy } \\
\text { buildings [212] }\end{array}$ \\
\hline Budapest & $\checkmark\left({ }^{*}\right)$ & & & & Passive house residential complex and others \\
\hline Burgas & $\checkmark\left(\left(^{*}\right)\right.$ & $\checkmark$ & & & N/A \\
\hline Bursa Nilüfer & & & & & N/A \\
\hline Celje & $\checkmark$ & & & & N/A \\
\hline Izola & $\checkmark$ & & & & N/A \\
\hline Klagenfurt & $\checkmark$ & $\checkmark$ & $\checkmark$ & Proposed & Villach offices \& apartment [213] \\
\hline Kranj & $\checkmark$ & & & & N/A \\
\hline Nitra & $\checkmark$ & & & & N/A \\
\hline Osijek & $\checkmark$ & & & & $\begin{array}{l}\text { Energy independent home near river Drava } \\
\qquad[214]\end{array}$ \\
\hline Pécs & $\checkmark\left({ }^{*}\right)$ & & & & $\begin{array}{l}\text { Building with Saint-Gobain trophy ranking } \\
\text { [175] }\end{array}$ \\
\hline Rome & $\checkmark$ & & & & $\begin{array}{l}\text { EU-CLUE site for climate neutral urban } \\
\text { districts [212] }\end{array}$ \\
\hline Turin & $\checkmark$ & & & & $\begin{array}{l}\text { EU-CLUE site for climate neutral urban } \\
\text { districts [212] }\end{array}$ \\
\hline Varna & $\checkmark\left(\left(^{*}\right)\right.$ & $\checkmark$ & & & N/A \\
\hline Velenje & $\checkmark$ & & & & N/A \\
\hline Zenica & & & & & N/A \\
\hline
\end{tabular}

${ }^{\mathrm{a}}$ (") To be approved (Bulgaria) or under development (Hungary) [215] 
Table A3. Sub-indicators for the density of the public transport system

\begin{tabular}{|c|c|c|c|c|c|c|c|c|c|c|c|c|}
\hline \multirow[b]{2}{*}{$C_{j}$} & \multirow{2}{*}{$\begin{array}{c}\text { Bus/ } \\
\text { trolley bus } \\
\text { lines }\end{array}$} & \multicolumn{3}{|c|}{ Status of tramway } & \multicolumn{3}{|c|}{ Status of subway/metro } & \multirow{2}{*}{$\begin{array}{c}\text { Total length } \\
\text { urban rail } \\
{[\mathrm{km}]}\end{array}$} & \multirow[b]{2}{*}{$\begin{array}{l}\text { Total urban } \\
\text { area }\left[\mathrm{km}^{2}\right]\end{array}$} & \multirow{2}{*}{$\begin{array}{c}\text { Urban rail } \\
\text { density } \\
{\left[\mathrm{km} / \mathrm{km}^{2}\right]}\end{array}$} & \multirow{2}{*}{$\begin{array}{l}\text { Municipal } \\
\text { bicycle } \\
\text { sharing }\end{array}$} & \multirow[b]{2}{*}{$\begin{array}{l}\text { Overall } \\
\text { score }^{\mathrm{a}}\end{array}$} \\
\hline & & $\begin{array}{l}\text { Stations } \\
\text { (number) }\end{array}$ & Lines & $\begin{array}{l}\text { Length } \\
{[\mathrm{km}]}\end{array}$ & $\begin{array}{c}\text { Stations } \\
\text { (number) }\end{array}$ & Lines & $\begin{array}{l}\text { Length } \\
{[\mathrm{km}]}\end{array}$ & & & & & \\
\hline Bijeljina & $\checkmark$ & & & & & & & 0 & 734 & 0.00 & & 1 \\
\hline Brașov & $\checkmark$ & & & & & & & 0 & 74 & 0.00 & $\checkmark$ & 1 \\
\hline Bratislava & $\checkmark$ & 152 & 8 & 39.6 & & & & 39.6 & 368 & 0.11 & $\checkmark$ & 4 \\
\hline Budapest & $\checkmark$ & 556 & 33 & 156.9 & 52 & 4 & 38.2 & 195.1 & 525 & 0.37 & $\checkmark$ & 5 \\
\hline Burgas & $\checkmark$ & & & & & & & 0 & 254 & 0.00 & $\checkmark$ & 1 \\
\hline $\begin{array}{l}\text { Bursa } \\
\text { Nilüfer }\end{array}$ & $\checkmark$ & 23 & 2 & 9 & 38 & 2 & 39 & 48 & 1036 & 0.05 & & 3 \\
\hline Celje & $\checkmark$ & & & & & & & 0 & 23 & 0.00 & & 1 \\
\hline Izola & $\checkmark$ & & & & & & & 0 & 29 & 0.00 & & 1 \\
\hline Klagenfurt & $\checkmark$ & & & & & & & 0 & 120 & 0.00 & $\checkmark$ & 1 \\
\hline Kranj & $\checkmark$ & & & & & & & 0 & 148 & 0.00 & & 1 \\
\hline Nitra & $\checkmark$ & & & & & & & 0 & 100 & 0.00 & $\checkmark$ & 1 \\
\hline Osijek & $\checkmark$ & 20 & 2 & 12 & & & & 12 & 169 & 0.07 & & 3 \\
\hline Pécs & $\checkmark$ & - & 3 & 16.8 & & & & 16.8 & 163 & 0.10 & & 3 \\
\hline Rome & $\checkmark$ & 192 & 6 & 40 & 73 & 3 & 60 & 100 & 1285 & 0.08 & $\checkmark$ & 4 \\
\hline Turin & $\checkmark$ & - & 11 & 84 & 21 & 1 & 13.2 & 97.2 & 130 & 0.75 & $\checkmark$ & 6 \\
\hline Varna & $\checkmark$ & & & & & & & 0 & 154 & 0.00 & & 1 \\
\hline Velenje & $\checkmark$ & & & & & & & 0 & 13 & 0.00 & $\checkmark$ & 1 \\
\hline Zenica & $\checkmark$ & & & & & & & 0 & 559 & 0.00 & & 1 \\
\hline
\end{tabular}

Table A4. Evaluation of energy intensive industries in the cities ${ }^{\mathrm{a}, \mathrm{b}}$

\begin{tabular}{|c|c|c|c|c|c|c|c|c|c|c|c|c|c|c|c|c|c|}
\hline $\begin{array}{l}\text { Presence of energy intensive } \\
\text { industries in the cities }\end{array}$ & $\begin{array}{l}: \stackrel{\Xi}{0} \\
: \stackrel{\overrightarrow{0}}{0}\end{array}$ & 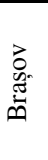 & 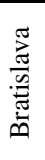 & 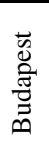 & 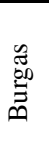 & 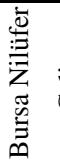 & $\stackrel{\stackrel{0}{0}}{\stackrel{\frac{\pi}{0}}{\circ}}$ & 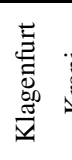 & 节 & 苋 & $\frac{\stackrel{4}{0}}{\frac{\vec{v}}{0}}$ & 这 & 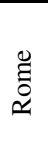 & $\underset{\Xi}{\Xi}$ & $\stackrel{\widetilde{J}}{\tilde{E}}$ & & $\begin{array}{l}\stackrel{\widetilde{U}}{\bar{D}} \\
\text { N }\end{array}$ \\
\hline Basic chemicals and chemical products & & 2 & 1 & 1 & 1 & 1 & 1 & & & 1 & & & 1 & 1 & 1 & & 1 \\
\hline Basic precious and non-ferrous metals & & 1 & & & & & & & & & & & & 1 & & 1 & 1 \\
\hline Cement, lime and plaster industry & & 1 & & & & 1 & & & & & & & & & & & 1 \\
\hline Ceramic products industry & & & & 1 & 1 & 1 & & & & & 1 & 1 & & & & & \\
\hline Iron and steel industry & 1 & & 2 & 1 & & & & & & 1 & & & 1 & 2 & & & 2 \\
\hline Pulp, paper and paperboard industry & & & & & 1 & & 1 & 1 & & & & & & & & & \\
\hline Refined petroleum products industry & & & 2 & & 1 & & & & & & & & & & 1 & & \\
\hline
\end{tabular}

Table A5. Sub-indicators for urban form, green spaces, green corridors and municipal management

\begin{tabular}{|c|c|c|c|c|c|c|c|c|c|c|c|c|c|c|c|c|c|c|}
\hline $\begin{array}{l}\text { Urban form } \\
\text { and municipal management }\end{array}$ & 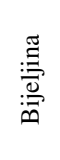 & 总 & 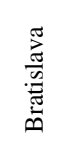 & 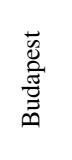 & 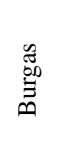 & 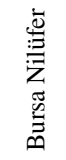 & $\stackrel{\frac{\pi}{\overrightarrow{0}}}{0}$ & 蛋 & 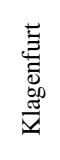 & 氶 & $\stackrel{\widetilde{G}}{\mathrm{Z}}$ & $\frac{\ddot{u}}{: 0}$ & 这 & ڤ్ & 具 & $\stackrel{\widetilde{\Xi}}{\stackrel{\Xi}{\varpi}}$ & $\frac{\frac{0}{7}}{\frac{0}{0}}$ & 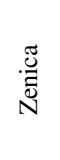 \\
\hline Compact urban form $(1-3)^{\mathrm{a}}$ & 1 & 2 & 2 & 2 & 2 & 2 & 2 & 3 & 2 & 2 & 2 & 2 & 2 & 3 & 2 & 2 & 2 & 1 \\
\hline Monocentric urban form & $\checkmark$ & & & & $\checkmark$ & $\checkmark$ & & $\checkmark$ & & & $\checkmark$ & & & & & $\checkmark$ & & \\
\hline Polycentric urban form & & $\checkmark$ & $\checkmark$ & $\checkmark$ & & & $\checkmark$ & & $\checkmark$ & $\checkmark$ & & $\checkmark$ & $\checkmark$ & $\checkmark$ & $\checkmark$ & & $\checkmark$ & $\checkmark$ \\
\hline Population density $\left[/ \mathrm{km}^{2}\right]$ & 209 & 1,070 & 3,300 & 2,600 & 839 & 9,100 & 2,149 & 554 & 810 & 1,413 & 801 & 638 & 963 & 3,500 & 4,100 & 2,311 & 2,012 & 206 \\
\hline Urban green space (1-3) & $\checkmark$ & $\checkmark$ & $\checkmark$ & $\checkmark$ & $\checkmark$ & $\checkmark$ & $\checkmark$ & $\checkmark$ & & $\checkmark$ & $\checkmark$ & $\checkmark$ & & $\checkmark$ & $\checkmark$ & $\checkmark$ & $\checkmark$ & $\checkmark$ \\
\hline Urban green park intensity ${ }^{\mathrm{c}}$ & 1 & 1 & 2 & 2 & 2 & 2 & 1 & 2 & 1 & 1 & 2 & 1 & 1 & 2 & 2 & 2 & 1 & 1 \\
\hline $\begin{array}{r}\text { Share of impermeable surfaces } \\
\text { in the city [159] }\end{array}$ & - & 63.2 & 50.5 & 62.9 & - & - & - & - & 36.6 & - & 56.9 & 50.3 & - & 44.1 & 62.9 & 50.1 & - & - \\
\hline Green corridor quality (1-3) & 1 & 3 & 3 & 2 & 2 & 2 & 2 & 2 & 3 & 2 & 2 & 2 & 2 & 3 & 2 & 2 & 2 & 1 \\
\hline Reserve & & 2 & 3 & 1 & 2 & & 3 & 2 & 1 & 2 & 2 & 2 & 2 & 4 & 2 & 3 & 2 & \\
\hline RAMSAR $^{\mathrm{d}}$ & & 1 & 2 & 1 & 2 & 2 & & 1 & 2 & 1 & & 1 & 1 & 4 & & & & \\
\hline National park & & 1 & & 1 & & 1 & & & 1 & & & & & & 1 & & & \\
\hline Wastewater management $\mathrm{e}^{\mathrm{e}}$ & N/A & & $\checkmark$ & $\checkmark$ & & N/A & $\checkmark$ & $\checkmark$ & $\checkmark$ & $\checkmark$ & $\checkmark$ & $\checkmark$ & $\checkmark$ & N/A & N/A & & $\checkmark$ & N/A \\
\hline $\begin{array}{c}\text { Municipal waste per capita }[\mathrm{kg}] \\
\text { Waste valorisation } \\
\text { best practices }^{\mathrm{f}}\end{array}$ & 311 & 313 & 329 & 377 & 419 & 400 & $\begin{array}{c}449 \\
\checkmark\end{array}$ & 449 & 560 & 449 & 329 & 393 & 377 & 486 & 486 & 419 & 449 & 311 \\
\hline Average category score & 1.0 & 2.0 & 2.3 & 2.0 & 2.0 & 2.0 & 2.2 & 2.0 & 2.0 & 1.7 & 2.0 & 1.7 & 1.7 & 3.0 & 2.0 & 2.0 & 1.7 & 1.0 \\
\hline
\end{tabular}


Table A6. Sub-indicators for benchmarking R\&D and innovation policy orientation

\begin{tabular}{ccccccccccc}
\hline $\begin{array}{c}\text { R\&D and innovation } \\
\text { policy orientation }^{\mathrm{a}}\end{array}$ & $\mathrm{AT}$ & $\mathrm{BA}$ & $\mathrm{BG}$ & $\mathrm{HR}$ & $\mathrm{HU}$ & $\mathrm{IT}$ & $\mathrm{RO}$ & $\mathrm{SI}$ & $\mathrm{SK}$ & $\mathrm{TR}$ \\
\hline R\&D funding approach score & 3 & 1 & 2 & 3 & 1 & 2 & 2 & 2 & 1 & 3 \\
General(no thematic focus) & $\checkmark$ & $\checkmark$ & $\checkmark$ & $\checkmark$ & $\checkmark$ & $\checkmark$ & $\checkmark$ & $\checkmark$ & $\checkmark$ & $\checkmark$ \\
Thematic focus (calls) & $\checkmark$ & & & $\checkmark$ & & & & & & $\checkmark$ \\
Energy environment priority & $\checkmark$ & & $\checkmark$ & $\checkmark$ & & $\checkmark$ & $\checkmark$ & $\checkmark$ & & $\checkmark$ \\
R\&D expenditure score & 3 & 1 & 2 & 2 & 2 & 2 & 1 & 3 & 2 & 2 \\
GERD/GDP (percentage) & 3.00 & 0.33 & 0.65 & 0.81 & 1.37 & 1.29 & 0.39 & 2.39 & 0.89 & 1.01 \\
\hline Average category score & 3.0 & 1.0 & 2.0 & 2.5 & 1.5 & 2.0 & 1.5 & 2.5 & 1.5 & 2.5 \\
\hline
\end{tabular}

${ }^{a}$ The policy scan involves R\&D funding institutions, support mechanisms, and country reports from JRC [219], OECD [220] and UNESCO [221] statistics

Table A7. Sub-indicators for benchmarking national patents in clean technologies

\begin{tabular}{|c|c|c|c|c|c|c|c|c|c|c|}
\hline $\begin{array}{l}\text { National patents in clean } \\
\text { technologies }\end{array}$ & AT & BA & BG & HR & $\mathrm{HU}$ & IT & RO & SI & SK & TR \\
\hline Total Y02 or Y04 patents & 20,145 & 6 & 704 & 482 & 1,696 & 10,712 & 1,391 & 656 & 605 & 1,012 \\
\hline $\begin{array}{r}\text { Building technologies } \\
\text { (Y02B) }\end{array}$ & 4,104 & 3 & 40 & 81 & 276 & 1,595 & 127 & 137 & 84 & 142 \\
\hline Energy generation (Y02E) & 9,428 & 3 & 577 & 331 & 1,002 & 4,896 & 930 & 421 & 400 & 718 \\
\hline Transportation (Y02T) & 5,743 & 0 & 72 & 42 & 336 & 3,926 & 283 & 70 & 96 & 112 \\
\hline $\begin{array}{r}\text { Capture and storage } \\
(\mathrm{Y} 02 \mathrm{C})\end{array}$ & 402 & 0 & 14 & 14 & 43 & 146 & 31 & 10 & 13 & 27 \\
\hline Smart grid (Y04S) & 468 & 0 & 1 & 14 & 39 & 149 & 20 & 18 & 12 & 13 \\
\hline Y02 or Y04 patent & 2 & 1 & 1 & 1 & 1 & 2 & 1 & 1 & 1 & 1 \\
\hline Percentage of total patents [\%] & 2.17 & 2.78 & 1.89 & 2.82 & 2.73 & 2.23 & 1.97 & 2.11 & 1.95 & 1.63 \\
\hline Total percentage score (1-3) & 2 & 2 & 1 & 2 & 2 & 2 & 1 & 1 & 1 & 1 \\
\hline Average category score & 2.0 & 1.5 & 1.0 & 1.5 & 1.5 & 2.0 & 1.0 & 1.0 & 1.0 & 1.0 \\
\hline
\end{tabular}

Table A8. Number of public, private, and Scimago ranked universities

\begin{tabular}{|c|c|c|c|c|c|c|c|c|c|c|c|c|c|c|c|c|c|c|}
\hline $\begin{array}{c}\text { Universities in } \\
\text { local innovation system }\end{array}$ & 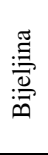 & 总 & 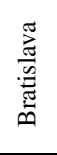 & 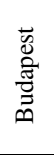 & 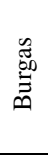 & 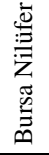 & $\frac{0}{3}$ & 兽 & 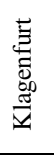 & 吾 & $\stackrel{\frac{\pi}{3}}{2}$ & $\frac{\pi}{\frac{0}{0}}$ & 递 & $\begin{array}{l}\tilde{E} \\
\text { ڤ్ }\end{array}$ & 慁 & $\stackrel{\text { हु }}{>}$ & 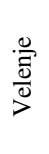 & . \\
\hline Number of universities & 2 & 3 & 8 & 10 & 2 & 3 & 3 & 1 & 2 & 1 & 2 & 1 & 1 & 9 & 3 & 5 & 1 & 1 \\
\hline Public/polytechnic & 0 & 2 & 6 & 7 & 0 & 2 & 0 & 1 & 2 & 0 & 2 & 1 & 1 & 5 & 3 & 4 & 0 & 1 \\
\hline Private universities/colleges & 2 & 1 & 2 & 3 & 2 & 1 & 3 & 0 & 0 & 1 & 0 & 0 & 0 & 4 & 0 & 1 & 1 & 0 \\
\hline Scimago Ranked ${ }^{a}$ & $\checkmark$ & $\checkmark$ & $\checkmark$ & $\checkmark$ & $\checkmark$ & $\checkmark$ & $\checkmark$ & $\checkmark$ & $\checkmark$ & $\checkmark$ & $\checkmark$ & $\checkmark$ & $\checkmark$ & $\checkmark$ & $\checkmark$ & $\checkmark$ & $\checkmark$ & $\checkmark$ \\
\hline Located in the city & 0 & 1 & 3 & 14 & 0 & 1 & 0 & 1 & 1 & 0 & 2 & 1 & 1 & 4 & 2 & 0 & 0 & 0 \\
\hline Located in the country & 1 & 19 & 9 & 23 & 6 & 60 & 6 & 6 & 18 & 6 & 9 & 10 & 23 & 64 & 64 & 6 & 6 & 1 \\
\hline Concentration in city [\%] & 0.0 & 5.3 & 33.3 & 60.9 & 0.0 & 1.7 & 0.0 & 16.7 & 5.6 & 0.0 & 22.2 & 10.0 & 4.3 & 6.3 & 3.1 & 0.0 & 0.0 & 0.0 \\
\hline University weighted score & 2 & 4 & 11 & 24 & 2 & 4 & 3 & 2 & 3 & 1 & 4 & 2 & 2 & 13 & 5 & 5 & 1 & 1 \\
\hline
\end{tabular}

